Jarosław MARCISZ

Bogdan GARBARZ

Tymoteusz TOMCZAK

Aleksandra JANIK

Władysław ZALECKI

Marek BURDEK

Mariusz ADAMCZYK
0000-0002-0001-2197

0000-0002-8090-2738

0000-0001-8339-7792

0000-0002-6601-3205

0000-0003-4551-1886

0000-0002-2556-6460

0000-0002-9120-5487

DOI: 10.32730/imz.2657-747.21.2.2

Sieć Badawcza Łukasiewicz - Instytut Metalurgii Żelaza — Łukasiewicz Research Network - Institute of Ferrous Metallurgy

Lech STARCZEWSKI

0000-0003-3492-2444

Michał GMITRZUK

0000-0002-7490-1093

Robert NYC

Wojskowy Instytut Techniki Pancernej i Samochodowej - Military Institute of Armored and Automotive Technology (WITPiS)

Marcin GOŁUŃSKI

Zakłady Mechaniczne „Tarnów” S.A. — Tarnów Mechanical Works (ZMT)

Krzysztof ŻółKIEWSKI

Paweł LUBOWIECKI

ALCHEMIA S.A.

Marcin SKURCZYŃSKI

Heatmasters Poland Sp. z o.o.

\title{
DEVELOPMENT OF TECHNOLOGY FOR THE PRODUCTION OF LIGHTWEIGHT OBSERVATION AND PROTECTIVE CONTAINER (LOOK) MADE OF NANOSTRUCTURED ULTRA-STRENGTH STEELS
}

\author{
OPRACOWANIE TECHNOLOGII PRODUKCJI LEKKIEGO KONTENERA \\ OBSERWACYJNO-OBRONNEGO (LOOK) ZE STALI NANOSTRUKTURALNYCH \\ ULTRAWYTRZYMAEYCH
}

The article contains results of research and analyses concerning application of nanostructured bainitic steel in the form of plates for manufacturing of armour components. The presented results of examination of microstructure and properties include a wide range of laboratory experiments and industrial tests, which resulted in the achievement of the assumed functional properties. In the period of 2017-2021, a scientific and industrial consortium consisting of Łukasiewicz - Institute of Ferrous Metallurgy (leader); WITPiS, Tarnów Mechanical Works, Alchemia and Heatmasters Poland carried out a project funded by the POIR 04.01.04 programme aimed to develop the design and to manufacture an observation and protective container with a specified resistance to penetration by armour-piercing projectiles and with a lower mass of steel armouring in relation to that currently produced. The aim of the project was achieved by using armour plates made of nanostructured bainitic steel (nanobainitic), which are characterised by high resistance to
Artykut zawiera wyniki badań i analiz dotyczace zastosowania stali nanostrukturalnej bainitycznej $w$ postaci blach arkuszowych do wytwarzania elementów opancerzenia. Przedstawione wyniki badań mikrostruktury i wtaściwości obejmuja szeroki zakres eksperymentów laboratoryjnych $i$ badań przemystowych, $w$ wyniku których osiagnięto zatożone wtaściwości użytkowe. W latach 20172021 konsorcjum naukowo-przemystowe $w$ składzie: Łukasiewicz - Instytut Metalurgii Żelaza (lider), Wojskowy Instytut Techniki Pancernej i Samochodowej (WITPiS), Zaktady Mechaniczne Tarnów S.A. (ZMT), Alchemia S.A. i Heatmasters Poland sp. z o.o. zrealizowato projekt finansowany z programu POIR 04.01.04, którego celem byto opracowanie konstrukcji i wykonanie kontenera obserwacyjno-obronnego o określonej odporności na przebicie pociskami przeciwpancernymi oraz o niższej masie opancerzenia stalowego $w$ odniesieniu do obecnie wytwarzanego. Cel projektu osiagnieto przez zastosowanie blach pancernych ze stali nanostrukturalnej 
high-energy impact concentrated in a small area. The technological tests carried out in the project mainly concerned the development of a new container and industrial technology of armour plates production and their application in the armour of this container. Based on the results of investigation of the semi-industrial scale material, the optimum chemical composition for industrial scale melting and casting was determined. An industrial technology for the production of plates of nano-structured bainitic steel was developed, which includes the following processes: smelting and casting, preliminary heat treatment and ingot hot processing, as well as hot rolling, final heat treatment, and surface treatment. A test batch of the material in the form of $1500 \times 2470 \mathrm{~mm}$ armoured plates was fabricated under industrial conditions. The final result of the project is a container armoured with bainitic nanostructured steel plates with implementation documentation and a technology for producing armoured plates from this steel under the technical and technological conditions of domestic steel manufacturers.

Keywords: nanostructured bainitic steel, production technology, plates, microstructure, mechanical properties, ballistic protection, observation and protective container bainitycznej (nanobainitycznej-NBA), które charakteryzuje wysoka odporność na skoncentrowane na matym obszarze wysokoenergetyczne oddziaływania udarowe. Zrealizowane badania przemystowe $w$ projekcie dotyczyly $w$ głównej mierze opracowania konstrukcji nowego kontenera oraz przemystowej technologii wytwarzania blach pancernych $i$ ich zastosowania w opancerzeniu tego kontenera. Na podstawie wyników badań materiatu wytworzonego $w$ skali pótprzemystowej ustalono optymalny skład chemiczny dla wytopów przemystowych. Opracowano przemystowa technologię wytwarzania blach ze stali nanostrukturalnej bainitycznej, która obejmuje nastepujace procesy: wytapianie i odlewanie, wstępna obróbke cieplna i przetwarzanie wlewków oraz walcowanie na goraco blach i finalna obróbkę cieplna oraz obróbkę powierzchniowa. Wykonano testowa partię materiatu $w$ warunkach przemystowych $w$ postaci pancernych blach arkuszowych o wymiarach $1500 \times 2470 \mathrm{~mm}$. Finalnym rezultatem projektu jest kontener opancerzony za pomoca blach ze stali nanostrukturalnej bainitycznej z dokumentacja wdrożeniowa oraz technologia wytwarzania blach pancernych $z$ tej stali $w$ warunkach techniczno-technologicznych krajowych wytwórców wyrobów stalowych.

Stowa kluczowe: stal bainityczna nanostrukturalna, technologia wytwarzania, blachy, mikrostruktura, wtaściwości mechaniczne, ochrona balistyczna, kontener obserwacyjno-obronny

\section{INTRODUCTION}

Nanostructured bainitic (nanobainitic) steels with a relatively low content of alloying elements - typically in the range of $5-7 \%{ }^{1}$ - allow obtaining ultra-high strength (above $2 \mathrm{GPa}$ ) while maintaining acceptable ductility (elongation and impact strength) for many applications. The first research and theoretical analyses, which indicated the potential application of nano-structured bainitic steels, were carried out by Bhadeshia's team [1-6]. Articles, were also published in the 1990s, covering the subject of nanostructured bainitic steels [7]. The common denominator of the work carried out was the chemical composition of the steel, based on the Fe-C-Si-Mn system and the method of heat treatment, leading to obtaining a carbide-free lathy lower bainite and retained austenite. A number of works concerned the design of new grades of nano-structured bainitic steels in order to improve technological properties and obtain the required set of functional properties. In the field of production technology, much attention was paid to the issue of shortening the time of isothermal transformation, while optimising the temperature of this transformation, e.g. by alloying elements. The temperature and time of isothermal transformation are the key parameters of the technology of manufacturing products made of nanostructured bainitic steels. A separate research problem is the role of retained austenite during the use of nanostructured bainitic steel products. The volume fraction, morphology, distribution, chemical composition and, consequently, thermodynamic and mechanical stability of retained austenite are the main research and technological issues in this field. The first works on nanostructured bainitic steels were carried out for high-carbon high-silicon steel grades [8]. As a result of the applied low temperatures of isothermal annealing $\left(125^{\circ} \mathrm{C}\right)$, a bainite microstructure with an average lath width of $50 \mathrm{~nm}$ was obtained, and the strength reached

\footnotetext{
The content of elements was given in weight \%, unless specified otherwise
}

the value of $2.5 \mathrm{GPa}$. However, attention should be paid to very long isothermal annealing times, amounting to several weeks. In [9] for steel with the chemical composition Fe-0.98\% C-1.46\% Si-1.89\% Mn-1.26\% Cr-0.26\% Mo, annealing temperatures in the range of $125-325^{\circ} \mathrm{C}$ and times respectively from more than 60 days to 1-2 days were used. Based on the analysis of the kinetics of isothermal transformation, it was found that at temperatures from $125^{\circ} \mathrm{C}$ to $200^{\circ} \mathrm{C}$, a bainitic transformation takes place. A thermodynamic model was used in conjunction with the results of research on properties and microstructure to optimise the chemical composition of nanostructured bainitic steel [10]. The investigated material consisted of steels with a content of $0.8-0.7 \% \mathrm{C} ; 1.8-1.9 \% \mathrm{Si} ; 2.2-1.4 \% \mathrm{Mn} ; 1.0-1.4 \% \mathrm{Cr}$; 0.30-0.24\% Mo; $1.31-0.14 \%$ Co; $0.85-0.75 \%$ Al, which, after austenitisation, were isothermally annealed in the temperature range of $200-300^{\circ} \mathrm{C}$. The content of retained austenite was in the range of $2-12 \%$, depending on the temperature and time parameters of the heat treatment. The developed thermodynamic model and the test results confirmed the possibility of obtaining a hardness of $610 \mathrm{HV}$, strength of 1.5-2.0 GPa with an elongation of $8-15 \%$. The issue of improving the impact strength of medium-carbon nanostructured bainitic steel with the following chemical composition: Fe-0.55\% C-1.95\% Mn-1.82\% Si-1.29\% Cr-0.72\% Mo is described in [11]. The authors proposed a two-stage isothermal annealing, with the first stage below the $M_{\mathrm{s}}$ temperature, in order to partially transform austenite into martensite. The second stage of isothermal annealing was carried out at standard temperature, higher than $M_{\mathrm{s}}$. The results of Charpy-V impact strength measurement showed a beneficial effect of the presence of martensite laths, which was tempered during the second annealing stage. Impact strength increased, depending on the test temperature, by approx. $50-70 \%$ in relation to the variants of the standard treatment, consisting in annealing at a constant temperature of isothermal transformation, higher than $M_{\mathrm{s}}$. The authors of [12] conducted research on nanostructured bainitic steels with a wide chemical composition: $\mathrm{C}$ from 
0.49 to $1.00 \%$; Mn from 1.82 to $2.39 \%$; Si from 1.57 to $2.0 \%$; Cr from 0.01 to $1.37 \%$; Co from 0.0 to $1.70 \%$; Mo from 0.27 to $0.80 \%$ with microalloying elements $\mathrm{V}$, Ti and $\mathrm{Al}$. The results of measurement of mechanical properties, microstructure studies and analyses of the manufacturing process of nanostructured bainitic steels, under the conditions of mass production, indicated the following optimal chemical composition: $\quad 0.56 \% \mathrm{C}-2.0 \% \mathrm{Mn}-1.76 \% \mathrm{Si}-1.29 \% \mathrm{Cr}-0.76 \% \mathrm{Mo}$ as well as an isothermal transformation temperature of $225^{\circ} \mathrm{C}$ and time of $60-72$ hours. Tensile strength (TS) of $1.9 \mathrm{GPa}$; yield strength $(Y S)$ of 1.3-1.4 GPa; total elongation (TE) of $15 \%$ and hardness of $600 \mathrm{HV}$ were achieved. The kinetics of isothermal transformation below the $M_{\mathrm{s}}$ temperature are the subject of [13]. The authors showed that after cooling below $M_{\mathrm{s}}$, lamellae (or lath packets) of athermal martensite are formed, the fraction of which increases with lowering temperature. The isothermal resistance below the $M_{\mathrm{s}}$ temperature causes the transition of some austenite to bainite and possibly to isothermal martensite. For the tested bainitic nanostructured steels with a carbon content of $0.55 \%$ and $0.61 \%$, a clear effect of shortening the time to start the isothermal transformation at a temperature below $M_{\mathrm{s}}$ was obtained, compared to the process which takes place at a temperature higher than $M_{\mathrm{s}}$. The results of research on nanostructured bainitic steels and methods of producing armour plates from these steels are presented in [14]. Steels with two chemical compositions were tested: $\mathrm{Fe}-0.80 \% \mathrm{C}-2.01 \% \mathrm{Mn}-1.59 \% \mathrm{Si}-0.24 \% \mathrm{Mo}-1.0 \% \mathrm{Cr}-1.51 \%$ $\mathrm{Co}$ and Fe-0.79\%C-1.98\%Mn-1.56\%Si-0.24\%Mo-1.01\%Cr$1.51 \% \mathrm{Co}-1.01 \% \mathrm{Al}$. The heat treatment parameters were as follows: austenitising temperature $900^{\circ} \mathrm{C}$, cooling in salt and direct isothermal annealing at $250^{\circ} \mathrm{C}$ and $275^{\circ} \mathrm{C}$ for 6 and 12 hours. After annealing at $250^{\circ} \mathrm{C}$ for 12 hours, the material obtained strength of $2.0 \mathrm{GPa}$ and elongation of $15 \%$. The author of the work showed that the austenite deformation of $25 \%$ and $35 \%$ before isothermal transformation slightly slows down the formation of bainite. The specific features of nanostructured bainitic steel, important for the industrial production process, are presented in [15] on the example of the chemical composition of $\mathrm{Fe}-0.55 \% \mathrm{C}$ 1.95\%Mn-1.82\%Si-1.29\%Cr-0.72\%Mo. The authors indicated the features of semi-finished products at individual stages of production: from casting, through plastic working, to final heat treatment - isothermal annealing. They discussed, among others, the tendency of nanostructured bainitic steels to interdendritic segregation during casting and its consequence, microstructure banding in hot rolled products. At Łukasiewicz - Institute of Ferrous Metallurgy, the research on this type of steel began in 2008 in a research and development project financed from structural funds [16]. As a result of the project, the chemical composition and method of producing a grade of nanobainitic steel under the name NANOS-BA ${ }^{\circledR}$ [17] were patented. The next stage of the research was the implementation of the project including the phase of preparation for implementation, for the commercial use of NANOS-BA ${ }^{\circledast}$ steel plates in armour components [18]. The test results quoted on the basis of the literature data and the analysed aspects concerning the production of nanobainitic steel products indicate that there is a potential for the use of this grade in conditions of high-energy impact loads.

In the aspect of the presented test results, in particular the achieved values of strength and plastic properties as well as impact toughness, the project - the results of which are included in this article - included experiments on a laboratory and industrial scale aimed at selecting the parameters for the manufacture of nanobainitic steel products for use in the ballistic shields of the observation and defence container. The armoured observation and protective container is intended for securing and protecting soldiers or officers performing operational tasks during the peacetime as well as during military or stabilisation operations (e.g. at security checkpoints, bases or other strategic facilities, airports, borders, etc.). A container's armour is an important parameter that often determines the possibility of its use. The use of nanostructured steel plates allowed for the improvement of two operational parameters of the container: an increase in the degree of ballistic protection, thus increasing the safety of the crew, and reducing the total weight of the object. Nanobainitic steel is characterised by a high resistance to high-energy impact. The result of this type of interaction may be the perforation of the plate, its cracking or local weakening, contributing to the loss or reduction of the protective capacity. The plates used in the conditions of fire should be characterised by resistance to penetration of certain types of shells, in particular in the conditions of multi-hit fire. The innovative grade of bainitic nanostructured steel is characterised by a high ability to absorb and dissipate impact energy, and the changes in material properties at the point of firing occur in a very small volume, therefore it meets the requirements of the multi-hit firing test.

The scope of work included the design and construction of an innovative container, development of industrial technologies for the production and processing of armour plates made of bainitic nanostructured steel and testing the properties of these plates, including under high-energy dynamic loads. As part of the technological issues related to armour plates, an industrial technology for the production of plates made of nano-structured bainitic steel was developed, which includes the following processes: smelting and casting, preliminary heat treatment and ingot processing, as well as hot rolling, final heat treatment, and surface treatment. During the implementation of the various stages of the project, especially regarding the technology of armour plate production, a number of experiments and tests were carried out, the key of which are described in this article.

\section{THE INVESTIGATED MATERIAL, SCOPE AND METHODOLOGY}

\subsection{LABORATORY MATERIAL}

The investigated material consisted of flat bars made of $150 \times 60 \times 800 \mathrm{~mm}$ flat nanostructured bainitic steel laboratory ingots in four variants of chemical composition. The rolling of flat bars with a nominal thickness of $6,7,8,10$ and $12 \mathrm{~mm}$ was carried out using the LPS/B-IMŻ line with a two-high reversing rolling mill with rolls with a diameter of $550 \mathrm{~mm}$. The flat bars were used to produce samples for dilatometric tests, for microstructure and mechanical properties tests, and for firing tests. The material characteristics of nanostructured steels were determined in terms of: CCT diagrams, mechanical properties, hardness, microstructure, including the content of retained austenite. When developing chemical compositions, particular attention was paid to the following issues related to the functional properties and technology of production of nanostructured steel plates for armour: obtaining high strength (above $2 \mathrm{GPa}$ ) while maintaining good plasticity (elongation 
Table 1. Chemical composition of nanostructured bainitic steel laboratory heats, [weight \%]

Tabela 1. Skład chemiczny wytopów laboratoryjnych stali nanostrukturalnej bainitycznej, [\% masowe]

\begin{tabular}{|c|c|c|c|c|c|c|c|c|}
\hline$\frac{\text { Series }}{\text { heat No. }}$ & $\frac{\text { Requirements }}{\text { type of analysis }}$ & C & Mn & Si & $\mathbf{P}$ & $\mathbf{S}$ & $\mathrm{Cr}$ & Mo \\
\hline \multirow{3}{*}{$\underline{1}$} & $\min$ & 0.60 & 2.00 & 1.60 & 0.000 & 0.000 & 1.30 & 0.50 \\
\hline & $\max$ & 0.64 & 2.20 & 1.75 & 0.010 & 0.010 & 1.40 & 0.60 \\
\hline & recommended & 0.62 & 2.10 & 1.65 & & & 1.35 & 0.55 \\
\hline \multirow{2}{*}{617} & melting & 0.63 & 2.10 & 1.68 & 0.006 & 0.011 & 1.38 & 0.56 \\
\hline & control & 0.65 & 2.05 & 1.75 & 0.005 & 0.013 & 1.34 & 0.57 \\
\hline \multirow{3}{*}{$\underline{2}$} & $\min$ & 0.56 & 1.65 & 1.50 & 0.000 & 0.000 & 1.25 & 0.40 \\
\hline & $\max$ & 0.60 & 1.80 & 1.65 & 0.010 & 0.010 & 1.40 & 0.50 \\
\hline & recommended & 0.58 & 1.70 & 1.55 & & & 1.35 & 0.45 \\
\hline \multirow{2}{*}{640} & melting & 0.58 & 1.69 & 1.57 & 0.009 & 0.008 & 1.35 & 0.44 \\
\hline & control & 0.60 & 1.67 & 1.61 & 0.008 & 0.011 & 1.33 & 0.45 \\
\hline \multirow{3}{*}{$\underline{3}$} & $\min$ & 0.50 & 2.00 & 1.65 & 0.000 & 0.000 & 1.45 & 0.70 \\
\hline & $\max$ & 0.54 & 2.20 & 1.75 & 0.010 & 0.010 & 1.55 & 0.80 \\
\hline & recommended & 0.52 & 2.10 & 1.70 & & & 1.50 & 0.75 \\
\hline \multirow{2}{*}{641} & melting & 0.53 & 2.10 & 1.70 & 0.009 & 0.010 & 1.49 & 0.75 \\
\hline & control & 0.57 & 2.18 & 1.71 & 0.008 & 0.011 & 1.48 & 0.77 \\
\hline \multirow{3}{*}{$\underline{4}$} & $\min$ & 0.48 & 2.00 & 1.70 & 0.000 & 0.000 & 1.45 & 0.70 \\
\hline & $\max$ & 0.52 & 2.20 & 1.80 & 0.010 & 0.010 & 1.55 & 0.80 \\
\hline & recommended & 0.50 & 2.10 & 1.80 & & & 1.50 & 0.75 \\
\hline \multirow{2}{*}{648} & melting & 0.51 & 2.10 & 1.75 & 0.006 & 0.008 & 1.48 & 0.73 \\
\hline & control & 0.50 & 2.12 & 1.84 & 0.004 & 0.009 & 1.51 & 0.81 \\
\hline
\end{tabular}

in static tensile test of at least $12 \%$ ) and fracture toughness (impact strength $\mathrm{KV}$ at room temperature of at least $12 \mathrm{~J}$ for $10 \times 10 \times 55 \mathrm{~mm}$ sample); the possibility of cooling plates with a thickness in the range of 6-8 $\mathrm{mm}$ from austenitising temperature to isothermal transformation temperature, freely in the air or in an accelerated manner with the use of fans, obtaining the lowest possible alloying content (Mn, $\mathrm{Si}, \mathrm{Cr}$ and $\mathrm{Mo}$ ) and striving to shorten the time of isothermal heating as much as possible. It is not always possible to meet all the mentioned conditions simultaneously. The key criteria for selecting the material were the results of the mechanical properties tests and the firing tests. Table 1 presents the chemical composition of nanobainitic steel laboratory heats. Laboratory ingots made using the method of vacuum melting and casting met the requirements for the content of basic elements decisive for obtaining the final functional properties. The ingots also met the requirements for surface quality, shrinkage cavity size and extent, total weight and geometry (dimensions and shape) and were intended for further processing. Homogenisation heat treatment was not used.

\subsection{INDUSTRIAL MATERIAL}

\subsubsection{Nanobainitic steel smelting and casting}

Table 2 presents guidelines for the production of industrial heats regarding the chemical composition, and Table 3 presents the results of the chemical composition analysis of the test heats. In the industrial process involving electric

Table 2. Guidelines for the chemical composition of industrial heats of nano-structured bainitic steel, [weight \%] Tabela 2. Wytyczne w zakresie składu chemicznego wytopów przemysłowych stali nanostrukturalnej bainitycznej, [\% masowe]

\begin{tabular}{|c|c|c|c|c|c|c|c|c|c|c|c|c|}
\hline \multicolumn{2}{|c|}{$\begin{array}{c}\text { Steel grade } \\
\text { identification }\end{array}$} & C & Mn & Si & $\mathbf{P}$ & $\mathbf{S}$ & $\mathbf{C r}$ & $\mathrm{Cu}$ & Mo & $\mathbf{A} \mathbf{l}_{\text {met }}$ & $\begin{array}{c}\mathbf{N} \\
\text { ppm }\end{array}$ & $\begin{array}{c}\text { O } \\
\text { ppm }\end{array}$ \\
\hline \multirow{3}{*}{$\mathrm{P} 1$} & $\min$ & 0.58 & 1.65 & 1.60 & - & - & 1.35 & - & 0.55 & 0.015 & $\max$ & $\max$ \\
\hline & $\max$ & 0.62 & 1.75 & 1.70 & 0.010 & 0.010 & 1.45 & 0.15 & 0.65 & 0.025 & 60 & 25 \\
\hline & Aim & 0.60 & 1.70 & 1.65 & * & * & 1.40 & * & 0.60 & 0.020 & $*$ & * \\
\hline \multirow{3}{*}{ P2 } & $\min$ & 0.54 & 1.80 & 1.70 & - & - & 1.45 & - & 0.70 & 0.015 & $\max$ & $\max$ \\
\hline & $\max$ & 0.58 & 1.90 & 1.80 & 0.010 & 0.010 & 1.55 & 0.15 & 0.80 & 0.025 & 60 & 25 \\
\hline & Aim & 0.56 & 1.85 & 1.75 & * & * & 1.50 & * & 0.75 & 0.020 & * & * \\
\hline
\end{tabular}

*) the lowest possible content in the applied technological process 
Table 3. Chemical composition of industrial test heats P1-882917 and P2-883040. The heat analysis was carried out at Alchemia and Łukasiewicz - IMż, [weight \%]

Tabela 3. Skład chemiczny przemysłowych wytopów badawczych P1-882917 i P2-883040. Analizę wytopową wykonano w Alchemii oraz w Lukasiewicz - IMż, [\% masowe]

\begin{tabular}{|c|c|c|c|c|c|c|c|c|c|c|c|c|}
\hline $\begin{array}{c}\text { Heat No. } \\
\text { identification }\end{array}$ & $\begin{array}{c}\text { Analysed } \\
\text { by }\end{array}$ & C & Mn & Si & $\mathbf{P}$ & $\mathbf{S}$ & $\mathrm{Cr}$ & Mo & Al & $\mathrm{Cu}$ & $\begin{array}{c}\text { N } \\
\text { ppm }\end{array}$ & $\begin{array}{c}0 \\
\text { ppm }\end{array}$ \\
\hline \multirow{3}{*}{$\begin{array}{c}882917 \\
\text { P1 }\end{array}$} & $\mathrm{ALCH}$ & 0.60 & 1.69 & 1.65 & 0.010 & 0.004 & 1.41 & 0.59 & 0.023 & 0.07 & 32 & 9 \\
\hline & Ł-IMŻ 1 & 0.59 & 1.70 & 1.60 & 0.012 & 0.004 & 1.40 & 0.59 & 0.022 & 0.07 & 27 & 17 \\
\hline & Ł-IMŻ 2 & 0.59 & 1.69 & 1.60 & 0.012 & 0.004 & 1.40 & 0.59 & 0.022 & 0.07 & 24 & 7 \\
\hline \multirow{3}{*}{$\begin{array}{c}883040 \\
\text { P2 }\end{array}$} & $\mathrm{ALCH}$ & 0.56 & 1.85 & 1.75 & 0.013 & 0.003 & 1.49 & 0.74 & 0.026 & 0.09 & 23 & 16 \\
\hline & Ł-IMŻ 1 & 0.55 & 1.81 & 1.74 & 0.017 & 0.004 & 1.46 & 0.75 & 0.025 & 0.093 & 26 & 10 \\
\hline & Ł-IMŻ 2 & 0.56 & 1.82 & 1.74 & 0.017 & 0.004 & 1.47 & 0.75 & 0.025 & 0.093 & 28 & 11 \\
\hline
\end{tabular}

arc furnace (EAF) smelting, secondary vacuum furnace treatment (VAD) and uphill casting, the main elements (C, Mn, Si, Cr, Mo) were at the correct level, and only the phosphorus content was slightly exceeded. A material in the form of ingots from two nanostructured bainitic steel heats were produced. While cooling after casting, the ingots, after reaching the temperature of approx. $700^{\circ} \mathrm{C}$, were placed in a heating furnace and subjected to softening and annealing at $720^{\circ} \mathrm{C}$. A low hardness of approx. $260 \mathrm{HB}$ was achieved on the surface. After soft and stress-relief annealing, the material was intended for forging into flat slabs.

\subsubsection{Nanobainitic steel ingot forging}

The ingots were forged into $120 \times 800 \times 1350 \mathrm{~mm}$ slabs which constituted the feedstock for the rolling mills. The ingots were heated with the furnace to $1200^{\circ} \mathrm{C}$, and then held at this temperature for 30 hours in order to reduce the degree of segregation. During forging, the temperature range of $1200-900^{\circ} \mathrm{C}$ was used with an acceptable temperature drop in the area of the corners and the surface layer to approx. $850^{\circ} \mathrm{C}$. The slabs were transported to the furnace immediately after forging and cooled down with the furnace to ambient temperature. Then, the slabs were subject to the process of cold straightening. No surface defects were found that could significantly affect the further process of plastic working using hot rolling. The slabs met the requirements for geometry and surface quality for further processing. In the field of the preliminary heat treatment process and hot forging of bainitic nanostructured steel at ALCHEMIA S.A. the highest level of technological readiness was achieved.

\subsubsection{Hot rolling of nanobainitic steel plates}

Industrial trials of hot rolling of nanobainitic plates was carried out, as a result of which $1500 \times 2470 \mathrm{~mm}$ plates with a thickness in the range of $6-9 \mathrm{~mm}$ were produced. The

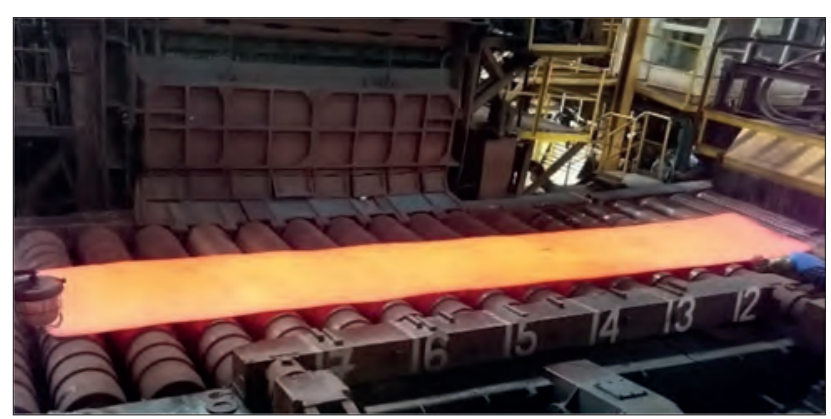

Fig. 1. Photograph of a strip during hot rolling

Rys. 1. Fotografia pasma $w$ trakcie walcowania na gorąco plates, immediately after rolling and cooling in the air to the temperature on the surface of approx. $200-300^{\circ} \mathrm{C}$, were stacked and cooled down to ambient temperature. Due to the high hardenability of the steel resulting in a hardness of $60 \mathrm{HRC}$ (approx. $735 \mathrm{HV}$ ), the material in this state could not be cut with guillotine shears. A sample was taken from $6 \mathrm{~mm}$ thick plates from heat P1 after hot rolling for preliminary material tests. In order to reduce hardness, the plates were subjected to soft annealing at $680^{\circ} \mathrm{C}$. After softening, the hardness was $350 \mathrm{HB}$. Fig. 1 presents photographs of the plates during rolling.

\subsubsection{Final heat treatment of plates in industrial conditions}

Heat treatment of nanostructured bainitic steels is a key production stage. The process consists of several immediately consecutive stages: heating, austenitising, controlled cooling and isothermal annealing, as well as cooling to ambient temperature. Preliminary cycles of heat treatment were performed using the following parameters of the individual stages: austenitising at $950^{\circ} \mathrm{C}$, controlled cooling with air blowing to cool the plates at a rate of min. $1^{\circ} \mathrm{C} / \mathrm{s}$ and isothermal annealing in the temperature range of $210-225^{\circ} \mathrm{C}$. As a result of examining the microstructure and mechanical properties as well as firing tests carried out on steel plates, the following parameters of the final heat treatment were determined: austenitising temperature of $950^{\circ} \mathrm{C}$ and time of 30 minutes, accelerated cooling with the use of two mobile fans and isothermal annealing immediately after cooling at two temperatures at $225^{\circ} \mathrm{C}$ for 12 hours and then at $210^{\circ} \mathrm{C}$ for a total of both temperatures - including the time needed to reach $210^{\circ} \mathrm{C}$ - for 96 hours (Fig. 2). The time of cooling from higher to lower temperature was approx. 1 hour. Plates with a thickness of 7-9 mm were produced in such manner. "Witness" tensile samples were used in each research bundle (cycle). A research batch of plates was produced and components of the container armour were prepared in the form of plate formats with the assumed functional properties, dimensions and surface quality.

\subsection{TESTING METHODS}

The microstructure of nanobainitic steels was examined using a light microscope (LM), scanning electron microscope (SEM) and transmission electron microscope (TEM). The EBSD method in SEM was used to investigate the morphology, arrangement, size distribution and volume fraction of blocky retained austenite. The content of retained austenite was also measured with an X-ray diffractometer 

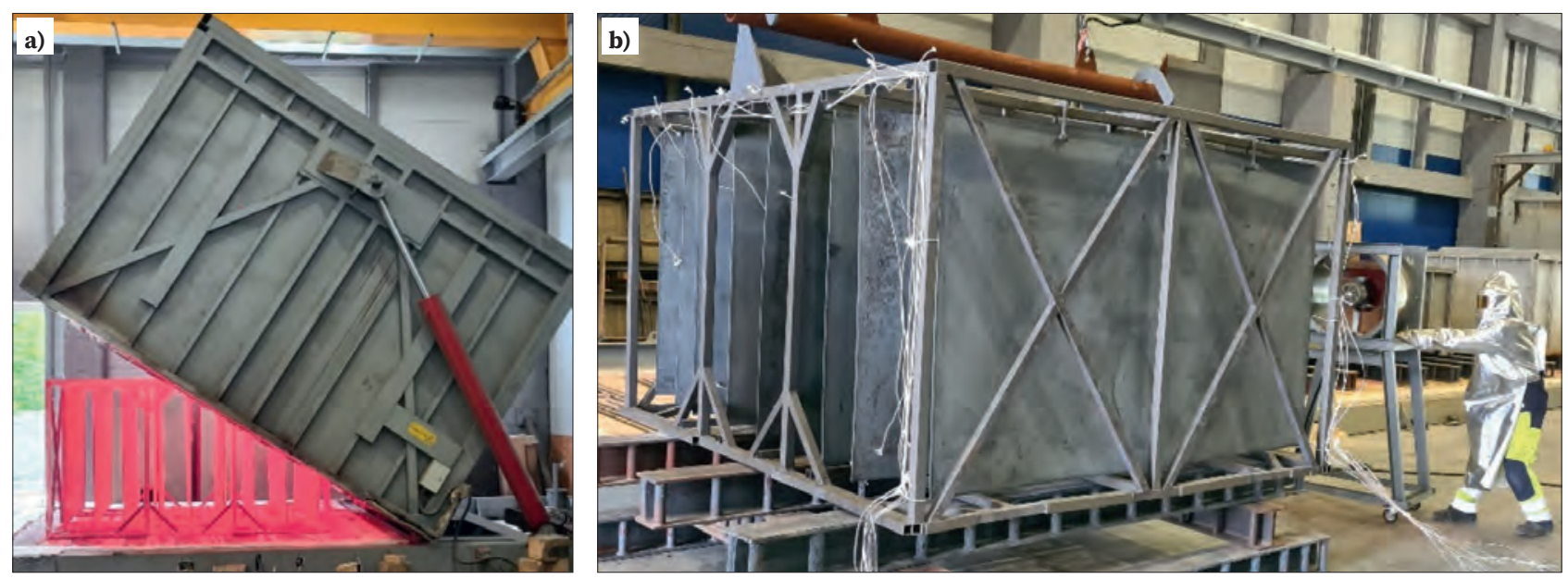

Fig. 2. Photograph of plates during austenitising (a) and controlled cooling (b)

Rys. 2. Fotografia blach podczas austenityzowania (a) i regulowanego chłodzenia (b)

using filtered cobalt radiation in the configuration with a Pixcel detector. The morphology of retained austenite in the form of laths was studied using TEM. A static tensile test was used to determine mechanical properties (TS, YS, TE). Charpy-V impact strength was measured on $7.5 \times 10 \times 55 \mathrm{~mm}$ samples at -60 to $+40^{\circ} \mathrm{C}$. The nominal height of the sample below the notch was $8 \mathrm{~mm}$. The hardness measurement was carried out using the HRC, HV and HB methods. Additionally, uniaxial compression tests of cylindrical samples with strain rates up to $100 \mathrm{~s}^{-1}$ were carried out using a Gleeble 3800 GTC simulator. The firing tests for the plates were carried out at WITPiS with the use of ballistic barrels. The barrel's quadrant elevation was $0^{\circ}$ and $30^{\circ}$. The shell impact velocity was measured using a PVM-2008/21 chronograph. A witness plate, i.e. a $0.5 \mathrm{~mm}$ thick aluminium plate, was placed behind the sample at a distance of $150 \mathrm{~mm}$. The firing was carried out at ambient temperature, without the samples' temperature being controlled, and the number of shots was determined during the tests depending on the subsequent test results.

\section{RESULTS OF INVESTIGATION FOR LABORATORY MATERIAL}

\subsection{RESULTS OF MICROSTRUCTURE EXAMINATION AND MEASUREMENT OF MECHANICAL PROPERTIES}

In the first stage of testing the laboratory material, dilatometric measurement and heat treatment tests were carried out in order to determine the possibility of obtaining the desired mechanical properties. The dilatometric tests included the determination of characteristic temperatures, the development of a part of the CCT phase diagrams (an example for the laboratory melt is presented in Fig. 3) and the final heat treatment including austenitisation, controlled cooling and isothermal annealing in the temperature range of $180-240^{\circ} \mathrm{C}$ for up to 120 hours. Under the conditions of laboratory heat treatment of tensile samples, the required degree of similarity to the industrial research planned at a later stage regarding the final heat treat-

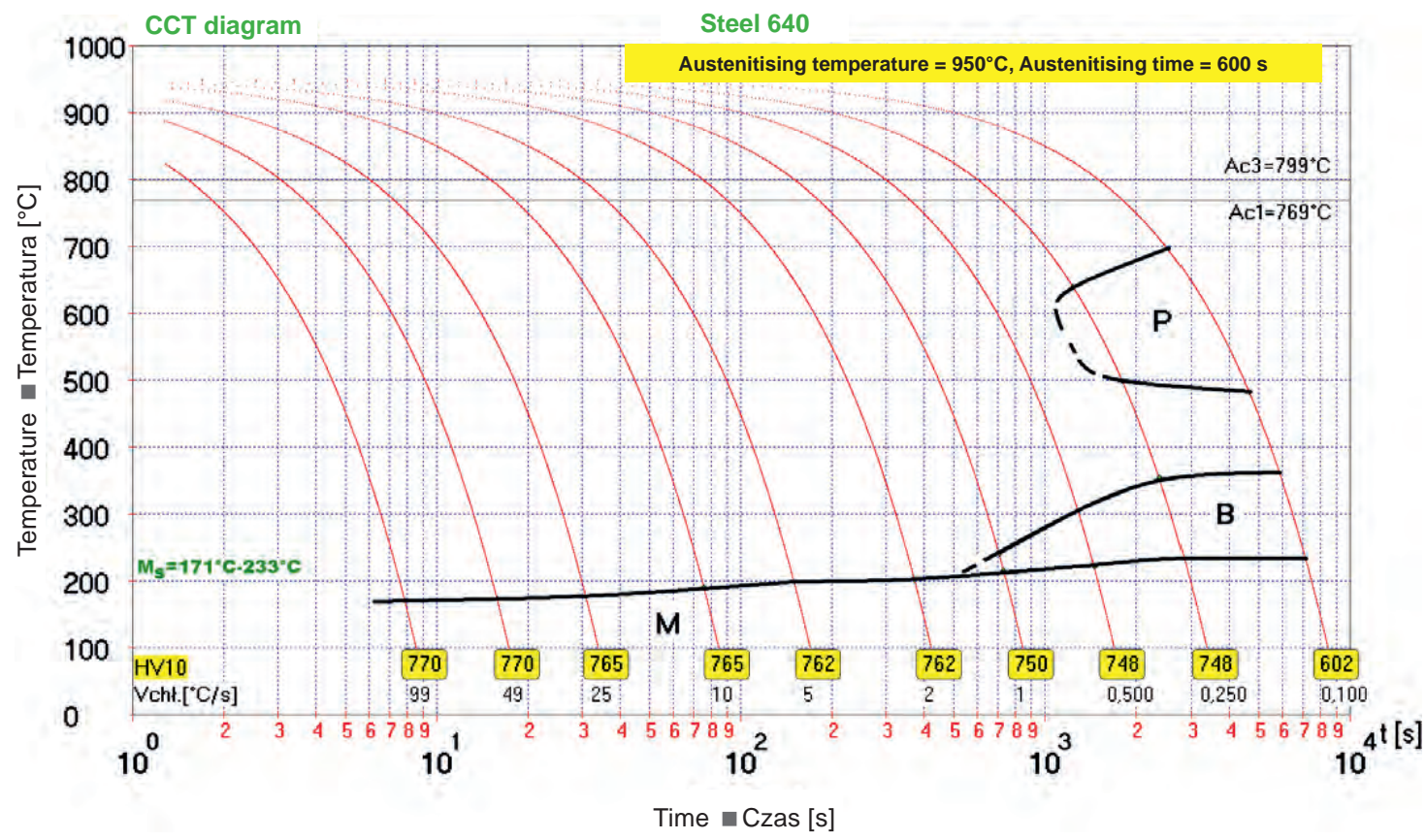

Fig. 3. CCT diagram for nanostructured bainitic steel - heat 640

Rys. 3. Diagram CTPc stali nanostrukturalnej bainitycznej - wytop 640 
ment of plates was maintained. $M_{\mathrm{s}}$ temperature changes for a wide range of cooling rate are marked in Fig. 3. The kinetic curves indicate that, for the time range used, the transformation takes place to a large extent at $210-240^{\circ} \mathrm{C}$. After isothermal annealing, the samples were subjected to microstructure tests and hardness measurement. As a result of isothermal annealing at temperatures of $210-240^{\circ} \mathrm{C}$, a typical microstructure of carbide-free nanolath bainite and retained austenite were obtained, similar to the results of [10-14]. Based on the results of dilatometric tests, experiments of heat treatment of tensile and impact samples were carried out. The samples were heated to $950^{\circ} \mathrm{C}$ and annealed for 30 minutes and cooled in air to the temperature of isothermal transformation. Then, direct isothermal annealing was applied in the temperature range of $200-240^{\circ} \mathrm{C}$ for 72 to 137 hours.

Hardness measurement and microstructure results of investigation were performed on the non-deformed parts of the samples. Fig. 4 presents typical images of the tested samples' microstructure. Depending on the temperature of isothermal transformation, the steel microstructure consists of lath packets of carbide-free bainite and retained austenite, and in the case of transformation temperature below $M_{\mathrm{s}}$, additional lathy martensite is formed, which is tempered. The value of the isothermal annealing temperature affects the width of bainite laths and the content and form of retained austenite, in such a way that the higher the transformation temperature, the greater the width of the laths and the greater the content of retained austenite. The principle mentioned above, due to the heterogeneity of the material, typical for the production conditions related to the casting method, and slight differences in the applied temperatures of isothermal annealing, is not always met. The results of measurement of the austenite content for laboratory heats and selected variants of heat treatment are presented in Table 4 . The preliminary correlation analysis of the austenite content and the mechanical and functional properties of the material indicates that the optimal volume fraction of retained austenite should not exceed
$20 \%$, and most preferably be within the range of $13-18 \%$. The results of the measurement of mechanical properties in a static tensile test are presented in Table 5. Taking into account the values of mechanical properties, the shape of the tensile curves in terms of strengthening and the value of the TS/YS ratio, variants were selected for the production of plates for firing tests. Mechanical properties assumed in the project: TS min. $2000 \mathrm{MPa}$, TE $\min .12 \%$ and impact strength $K V \min .12 \mathrm{~J}$ at ambient temperature were met for the developed chemical compositions of steel and most of the applied heat treatment variants.

Table 4. Results of retained austenite content measurement. Laboratory heat 640/XRD method

Tabela 4. Wyniki pomiarów zawartości austenitu resztkowego. Wytop laboratoryjny 640/Metoda XRD

\begin{tabular}{|c|c|}
\hline $\begin{array}{c}\text { Sample identification } \\
\text { (heat treatment variant }- \\
\text { temp., }{ }^{\circ} \mathbf{C} \text { ]/time, [h]) }\end{array}$ & $\begin{array}{c}\text { Retained austenite } \\
\text { volume fraction, } \\
\text { [\%] }\end{array}$ \\
\hline $210 / 116$ & 13.0 \\
\hline \multirow{2}{*}{$210 / 120$} & 15.2 \\
\hline \multirow{2}{*}{$215 / 96$} & 13.9 \\
\hline \multirow{2}{*}{$220 / 72$} & 10.4 \\
\hline \multirow{2}{*}{$220 / 94$} & 21.0 \\
\hline \multirow{2}{*}{$220 / 96$} & 17.5 \\
\hline \multirow{2}{*}{$225 / 70$} & 13.7 \\
\hline \multirow{2}{*}{$235 / 72$} & 13.8 \\
\hline \multirow{2}{*}{$235 / 100$} & 12.1 \\
\hline & 15.3 \\
\hline & 17.8 \\
\hline & 16.9 \\
\hline
\end{tabular}
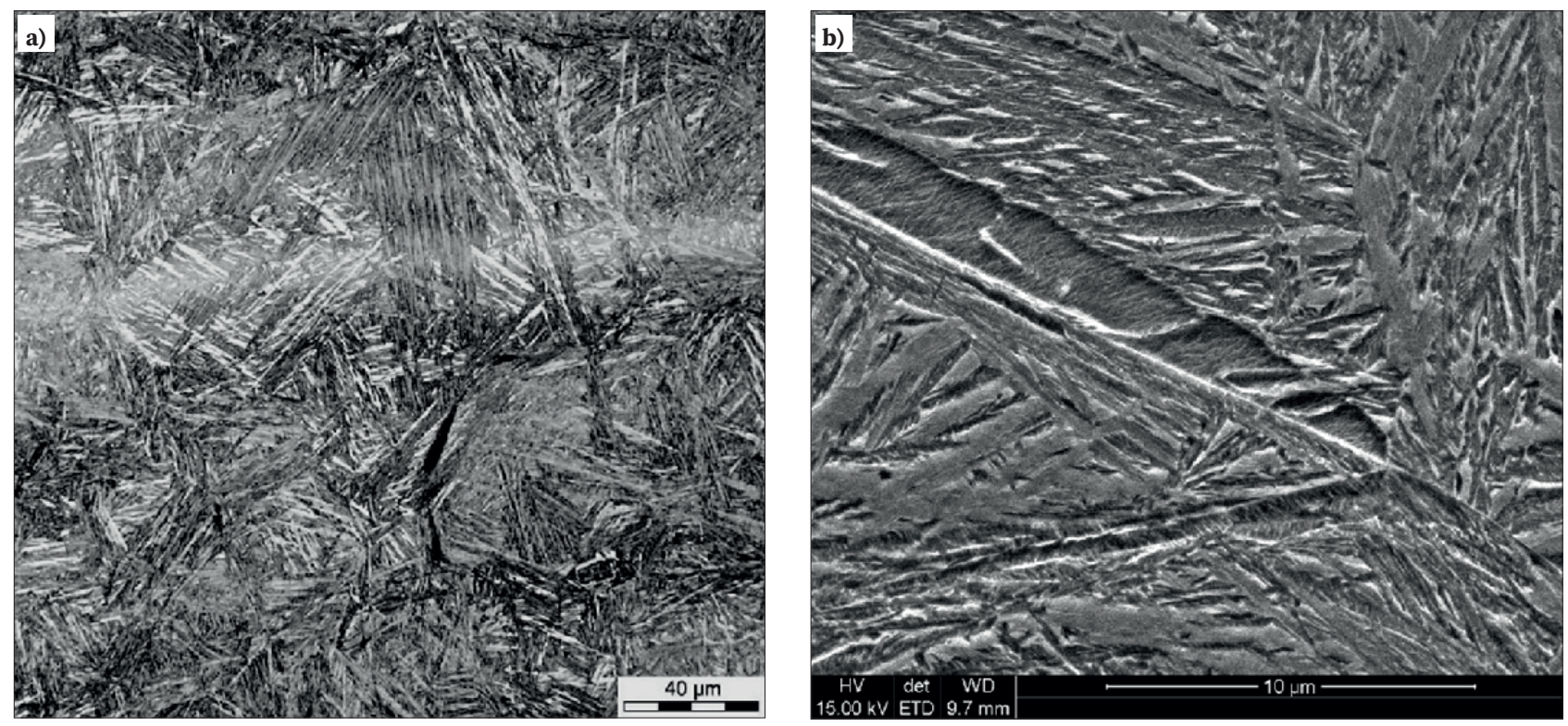

Fig. 4. Microstructure of NBA steel-heat 640 after isothermal treatment: a) light microscope, b) scanning electron microscope (220/96) Rys. 4. Mikrostruktura stali NBA-wytop 640 po obróbce izotermicznej: a) mikroskop świetlny, b) skaningowy mikroskop elektronowy (220/96) 
Table 5. Results of measurement of mechanical properties in static tensile test. Laboratory heats Tabela 5. Wyniki pomiarów właściwości mechanicznych w statycznej próbie rozciagania. Wytopy laboratoryjne

\begin{tabular}{|c|c|c|c|c|c|}
\hline $\begin{array}{l}\text { Heat No. - identification of isothermal annealing } \\
\left.\text { variant (temp., }\left[{ }^{\circ} \mathrm{C}\right] / \text { time, }[\mathrm{h}]\right)\end{array}$ & $\begin{array}{c}Y S \\
{[\mathrm{MPa}]}\end{array}$ & $\begin{array}{c}\text { TS } \\
{[\mathrm{MPa}]}\end{array}$ & $\begin{array}{c}T E \\
{[\%]}\end{array}$ & $\begin{array}{l}U E^{*} \\
{[\%]}\end{array}$ & TS/YS \\
\hline \multirow{2}{*}{$617-210 / 137$} & 1366 & 2165 & 13.1 & 11.2 & 1.58 \\
\hline & 1279 & 2064 & 8.7 & 4.4 & 1.61 \\
\hline \multirow{2}{*}{$617-230 / 96$} & 1354 & 2022 & 12.4 & 10.2 & 1.49 \\
\hline & 1330 & 2008 & 14.4 & 10.4 & 1.51 \\
\hline \multirow{2}{*}{$640-210 / 116$} & 1470 & 2072 & 11.5 & 8.7 & 1.41 \\
\hline & 1467 & 2097 & 12.5 & 9.0 & 1.43 \\
\hline \multirow{2}{*}{$640-210 / 120$} & 1497 & 2109 & 8.0 & 7.7 & 1.41 \\
\hline & 1451 & 2107 & 12.2 & 8.3 & 1.45 \\
\hline \multirow{2}{*}{$640-215 / 96$} & 1455 & 2068 & 11.7 & 8.3 & 1.42 \\
\hline & 1457 & 2091 & 12.5 & 8.6 & 1.44 \\
\hline $640-220 / 72$ & 1436 & 2132 & 11.6 & 8.2 & 1.48 \\
\hline \multirow{2}{*}{$640-220 / 94$} & 1516 & 2095 & 10.4 & 9.1 & 1.38 \\
\hline & 1533 & 2112 & 10.7 & 8.6 & 1.38 \\
\hline \multirow{2}{*}{$640-220 / 96$} & 1485 & 2081 & 13.1 & 8.0 & 1.40 \\
\hline & 1535 & 2106 & 12.2 & 8.1 & 1.37 \\
\hline \multirow{2}{*}{$641-210 / 116$} & 1154 & 2087 & 14.0 & 11.4 & 1.81 \\
\hline & 1242 & 2059 & 14.0 & 10.8 & 1.66 \\
\hline \multirow{2}{*}{$641-210 / 120$} & 1164 & 2102 & 14.0 & 11.9 & 1.81 \\
\hline & 1168 & 2096 & 12.7 & 11.5 & 1.79 \\
\hline \multirow{2}{*}{$648-215 / 96$} & 1244 & 2000 & 14.4 & 11.1 & 1.61 \\
\hline & 1265 & 1996 & 10.7 & 10.2 & 1.58 \\
\hline
\end{tabular}

*UE - uniform elongation

\subsection{FIRING TEST RESULTS}

Firing tests of material from laboratory heats were carried out with the use of $7.62 \times 51 \mathrm{~mm}$ API BZ ammunition and, additionally, $5.56 \times 45 \mathrm{~mm}$ M193 ammunition. Two plate sections (flat bars) from laboratory heats 617, 640, 641 and 648 were prepared for the firing tests. Firing tests were carried out at an angle of $0^{\circ}$ for the actual thickness in the range of 7.0-8.5 $\mathrm{mm}$ and at an angle of $30^{\circ}$ for plate thickness in the range of $5.3-6.3 \mathrm{~mm}$. Based on the observation immediately after the firing, no cracks were found on the plate as a result of multi-hit firing. Typical test results and photographs of plates after the firing are presented in Table 6 and Fig. 5, respectively.

Table 6. Firing test results for laboratory heat plates

Tabela 6. Przykładowe wyniki testów ostrzałem blach z wytopów laboratoryjnych

\begin{tabular}{|c|c|c|c|c|}
\hline $\begin{array}{l}\text { No. } \\
\text { (test No. - Fig. } 5)\end{array}$ & $\begin{array}{l}\text { Heat / HT parameters } \\
\left.\text { (temp., }\left[{ }^{\circ} \mathrm{C}\right] \text {, time, }[\mathrm{h}]\right)\end{array}$ & $\begin{array}{l}\text { Ammunition type, } \\
\text { firing angle, plate thickness }\end{array}$ & $\begin{array}{l}\text { Impact velocity, } \\
{[\mathrm{m} / \mathrm{s}]}\end{array}$ & $\begin{array}{c}\text { Test result } \\
\text { NP - no perforation, } \mathrm{P}-\text { perforation }\end{array}$ \\
\hline 1 & \multirow{3}{*}{$640(215 / 96)$} & \multirow{3}{*}{$\begin{array}{l}7.62 \times 39 \mathrm{~mm} \text { API BZ } \\
\left(0^{\circ}\right) \# 7.5 \mathrm{~mm}\end{array}$} & 718.2 & NP \\
\hline 2 & & & 713.1 & $\mathrm{P}$ \\
\hline 3 & & & 714.1 & NP \\
\hline 4 & \multirow{3}{*}{$640(215 / 96)$} & \multirow{3}{*}{$\begin{array}{l}5.56 \times 45 \mathrm{~mm} \mathrm{M} 193 \\
\left(0^{\circ}\right) \# 7.5 \mathrm{~mm}\end{array}$} & 943.6 & NP \\
\hline 5 & & & 940.2 & NP \\
\hline 6 & & & 949.2 & NP \\
\hline 1 & \multirow{4}{*}{$640(220 / 71)$} & \multirow{4}{*}{$\begin{array}{l}5.56 \times 45 \mathrm{~mm} \mathrm{M} 193 \\
\left(30^{\circ}\right) \# 6.3 \mathrm{~mm}\end{array}$} & 934.8 & NP \\
\hline 2 & & & 946.2 & NP \\
\hline 3 & & & 939.2 & NP \\
\hline 4 & & & 931.7 & NP \\
\hline 5 & \multirow{4}{*}{$640(220 / 71)$} & \multirow{4}{*}{$\begin{array}{l}7.62 \times 39 \mathrm{~mm} \text { API BZ } \\
\left(30^{\circ}\right) \# 6.3 \mathrm{~mm}\end{array}$} & 707.7 & NP \\
\hline 6 & & & 706.1 & NP \\
\hline 7 & & & 710.8 & NP \\
\hline 8 & & & 703.4 & NP \\
\hline
\end{tabular}



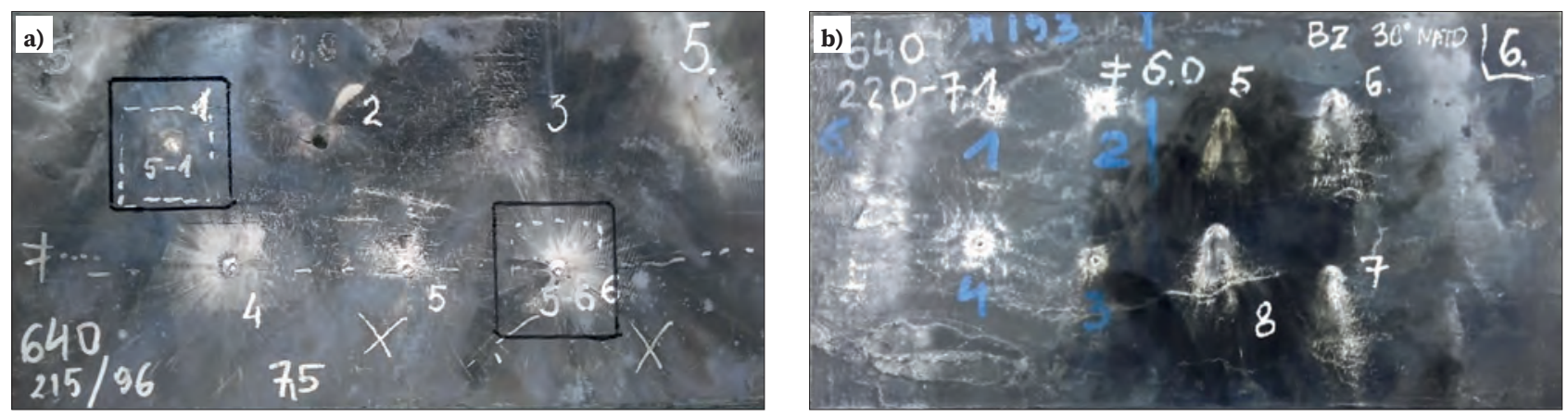

Fig. 5. Photographs of nanostructured bainitic steel plates after firing. Laboratory heat 640

Rys. 5. Fotografie blach ze stali bainitycznych nanostrukturalnych po ostrzale. Wytop laboratoryjny 640
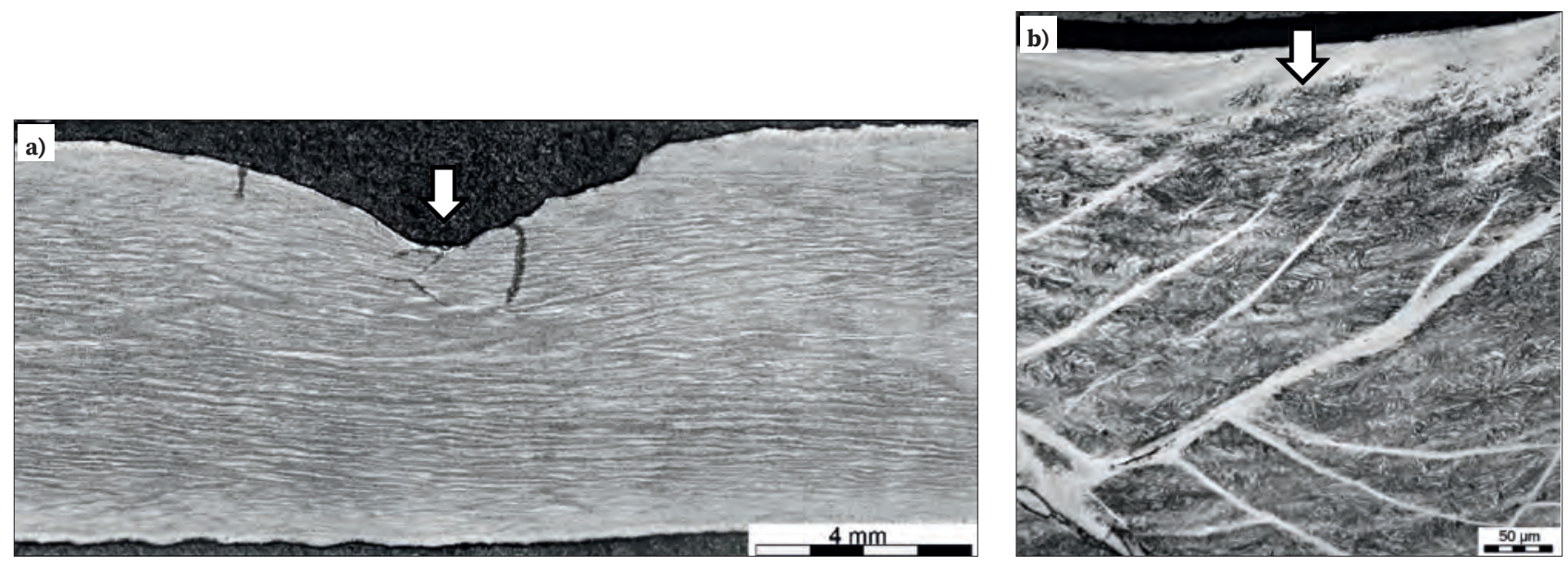

Fig. 6. Sample results of : a) macro- and b) microstructure tests in the area of the projectile core-plate interaction, heat 640, marked direction of the projectile's trajectory

Rys. 6. Przykładowe wyniki badań: a) makro- i b) mikrostruktury w obszarze oddziaływania rdzenia pocisku z blachą, wytop 640, zaznaczono kierunek lotu pocisku

For selected variants of heat treatment and test parameters, microstructure tests were performed at projectile impact sites. The purpose of the tests included the assessment of the degree of degradation and depth of penetration. Based on the test results, a comparative analysis of the materials was carried out in terms of resistance to perforation, including in terms of the occurrence of shear bands, macro- and microcracks and the bullet core penetration depth or the degree of knocking out of the "plug" (also the tendency to the formation of secondary shrapnel). Two typical penetration mechanisms were observed: adiabatic shear for the M193 projectile and erosion for the incendiary AP projectile (Fig. 6). The assessment of the degree of degradation of the firing locations was used in the final stage of selecting the chemical composition and parameters of material production on an industrial scale. The results of the research indicated, among others, the influence of the segregation of elements formed during solidification - and, consequently, the banding of the microstructure - on the resistance to perforation of the plates.

\section{TEST RESULTS OF MATERIAL PRODUCED IN INDUSTRIAL CONDITIONS}

\subsection{PRELIMINARY RESULTS OF THE STUDY OF MICROSTRUCTURE AND MECHANICAL PROPERTIES}

The preliminary tests were carried out on a $6 \mathrm{~mm}$ thick plate section from heat P1 after hot rolling. The scope of the tests included microstructure characteristics and hardness measurement. Subsequently, heat treatment of softening annealing and austenitising, as well as a final treatment including austenitising and direct isothermal annealing were performed. The microstructure of the plates after rolling and slow cooling in a stack was composed of martensite, bainite and pearlite (Fig. 7a). There was a microstructure banding typical of hot-rolled plates, with bands distributed evenly on the thickness (Fig. 7b). The results of the plate's surface quality examination showed that the thickness of the oxidised layer was approx. $20 \mu \mathrm{m}$. Despite cooling, the stacked material reached the hardness of approx. $60 \mathrm{HRC}$. Heat treatment was carried out to soften the steel. A temperature of $690^{\circ} \mathrm{C}$ and cooling with the furnace were applied. The microstructure of the steel after this heat treatment, causing recrystallisation of the matrix and the precipitation and growth of carbides, was made of ferrite and partially coagulated carbides with a diameter below approx. $200 \mathrm{~nm}$ (Fig. 7c). As a result of the softening, the hardness of the material was reduced to $33 \mathrm{HRC}(318 \mathrm{HV})$. In the next stage of the study, the austenitising process was analysed, as a result of which a homogeneous austenite with the smallest grain size should be obtained (without carbides that should dissolve). For this purpose, heat treatment was carried out with two temperatures of 930 and $955^{\circ} \mathrm{C}$ and a holding time of 30 minutes. After heat treatment, microstructure results of investigation were performed in order to verify the correctness of the parameters used, based on the presence of primary precipitates and grain size. After austenitising at $930^{\circ} \mathrm{C}$, the presence of single $\mathrm{Cr}$ and Mo carbides was observed. After austenitising at 
$955^{\circ} \mathrm{C}$, carbides smaller than $200 \mathrm{~nm}$ were sporadic. Based on the research, the austenitising temperature in the final heat treatment process was determined to be $950^{\circ} \mathrm{C}$ and the holding time at this temperature was 30 minutes. In the last stage of the preliminary tests, the final heat treatment was carried out, consisting in isothermal annealing immediately after austenitisation and controlled cooling. Based on the tests carried out on the material produced in laboratory conditions, an isothermal annealing temperature of $215^{\circ} \mathrm{C}$ and a time of 96 hours were used. The transverse tensile samples (perpendicular to the rolling direction of the plates), which were the material for the study of microstructure and mechanical properties, were processed. A typical tensile curve is presented in Fig. 7d. The assumed properties were obtained: tensile strength higher than $2000 \mathrm{MPa}$ and elongation above 12\%, with a yield strength of approx. $1500 \mathrm{MPa}$. During quasi-static tensile tests, the samples exhibited a distinct narrowing and the ductile nature of the fracture surface. In the areas of the holders of strength samples, microstructure studies were performed using a scanning electron microscope, which were nanobainite packets without the presence of carbides.

\subsection{RESULTS OF DILATOMETRIC TESTS}

Figs. 8 and 9 present CCT phase transformation diagrams for industrial test heats. The following temperatures characteristic for heating were determined based on the analysis of dilation curves. P1: $A c_{1}=747^{\circ} \mathrm{C} ; A c_{3}=847^{\circ} \mathrm{C}$; P2: $A c_{1}=750^{\circ} \mathrm{C} ; A c_{3}=848^{\circ} \mathrm{C}$. The austenitising temperature used before isothermal annealing for samples from both test heats was $950^{\circ} \mathrm{C}$. The experiments and studies of the austenitising process carried out so far have confirmed that annealing at the temperature of $950^{\circ} \mathrm{C}$ for $30-60 \mathrm{~min}-$ utes guarantees obtaining a homogeneous austenite solution without the presence of carbides and does not lead to excessive growth of austenite grains. $M_{\mathrm{s}}$ temperatures for industrial heats were determined after austenitising at $950^{\circ} \mathrm{C}$ for $600 \mathrm{~s}$ and with cooling with a rate of $1-100^{\circ} \mathrm{C} / \mathrm{s}$. The cooling rate applied in practice is within the following range: $1-5^{\circ} \mathrm{C} / \mathrm{s}$. For this range of cooling rate, the $M_{\mathrm{s}}$ temperature ranges from 201 to $220^{\circ} \mathrm{C}$ for heat $\mathrm{P} 1$ and from 197 to $205^{\circ} \mathrm{C}$ for heat $\mathrm{P} 2$.
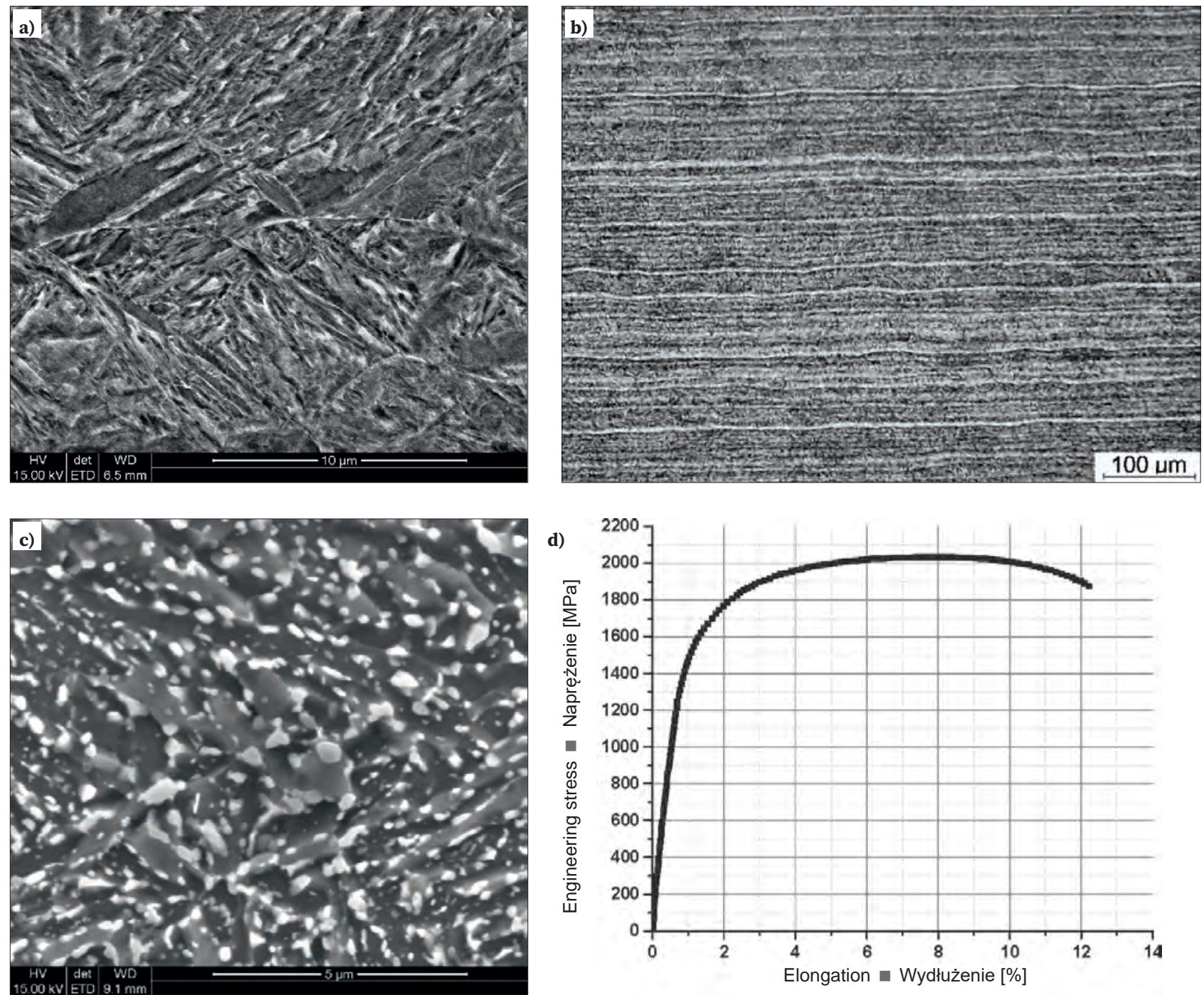

Fig. 7. Microstructure of nanostructured bainitic steel after rolling $(\mathrm{a}, \mathrm{b})$ after softening annealing at $690^{\circ} \mathrm{C}$ for $6 \mathrm{hours}(\mathrm{c})$ and tensile curve of nanobainite steel for the $215^{\circ} \mathrm{C} / 96$ hours variant. Heat P1, transverse samples (perpendicular to the rolling direction) (d)

Rys. 7. Mikrostruktura stali bainitycznej nanostrukturalnej po walcowaniu (a, b) po wyżarzaniu zmiękczającym w temperaturze $690^{\circ} \mathrm{C}$ przez 6 godzin (c) oraz krzywa rozciagania stali nanobainitycznej dla wariantu $215^{\circ} \mathrm{C} / 96$ godzin. Wytop P1, próbki poprzeczne (prostopadłe do kierunku walcowania) (d) 


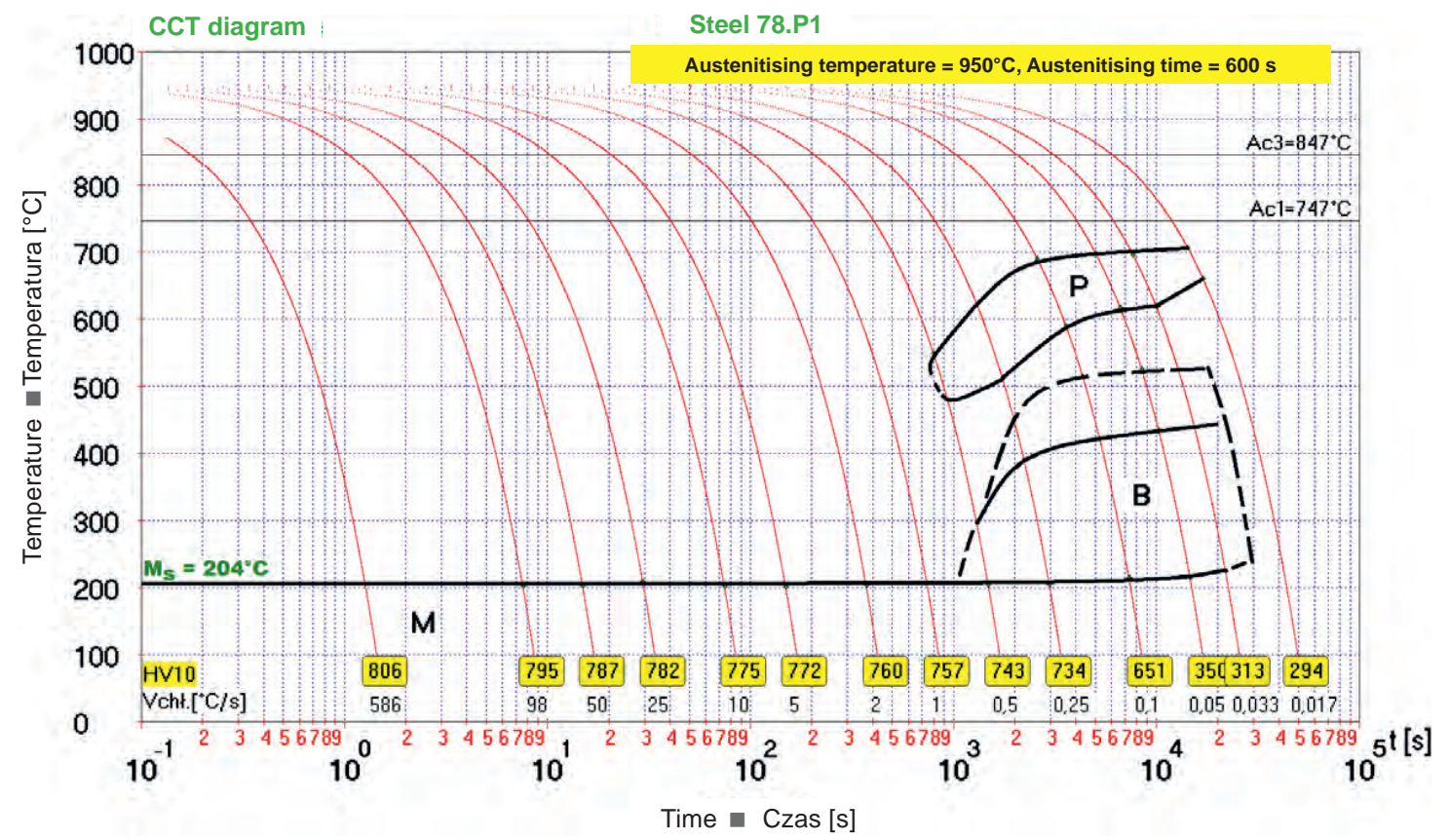

Fig. 8. CCT diagram for nanobainitic steel. Heat P1

Rys. 8. Diagram CTPc stali nanobainitycznej. Wytop P1

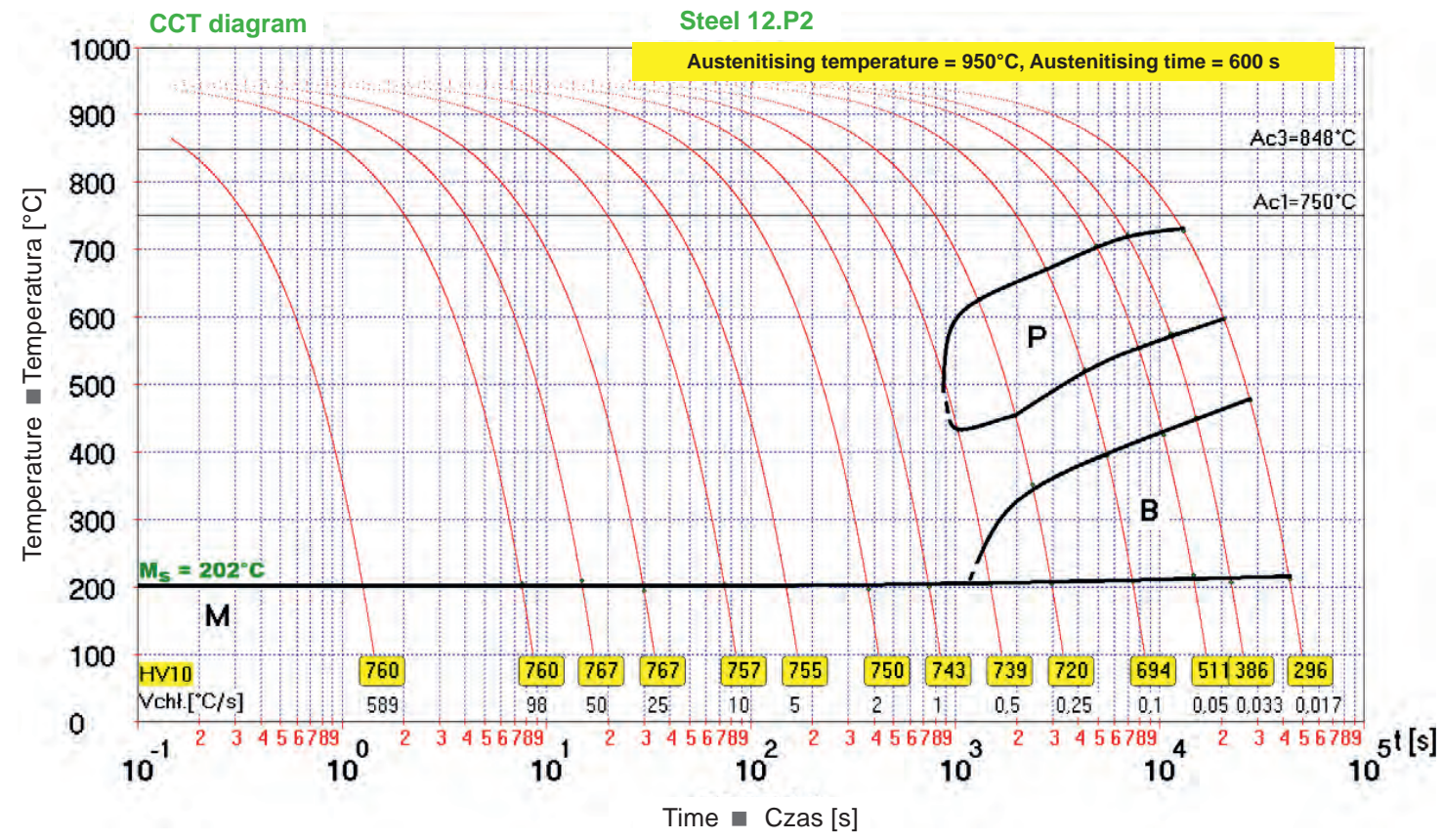

Fig. 9. CCT diagram for nanobainitic steel. Heat P2

Rys. 9. Diagram CTPc stali nanobainitycznej. Wytop P2

\subsection{TEST RESULTS AFTER FINAL HEAT TREATMENT IN LABORATORY FURNACES}

Before the guidelines for the technology of heat treatment of plates were developed, a wide range of tests and analyses of industrial material was carried out, which was subjected to heat treatment at Łukasiewicz - IMŻ. Characteristics in terms of microstructure and mechanical properties were developed for this material, and its protective effectiveness was assessed in firing tests. The test results were the basis for indicating the conditions for industrial heat treatment, which is a key stage of technology, shaping the functional properties.

\subsubsection{Results of microstructure examination}

Fig. 10 presents microstructure images of nanobainitic steel after final heat treatment. The range of magnifications used in the light microscope enables the observation of the following features characterising the material: banding, surface oxidation and decarburisation, non-metallic inclusions larger than approx. $1 \mu \mathrm{m}$, microstructure components up to a specific level of detail. In the case of nanobainitic steel plates, there is microstructural banding, and the distance between adjacent bands is from 10 to $20 \mu \mathrm{m}$. The microstructure of the material after the final heat treatment consists of packets of nanobainite laths. At high- 

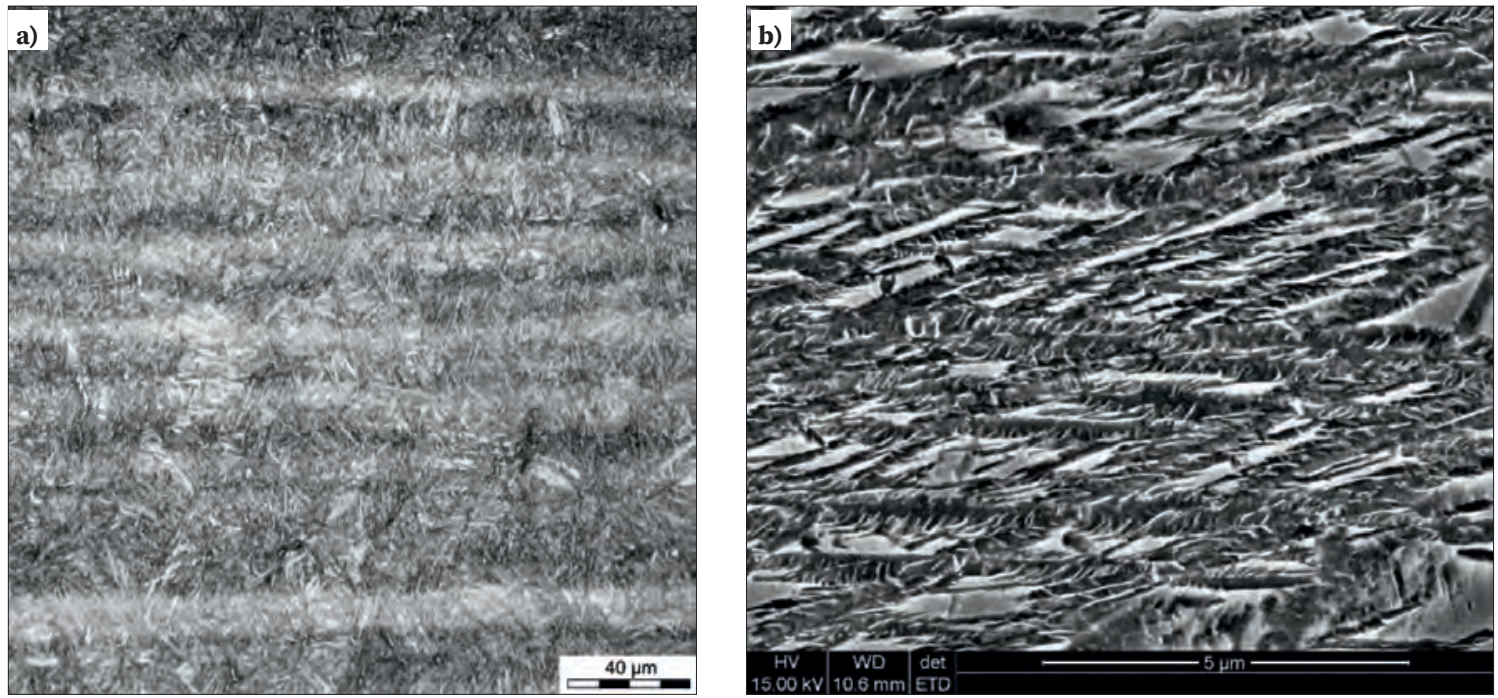

Fig. 10. Microstructure on longitudinal microsection of $P 2$ heat plate - variant 215/96. Light microscope (a), scanning electron microscope (b) Rys. 10. Mikrostruktura na przekroju wzdłużnym blachy z wytopu P2-wariant 215/96. Mikroskop świetlny (a), skaningowy mikroskop elektronowy (b)

er magnifications, in particular in the areas of segregation with a higher content of elements than the average composition (in light bands), individual grains of blocky retained austenite can be observed (Fig. 10a). A detailed analysis of the retained austenite morphology can be assessed using a scanning microscope (blocky austenite $-\mathrm{A}_{\mathrm{B}}$ ) and a transmission electron microscope (lathy austenite $-A_{L}$ ). Fig. 10b presents the results of investigation of the microstructure of nanobainitic steel from the P2 heat - variant 215/96 using SEM. The microstructure consists of laths of nanobainite. Slight differences in nanobainite morphology were observed in the segregation (banded) areas. A typical microstructure consisting of nanobainite laths was present in areas depleted in alloying elements (Mo, Cr, Mn, Si). In areas enriched with the above-mentioned alloying elements, a higher content of components in the form of blocks, including retained austenite, was observed. A clear identification of blocky retained austenite using observation with the applied magnifications and the method of revealing (etching) the microstructure is not possible. Therefore, detailed morphology studies and measurement of the volume fraction of blocky retained austenite were performed using the EBSD method.
The study of the microstructure of nanobainitic steel with the use of a transmission electron microscope allows the identification of the following microstructure components: carbide-free bainite nanolaths, retained nanolathy austenite located between bainite laths, blocky retained austenite and precipitates - if thermodynamic conditions for their formation occurred in the manufacturing process.

TEM microstructure examination results are presented in Fig. 11. The observed type of lathy and blocky retained austenite morphology using the electron diffraction method and the dark field of view technique confirmed the presence of two austenite fractions in nanobainitic steel after the final heat treatment. No carbide precipitates were observed in the study.

\subsubsection{Results of retained austenite examination}

The results of retained austenite volume fraction measurement are presented in Table 7. Table 7 also presents the results of measurement of the volume fraction of blocky retained austenite determined using the EBSD method for the $5000 \times$ and $8000 \times$ magnifications. At a magnification of $8000 \times$, the minimum size of the area (austenite phase) that can be analysed is between 100 and $200 \mathrm{~nm}$. For the
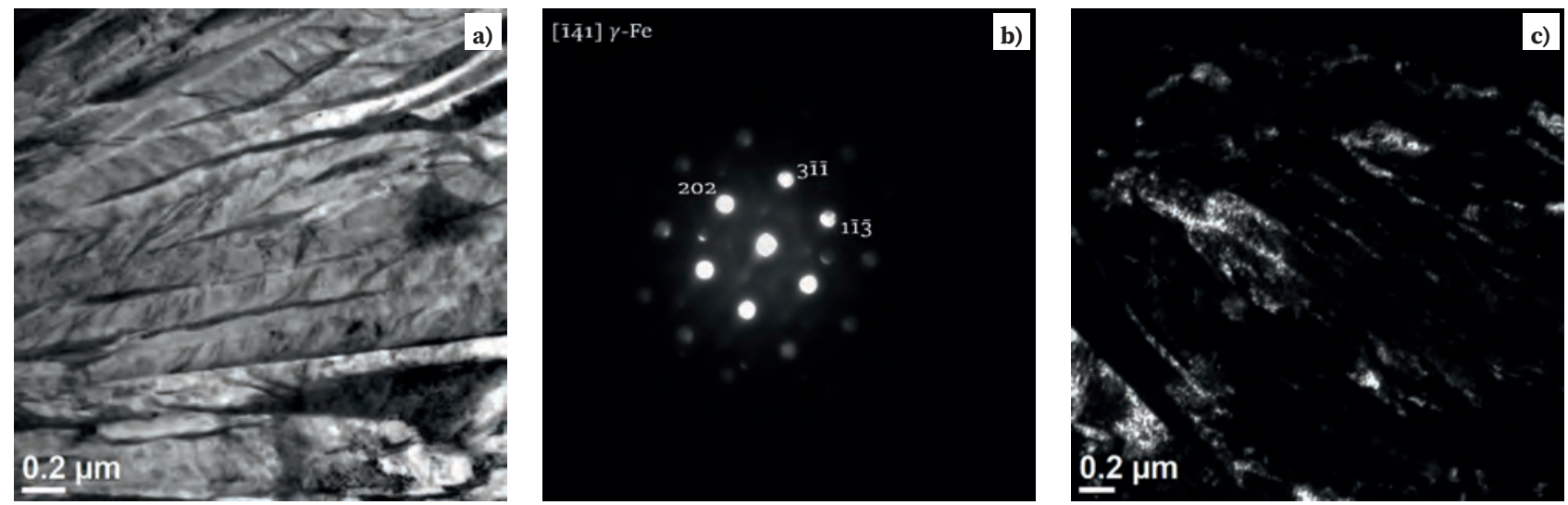

Fig. 11. Microstructure of nanobainitic steel, heat P1, variant 215/96; a) aright field image, b) blectron diffraction pattern, c) dark field image in the reflex of retained lath austenite

Rys. 11. Mikrostruktura stali nanobainitycznej, wytop P1, wariant 215/96; a) jasne pole widzenia, b) dyfrakcja elektronowa, c) ciemne pole widzenia $\mathrm{w}$ refleksie austenitu resztkowego listwowego 
Table 7. Results of retained austenite content measurement using the XRD and EBSD method

Tabela 7. Wyniki pomiarów zawartości austenitu resztkowego metodami XRD i EBSD

\begin{tabular}{|c|c|c|c|}
\hline \multirow{2}{*}{$\begin{array}{c}\text { Sample } \\
\text { identification }\end{array}$} & \multirow{2}{*}{$\begin{array}{c}\begin{array}{c}\text { Total retained } \\
\text { austenite volume } \\
\text { fraction, [vol\%] }\end{array} \\
\mathbf{g}_{\text {XRD }}\end{array}$} & \multicolumn{2}{|c|}{$\begin{array}{l}\text { Retained austenite volume } \\
\text { fraction, [vol\%] }\end{array}$} \\
\hline & & $\begin{array}{c}\gamma_{\text {EBSD }} \\
\text { magn. } 5000 \times\end{array}$ & $\begin{array}{c}\gamma_{\text {EBSD }} \\
\text { magn. 8000× }\end{array}$ \\
\hline P1.210/96 & $14.5 \pm 1.6$ & $11.1 ; 9.5$ & $11.7 ; 11.4$ \\
\hline $\mathrm{P} 1.210 / 120$ & $14.9 \pm 0.9$ & $8.3 ; 10.5$ & $8.3 ; 11.4$ \\
\hline $\mathrm{P} 1.215 / 96$ & $14.8 \pm 2.2$ & $9.6 ; 13.0$ & $8.5 ; 15.1$ \\
\hline $\mathrm{P} 1.225 / 72$ & $17.5 \pm 1.9$ & $11.2 ; 12.3$ & $12.1 ; 12.4$ \\
\hline $\mathrm{P} 2.210 / 48$ & $22.5 \pm 2.7$ & $7.8 ; 8.4$ & $6.8 ; 8.6$ \\
\hline $\mathrm{P} 2.210 / 72$ & $20.6 \pm 2.7$ & $6.5 ; 5.5$ & $6.7 ; 8.7$ \\
\hline P2.210/96 & $15.5 \pm 1.5$ & $10.9 ; 9.5$ & $12.4 ; 9.5$ \\
\hline P2.210/120 & $22.6 \pm 1.2$ & $11.9 ; 9.9$ & $13.4 ; 9.3$ \\
\hline $\mathrm{P} 2.215 / 96$ & $25.0 \pm 1.2$ & $10.4 ; 9.2$ & $10.4 ; 8.2$ \\
\hline $\mathrm{P} 2.225 / 72$ & $15.6 \pm 0.4$ & $7.3 ; 6.4$ & $9.2 ; 8.9$ \\
\hline
\end{tabular}

tested heat treatment variants from heat $\mathrm{P} 1$, the content of austenite was $15-17 \%$. In the case of the P2 heat, the austenite content for the same heat treatment parameters as for $\mathrm{P} 1$ ranged from 20 to $25 \%$. Similar contents of retained austenite were obtained by the authors of [8], which seems to be typical for nanobainitic steels and the isothermal transformation temperatures used. The volume fraction of retained austenite determined using the X-ray method is higher than the values determined using the EBSD method. This is confirmed by the presence of a nanolathy austenite fraction, which is not identifiable using the EBSD method.

The investigation of the morphology and volume fraction of blocky retained austenite was performed in SEM using the EBSD method at three magnifications of $3000 \times, 5000 \times$ and $8000 \times$. The smallest of the magnifications allowed for the analysis of the uniformity of blocky austenite distribution - e.g. in the areas of banded microstructure, but the minimum identifiable grain size of the austenite phase was limited to approx. $1 \mu \mathrm{m}$. Therefore, the content of retained austenite determined at the magnification of $3000 \times$ does not take into account the entire blocky austenite fraction. Blocky austenite grains/laths with sizes ranging from $100-200 \mathrm{~nm}(0.1-0.2 \mu \mathrm{m})$ were observed at 5000× and 8000× magnification. The measurement results of the fraction of blocky retained austenite volume at a magnification of $5000 \times$ were used for further analyses, e.g. to determine the content of nanolathy austenite.

Fig. 12 presents exemplary test results for blocky retained austenite in the $\mathrm{P} 2$ heat material after the final heat treatment. Studies at $3000 \times$ magnification showed the occurrence of inhomogeneity in the distribution of retained austenite with a grain size greater than $1 \mu \mathrm{m}$. This austenite fraction was characterised by a morphology close to equiaxed (globular) (Fig. 12 a,b). The distances between the zones with an increased content of blocky austenite $(10-20 \mu \mathrm{m})$, the location of these zones and their width correspond to the banding of the microstructure of the plates found using the light microscopy examination. At the magnification of $5000 \times$ and $8000 \times$, two types of retained austenite morphology were observed: globular grains and laths. The width of the laths and the mean linear intercept were in the range of $0.1-1.0 \mu \mathrm{m}$, and the maximum length of the laths reached approx. $3 \mu \mathrm{m}$ (Fig. 12c-e).

\subsubsection{Results of measurement of mechanical properties in static tensile test}

The measurement of mechanical properties was taken on flat samples taken from hot-rolled plates, which were finally heat treated in heating furnaces at Łukasiewicz -
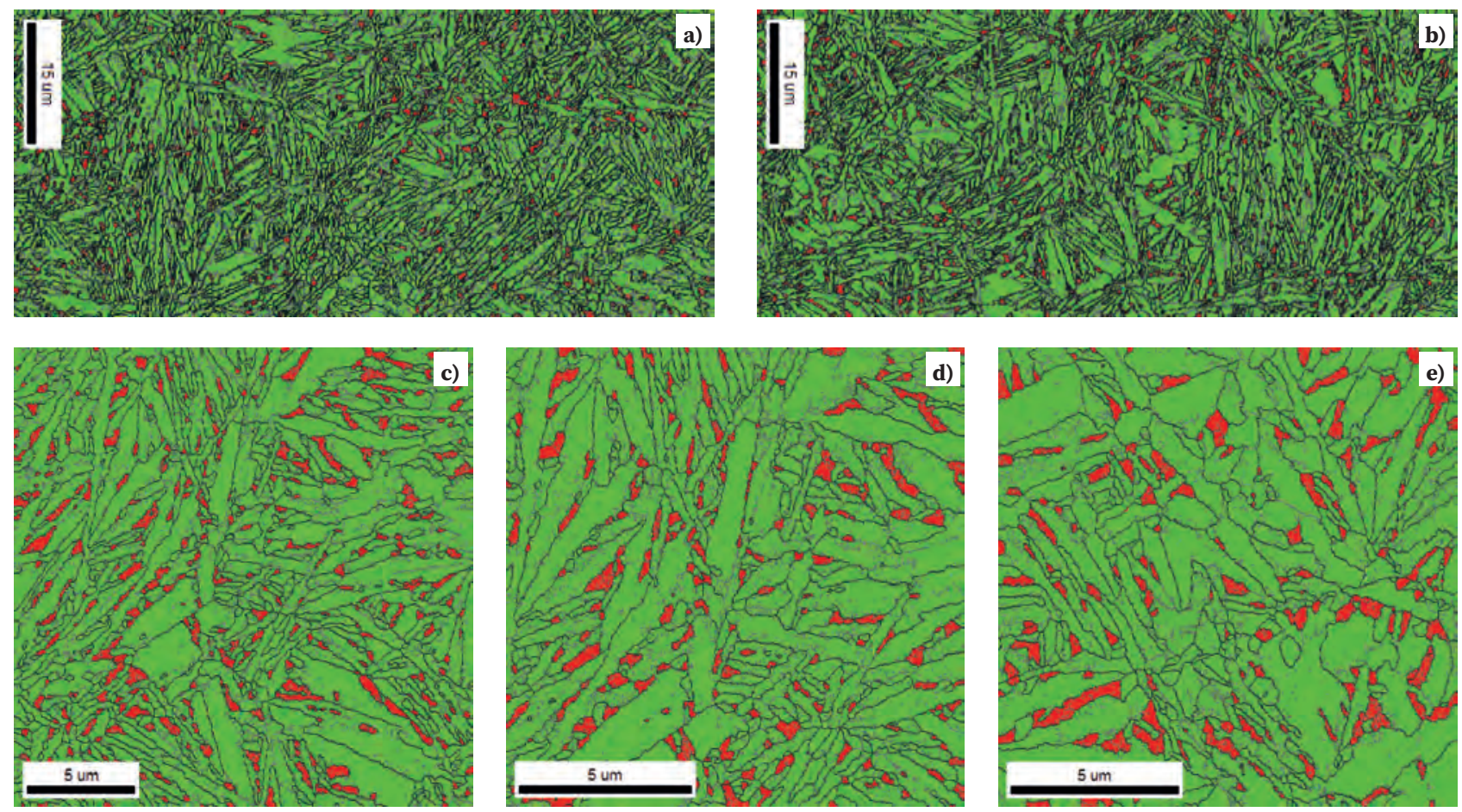

Fig. 12. Results of volume fraction measurement and blocky retained austenite morphology investigation. Heat P2, variant $210 / 96$ (a, c, d) and variant 215/96 (b, e). a,b) magn. 3000×; c) magn. 5000×; d,e) magn. 8000×. Scanning electron microscope, EBSD method

Rys. 12. Wyniki pomiarów ułamka objętości oraz badań morfologii austenitu resztkowego blokowego. Wytop P2, wariant 210/96 (a, c, d) i wariant 215/96 (b, e). a,b) pow. 3000×; c) pow. 5000×; d,e) 8000×. Skaningowy mikroskop elektronowy, metoda EBSD 
IMŻ. The results of the measurement of the mechanical properties are presented in Tables 8 and 9, respectively, for the P1 and P2 heats, and in Table 10, the results of the impact strength measurement. In accordance with the assumptions of the project, the tensile strength was obtained for several variants of heat treatment and for both heats, with a total elongation greater than $12 \%$. Nanobainitic steel is characterised by a wide range of deformation strengthening after exceeding the yield strength (YS) of 1300 to $1500 \mathrm{MPa}$ for the following ranges of isothermal annealing parameters: temperature $T=210,215,225^{\circ} \mathrm{C}$; time $t=120,96,72$ hours, respectively. The obtained results of the measurement of properties in the static tensile test are similar to the results of [3-10] in terms of strength, howev-

Table 8. Results of the measurement of mechanical properties in a static tensile test, nanobainitic steel, heat $P 1$

Tabela 8. Wyniki pomiarów właściwości mechanicznych w statycznej próbie rozciagania, stal nanobainityczna, wytop P1

\begin{tabular}{|c|c|c|c|c|}
\hline $\begin{array}{c}\text { Variant identification } \\
\left(950^{\circ} \mathrm{C} / 30 \mathrm{~min}+\right. \\
\text { cooling in the air })\end{array}$ & $\begin{array}{c}\text { YS } \\
{[\mathrm{MPa}]}\end{array}$ & $\begin{array}{c}T S \\
{[\mathrm{MPa}]}\end{array}$ & $\begin{array}{c}T E \\
{[\%]}\end{array}$ & TS/YS \\
\hline \multirow{3}{*}{$210 / 96$} & 1349 & 2042 & 12.8 & 1.51 \\
\hline & 1440 & 2045 & 14.4 & 1.42 \\
\hline & 1376 & 2055 & 14.0 & 1.49 \\
\hline \multirow{3}{*}{$210 / 120$} & 1525 & 2076 & 12.8 & 1.36 \\
\hline & 1489 & 2067 & 14.4 & 1.39 \\
\hline & 1510 & 2062 & 15.2 & 1.37 \\
\hline \multirow{6}{*}{$215 / 96$} & 1531 & 2050 & 8.8 & 1.34 \\
\hline & 1536 & 2048 & 12.6 & 1.33 \\
\hline & 1453 & 2047 & 9.8 & 1.41 \\
\hline & 1407 & 2087 & 11.8 & 1.48 \\
\hline & 1460 & 2070 & 11.4 & 1.42 \\
\hline & 1474 & 2072 & 11.6 & 1.41 \\
\hline \multirow{3}{*}{$225 / 72$} & 1575 & 1974 & 14.0 & 1.25 \\
\hline & 1355 & 1966 & 13.2 & 1.45 \\
\hline & 1477 & 1961 & 14.2 & 1.33 \\
\hline
\end{tabular}

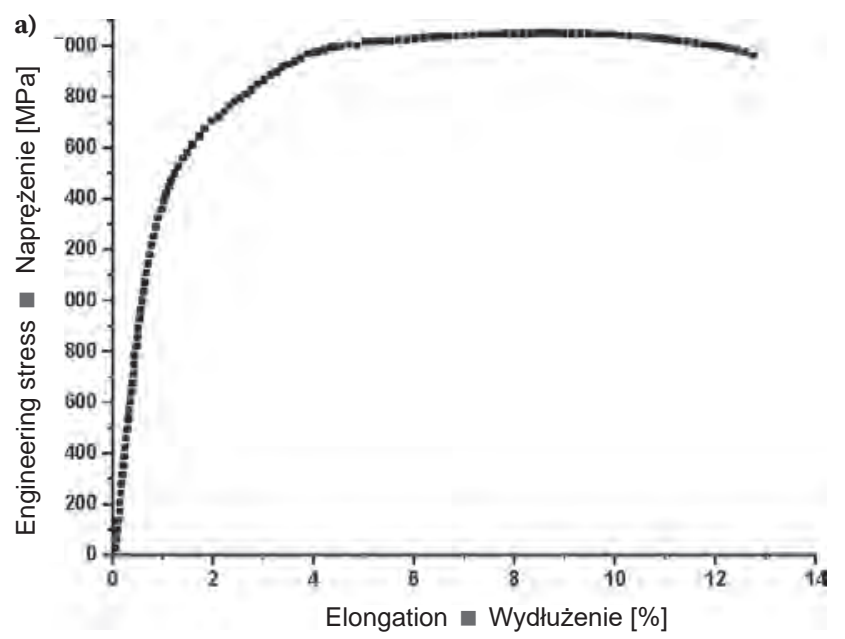

er, a higher elongation of $15 \%$ was obtained. It should be noted that most of the published results of studies on nanobainitic steels are conducted for a material with a higher carbon content, e.g. $0.9 \%$, and a different content of alloying elements. Figs. 13 and 14 present typical tensile curves. The uniaxial compression tests were also carried out in the range of strain rate up to $100 \mathrm{~s}^{-1}$. The test results are presented in Fig. 15. A stress level above $2500 \mathrm{MPa}$ with a strain value up to 0.9 was obtained. During compression, the samples exhibited good ductility and a wide range of deformation hardening. The strength value is analogous to that obtained in [8] for steel with a higher carbon content and similar content of alloying elements.

Table 9. Results of measurement of mechanical properties in static tensile test. Nanobainitic steel, heat P2

Tabela 9. Wyniki pomiarów właściwości mechanicznych w statycznej próbie rozciagania. Stal nanobainityczna, wytop P2

\begin{tabular}{|c|c|c|c|c|}
\hline $\begin{array}{c}\text { Variant identification } \\
\left(950^{\circ} \mathrm{C} / 30 \mathrm{~min}+\right. \\
\text { cooling in the air })\end{array}$ & $\begin{array}{c}\text { YS } \\
{[\mathrm{MPa}]}\end{array}$ & $\begin{array}{c}\text { TS } \\
{[\mathrm{MPa}]}\end{array}$ & $\begin{array}{c}T E \\
{[\%]}\end{array}$ & TS/YS \\
\hline $210 / 48$ & 988 & 2199 & 13.2 & 2.23 \\
\hline $210 / 72$ & 1153 & 2158 & 12.0 & 1.87 \\
\hline \multirow{3}{*}{$210 / 96$} & 1318 & 2040 & 14.0 & 1.55 \\
\hline & 1318 & 2021 & 14.4 & 1.53 \\
\hline & 1349 & 2035 & 15.4 & 1.51 \\
\hline \multirow{3}{*}{$210 / 120$} & 1309 & 1989 & 12.2 & 1.52 \\
\hline & 1425 & 1997 & 15.0 & 1.40 \\
\hline & 1387 & 2000 & 14.2 & 1.44 \\
\hline \multirow{6}{*}{$215 / 96$} & 1316 & 1972 & 14.0 & 1.50 \\
\hline & 1328 & 1991 & 14.4 & 1.50 \\
\hline & 1317 & 1987 & 15.4 & 1.51 \\
\hline & 1371 & 2044 & 12.4 & 1.49 \\
\hline & 1411 & 2044 & 12.9 & 1.45 \\
\hline & 1399 & 2047 & 13.1 & 1.46 \\
\hline \multirow{3}{*}{$225 / 72$} & 1333 & 1959 & 15.0 & 1.47 \\
\hline & 1340 & 1936 & 14.0 & 1.44 \\
\hline & 1357 & 1946 & 15.4 & 1.43 \\
\hline
\end{tabular}

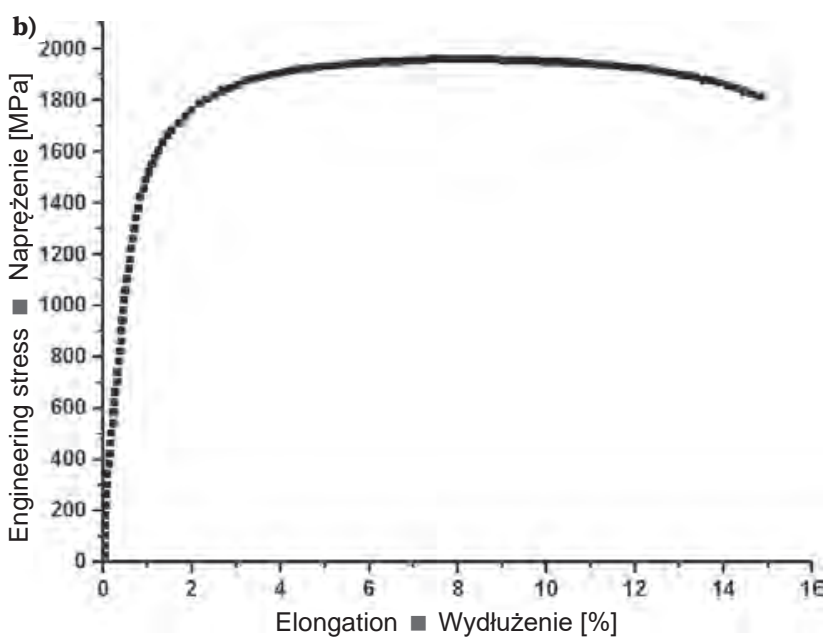

Fig. 13. Typical tensile curves for nanobainitic steel plate samples. Heat P1, a) 210/96; b) 225/72

Rys. 13. Przykładowe krzywe rozciagania próbek z blach ze stali nanobainitycznej. Wytop P1, a) 210/96; b) 225/72 

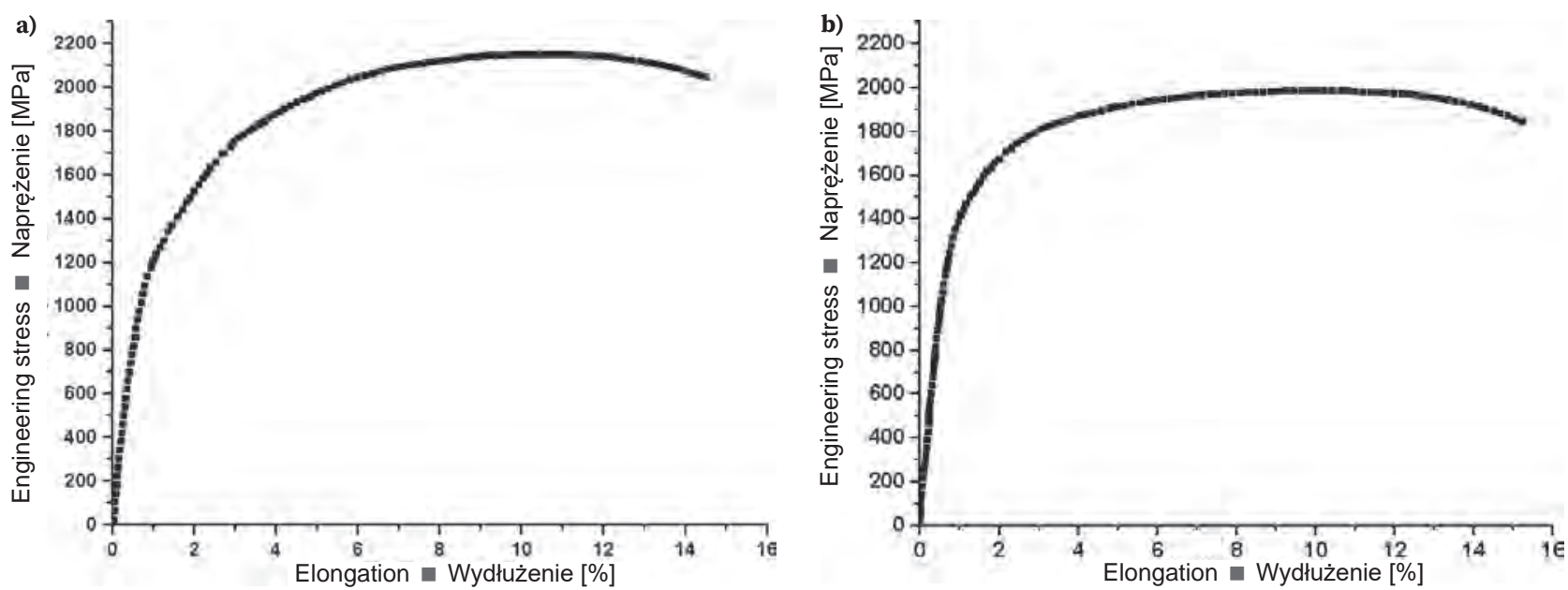

Fig. 14. Typical tensile curves for nanobainitic steel plate. Heat P2, a) 210/72; b) 215/96

Rys. 14. Przykładowe krzywe rozciągania próbek z blach ze stali nanobainitycznej. Wytop P2, a) 210/72; b) 215/96
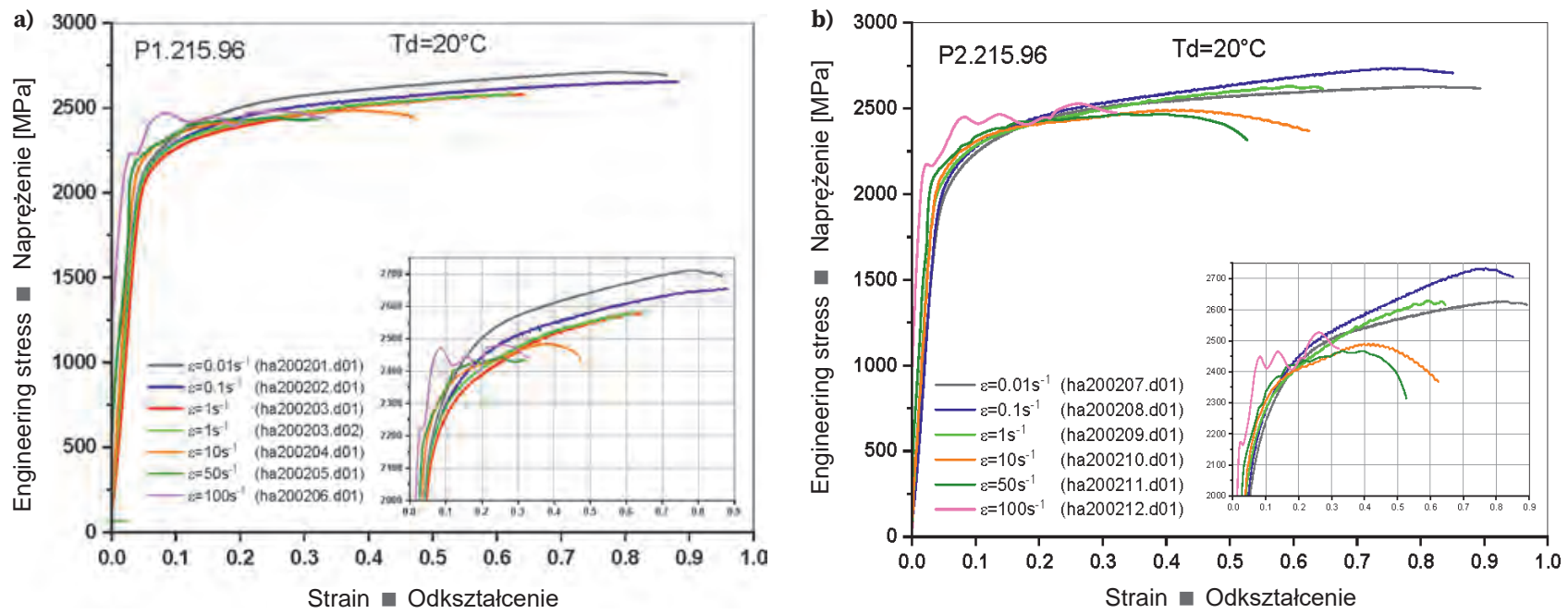

Fig. 15. Compression curves for nanobainitic steel within the strain rate in the range of $0.01-100 \mathrm{~s}^{-1}$. Heat P1 (a) and P2 (b), isothermal annealing parameters $215^{\circ} \mathrm{C} / 96$ hours

Rys. 15. Krzywe ściskania stali nanobainitycznej w zakresie prędkości odkształcenia 0,01-100 s ${ }^{-1}$. Wytop P1 (a) i P2 (b), parametry wygrzewania izotermicznego $215^{\circ} \mathrm{C} / 96$ godzin

Table 10. Charpy-V impact strength measurement results for nanostructured bainitic steel, samples with a cross-section of $10 \times 7.5 \mathrm{~mm}$ The values were calculated for a standard sample size of $10 \times 10 \mathrm{~mm}$ Tabela 10. Wyniki pomiarów udarności Charpy-V stali nanostrukturalnej bainitycznej, próbki o przekroju $10 \times 7,5 \mathrm{~mm}$. Wartości przeliczono dla standardowego wymiaru próbki $10 \times 10 \mathrm{~mm}$

\begin{tabular}{|c|c|c|c|c|c|c|}
\hline $\begin{array}{c}\text { Identification of } \\
\text { heat and HT variant } \\
\text { temp. }\left[{ }^{\circ} \mathrm{C}\right] / \text { time, }[\mathrm{h}]\end{array}$ & $\begin{array}{c}-60^{\circ} \mathrm{C} \\
{[\mathrm{J}]}\end{array}$ & $\begin{array}{c}-40^{\circ} \mathrm{C} \\
{[\mathrm{J}]}\end{array}$ & $\begin{array}{c}-20^{\circ} \mathrm{C} \\
{[\mathrm{J}]}\end{array}$ & $\begin{array}{l}\mathbf{0}^{\circ} \mathbf{C} \\
{[\mathrm{J}]}\end{array}$ & $\begin{array}{c}+20^{\circ} \mathbf{C} \\
{[\mathrm{J}]}\end{array}$ & $\begin{array}{r}+40^{\circ} \mathrm{C} \\
{[\mathrm{J}]}\end{array}$ \\
\hline P1 225/72 & 8 & 11 & 12 & 13 & 19 & 21 \\
\hline P1 215/96 & 9 & 11 & 12 & 16 & 18 & 19 \\
\hline P1 210/96 & 10 & 12 & 14 & 15 & 19 & 20 \\
\hline P2 225/72 & 10 & 11 & 13 & 18 & 21 & 27 \\
\hline P2 215/96 & 9 & 10 & 13 & 17 & 21 & 22 \\
\hline P2 210/96 & 12 & 13 & 15 & 18 & 20 & 22 \\
\hline
\end{tabular}

\subsection{TWO-STAGE ISOTHERMAL TREATMENT}

An alternative method of final heat treatment has been proposed, consisting in isothermal annealing at two tem- peratures successively, which contributes to the improvement of the homogeneity of the properties distribution on the surface of the plate. The reason for the heterogeneity of the properties and microstructure of the plates is primary segregation and the resulting banding of the microstructure. The degree of primary segregation in industrial ingots varies between the "head" and the "foot" and as a result, the obtained plates may differ in quality in terms of material homogeneity. Examples of research and analysis results that were used to develop the heat treatment parameters in industrial conditions are presented below. On the basis of earlier tests, the first treatment temperature was selected at $225^{\circ} \mathrm{C}$, and the second at $210^{\circ} \mathrm{C}$. Times from 6 to 20 hours at $225^{\circ} \mathrm{C}$ and from 89 do 51 hours at $210^{\circ} \mathrm{C}$ were applied. The total transformation time, including the cooling time, as the temperature dropped from $225^{\circ} \mathrm{C}$ to $210^{\circ} \mathrm{C}$, was either 72 or 96 hours. The temperature change from $225^{\circ} \mathrm{C}$ to $210^{\circ} \mathrm{C}$ was carried out in the furnace by reducing the set temperature during approx. 1 hour. Fig. 16 presents transformation kinetics curves for isothermal annealing variants in two temperatures. After heat treatment, the samples were subjected to microstructure examination 


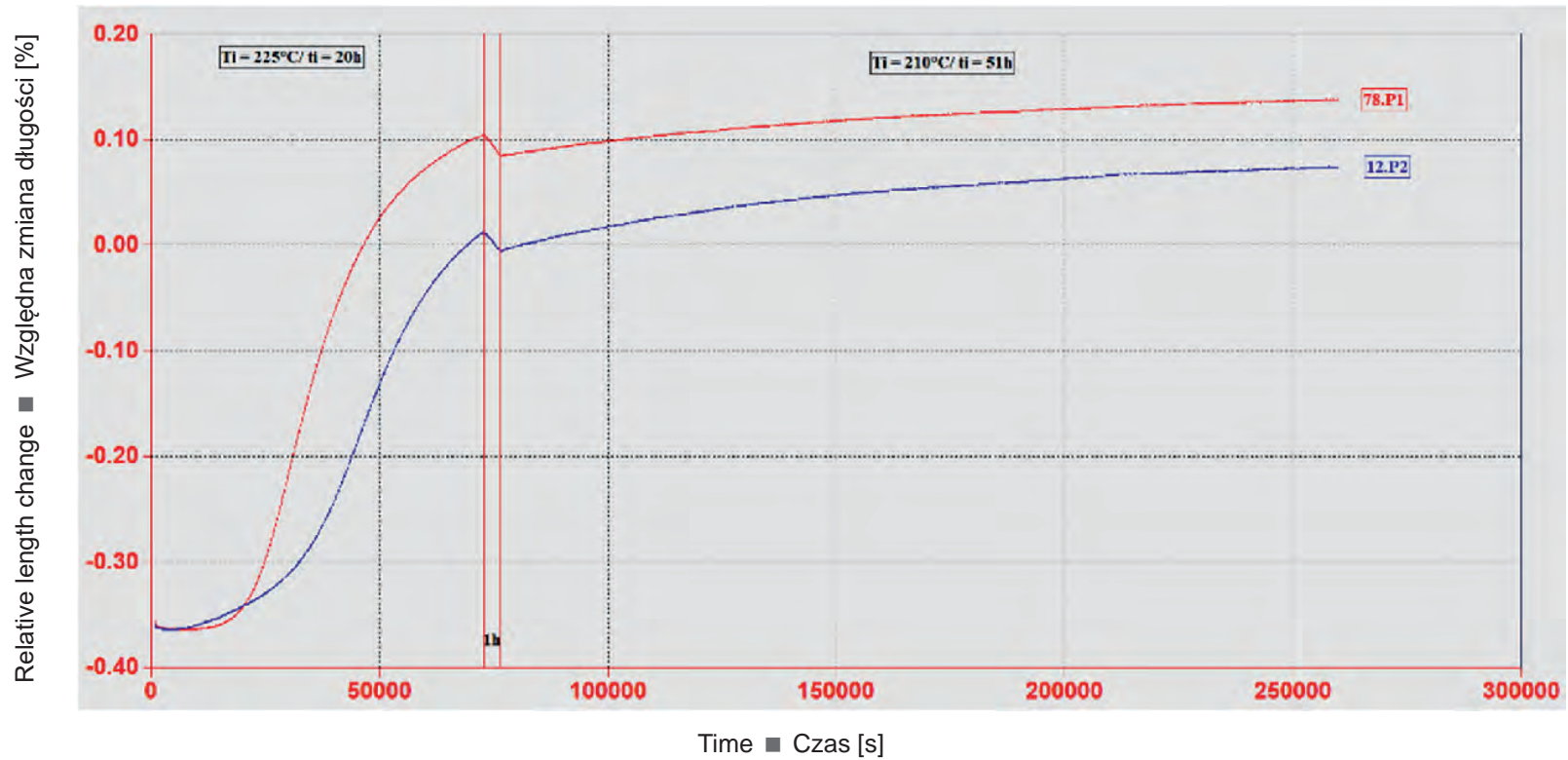

Fig. 16. Changes in the length of the dilatometric sample during annealing at $225^{\circ} \mathrm{C}$ for 20 hours and then at $210^{\circ} \mathrm{C}$ for 51 hours. The cooling time from 225 to $210^{\circ} \mathrm{C}$ was 1 hour. Heat P1 and P2

Rys. 16. Zmiany długości próbki dylatometrycznej w trakcie wygrzewania w temperaturze $225^{\circ} \mathrm{C}$ przez 20 godzin i następnie w $210^{\circ} \mathrm{C}$ przez 51 godzin. Czas chłodzenia od 225 do $210^{\circ} \mathrm{C}$ wynosił 1 godzinę. Wytopy P1 i P2
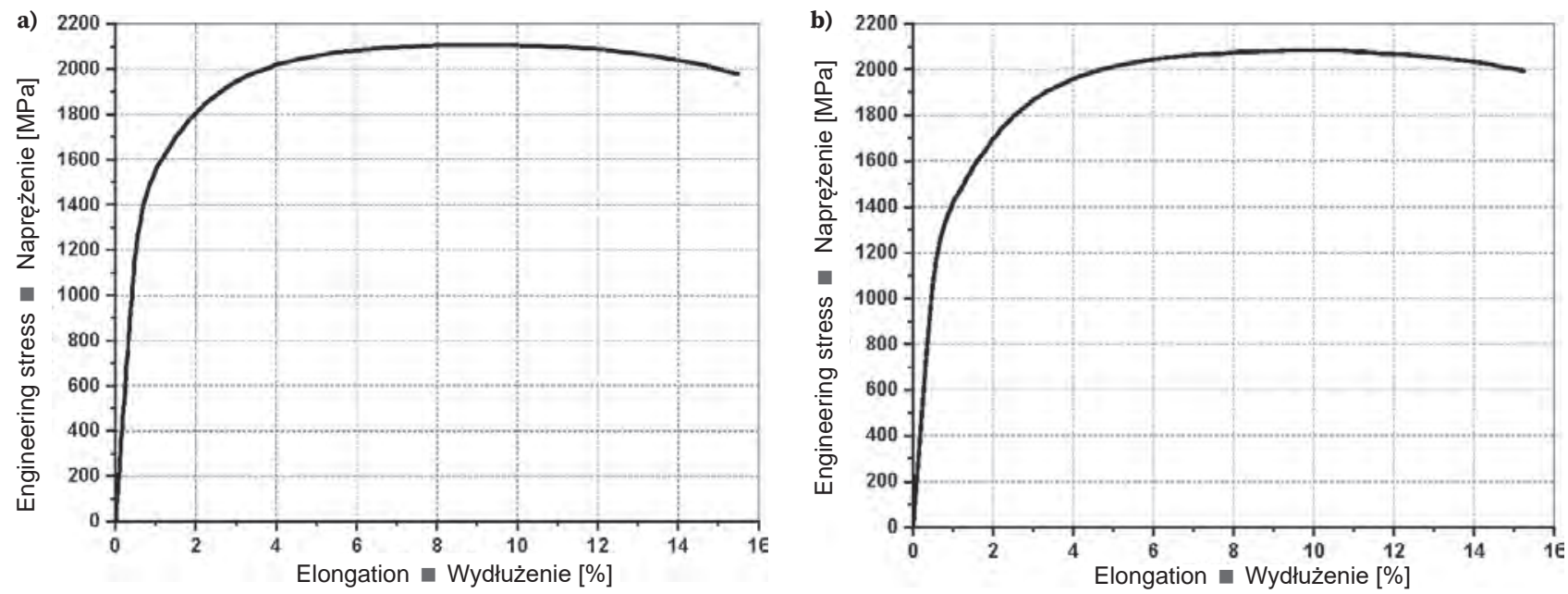

Fig. 17. Typical tensile curves for nanostructured bainitic steel plate. HT: 225/12+210/84; Heat: a) P1, b) P2 Rys. 17. Przykładowe krzywe rozciagania próbek z blach ze stali nanostrukturalnej bainitycznej. 0C: 225/12+210/84; Wytop: a) P1, b) P2
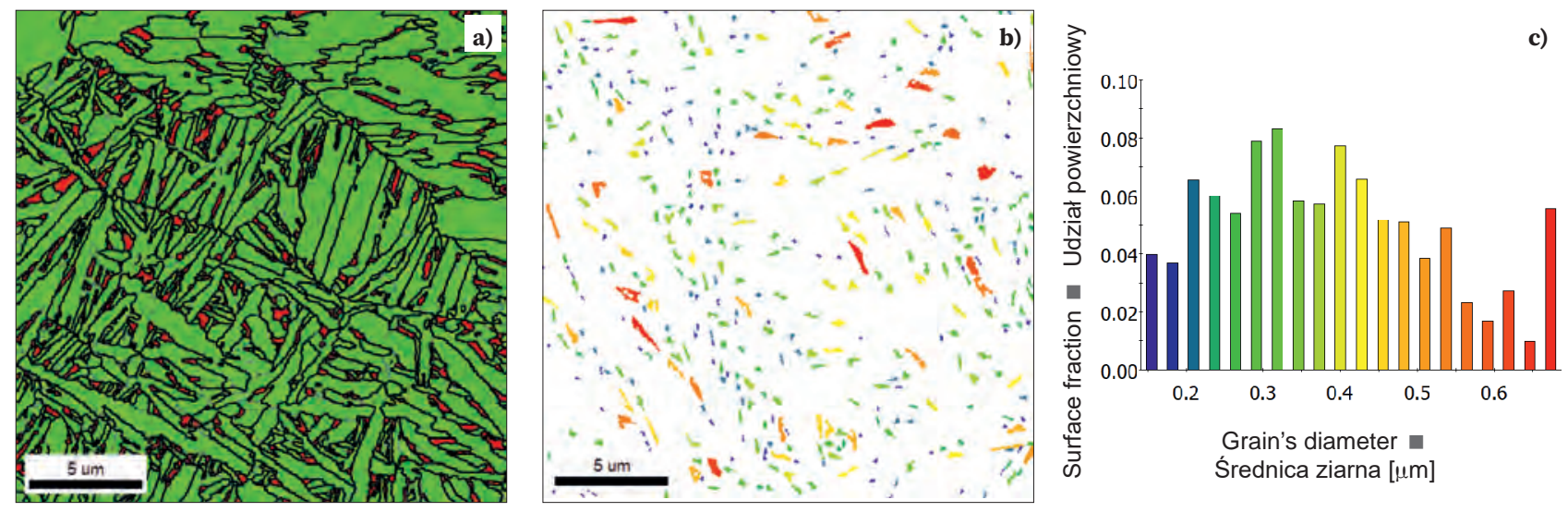

Fig. 18. Results of measurement of size distribution, volume fraction as well as morphology and distribution of blocky retained austenite. Heat P1, variant 225/12+210/84, magn. 5000×, scanning electron microscope, EBSD method. Number of grains $443, d_{\mathrm{av}} 280 \mathrm{~nm}$

Rys. 18. Wyniki pomiarów rozkładu wielkości, ułamka objętości oraz badań morfologii i rozmieszczenia austenitu resztkowego blokowego. Wytop P1, wariant 225/12+210/84, pow. 5000×, skaningowy mikroskop elektronowy, metoda EBSD. Liczba ziaren 443 , $d_{\text {sr }} 280$ nm 
and hardness measurement. The results of the analysis showed the optimal variants of this type of treatment from the point of view of mechanical properties and resistance to perforation. The transformation time at $225^{\circ} \mathrm{C}$ was established to be 12 hours followed by 60 or 84 hours at $210^{\circ} \mathrm{C}$. These variants were subjected to further microstructure and mechanical properties tests, and the plates were prepared for firing tests. The results of testing the mechanical properties of samples after isothermal annealing at two temperatures are presented in Table 11, and Table 12 presents the results of impact strength measurement. Figures 17 and 18 present typical results of the examination of properties and microstructure. The comprehensive analysis of the test results indicated the final parameters to be used in the technology of heat treatment of plates in industrial conditions.

Table 11. Results of measurement of mechanical properties in static tensile test $T$ and $t$ - temperature and isothermal annealing time, respectively; austenitising parameters: $950^{\circ} \mathrm{C} / 30$ minutes

Tabela 11. Wyniki pomiarów właściwości mechanicznych w statycznej próbie rozciagania. $T$ i $t$ - odpowiednio temperatura i czas wygrzewania izotermicznego, parametry austenityzowania: $950^{\circ} \mathrm{C} / 30$ minut

\begin{tabular}{|c|c|c|c|c|c|}
\hline $\begin{array}{c}\text { Variant } \\
\text { identification } \\
\text { T1.t1+T2.t2 } \\
\text { T, }\left[{ }^{\circ} \mathrm{C}\right] ; \mathrm{t},[\mathrm{h}]\end{array}$ & $\begin{array}{c}\text { Sample } \\
\text { thickness, } \\
\text { [mm] }\end{array}$ & $\begin{array}{c}Y S \\
{[\mathrm{MPa}]}\end{array}$ & $\begin{array}{c}T S \\
{[\mathrm{MPa}]}\end{array}$ & $\begin{array}{c}T E \\
{[\%]}\end{array}$ & TS/YS \\
\hline \multicolumn{6}{|c|}{ P1 } \\
\hline $225.6+210.90$ & 8.73 & 1350 & 2067 & 13.7 & 1.53 \\
\hline $225.6+210.90$ & 8.73 & 1333 & 2087 & 13.2 & 1.57 \\
\hline $225.6+210.90$ & 8.73 & 1378 & 2064 & 13.3 & 1.50 \\
\hline $225.12+210.60$ & 8.87 & 1395 & 2101 & 11.1 & 1.51 \\
\hline $225.12+210.60$ & 8.73 & 1290 & 2117 & 11.3 & 1.64 \\
\hline $225.12+210.60$ & 8.77 & 1320 & 2108 & 11.1 & 1.60 \\
\hline $225.12+210.84$ & 8.76 & 1451 & 2105 & 11.3 & 1.45 \\
\hline $225.12+210.84$ & 8.76 & 1453 & 2112 & 11.1 & 1.45 \\
\hline $225.12+210.84$ & 8.77 & 1469 & 2124 & 11.3 & 1.45 \\
\hline \multicolumn{6}{|c|}{ P2 } \\
\hline $225.6+210.90$ & 8.63 & 1280 & 2063 & 14.2 & 1.61 \\
\hline $225.6+210.90$ & 8.63 & 1291 & 2060 & 13.7 & 1.60 \\
\hline $225.6+210.90$ & 8.64 & 1320 & 2064 & 14.0 & 1.56 \\
\hline $225.12+210.60$ & 8.82 & 1230 & 2118 & 11.8 & 1.72 \\
\hline $225.12+210.60$ & 8.82 & 1223 & 2104 & 10.2 & 1.72 \\
\hline $225.12+210.84$ & 8.83 & 1320 & 2086 & 13.1 & 1.58 \\
\hline $225.12+210.84$ & 8.83 & 1358 & 2077 & 13.3 & 1.53 \\
\hline
\end{tabular}

Table 12. Charpy-V impact strength measurement results for nanostructured bainitic steel, samples with a cross-section of $10 \times 7.5 \mathrm{~mm}$. The values were calculated for a standard sample size of $10 \times 10 \mathrm{~mm}$

Tabela 12. Wyniki pomiarów udarności Charpy-V stali nanostrukturalnej bainitycznej, próbki o przekroju $10 \times 7,5 \mathrm{~mm}$. Wartości przeliczono dla standardowego wymiaru próbki $10 \times 10 \mathrm{~mm}$

\begin{tabular}{|c|c|c|}
\hline $\begin{array}{c}\text { Identification of heat and } \mathbf{H T} \text { variant } \\
\text { temp. }{ }^{\circ} \mathbf{C} / \text { time, } \mathbf{h}\end{array}$ & $\begin{array}{c}+\mathbf{2 0}^{\circ} \mathbf{C} \\
{[\mathbf{J}]}\end{array}$ & $\begin{array}{c}-\mathbf{4 0} \\
{[\mathbf{J}]}\end{array}$ \\
\hline $\mathrm{P} 1225.12+210.84$ & 19 & 11 \\
\hline $\mathrm{P} 2225.12+210.84$ & 22 & 14 \\
\hline
\end{tabular}

\subsection{FIRING TEST RESULTS FOR INDUSTRIAL MATERIAL AFTER HEAT TREATMENT IN LABORATORY FURNACES}

The results of the firing tests were a key stage of the verification of the applied plate production technology parameters. In the field of final heat treatment, based on the results of microstructure tests, measurement of mechanical properties and the results of firing tests, the range of temperature and time of isothermal annealing was determined, after which plates made of nanobainitic steel with a thickness of 7.5-8.5 $\mathrm{mm}$ show resistance to perforation under the conditions of firing according to STANAG 4569 level 2. In the first stage, the research material consisted of industrial scale plates, which were subjected to various parameters of isothermal annealing in laboratory conditions. Based on the results of firing tests with the first series, variant P1.215.96 was selected. The plate with a nominal thickness of $8.5 \mathrm{~mm}$ made of this material fulfilled the firing test with a $7.62 \times 39 \mathrm{API} \mathrm{BZ}$ ammunition at an angle of $0^{\circ}$, in the entire velocity range specified in Stanag 4569 - level 2 $(695-715 \mathrm{~m} / \mathrm{s})$ and additionally at velocities significantly higher than the upper limit according to the above-mentioned document, amounting to 757 and $775 \mathrm{~m} / \mathrm{s}$. For the second series of firing tests, $\mathrm{P} 1$ and $\mathrm{P} 2$ heat plates were prepared with a wider range of parameters of the final heat treatment. Very good protection properties were demonstrated for the P2 heat plates. The requirements for level 2 according to Stanag 4569 were met by plates with a nominal thickness of $7.5 \mathrm{~mm}$ in three heat treatment variants (210.96; 215.96 and 225.72). In addition, these plates exhibited resistance to perforation with a $7.62 \times 39 \mathrm{~mm}$ shell $\left(0^{\circ}\right.$ angle) for a velocity of $765 \mathrm{~m} / \mathrm{s}$. In the second series of tests, the positive result obtained in the first series was confirmed for $8.5 \mathrm{~mm}$ plate from the $\mathrm{P} 1$ heat in the 215.96 variant, and additionally for this material, a positive result was obtained for the $8.5 \mathrm{~mm}$ thick plate in the 210.96 variant.

$500 \times 500 \mathrm{~mm}$ plates from heat P2 were prepared for the third series of firing tests. Heat treatment with the use of a furnace and a fan cooling system was carried out for these plates. The use of a fan may have the effect of surface cooling of a thin layer of material, including scale, as a result of which the temperature of the centre of the plate is higher than that measured on the surface with an optical pyrometer. Then, there is a risk of the formation of upper bainite when the temperature of isothermal annealing is reached, which is particularly unfavourable if it separates at grain boundaries of former austenite. Disparity of the plates' properties on the surface was found. There was perforation in a specific zone of the plate, and in the second part the test results were positive, also for the highest possible velocity for the $7.62 \times 39 \mathrm{~mm}$ API BZ ammunition. For example, in the area of one $500 \times 500 \mathrm{~mm}$ plate, for the velocity of $746 \mathrm{~m} / \mathrm{s}$, the test was positive, and for the velocity of $696 \mathrm{~m} / \mathrm{s}$, it was negative. In the third series of tests, a positive test result was obtained by firing at a plate with a thickness of $6.6 \mathrm{~mm}$ P2.215.96 at an angle of $30^{\circ}$ in accordance with the requirements for Stanag 4569 level 2. It was assumed that the cooling of the plates after austenitisation would be carried out in the air, the more so as the alloying content of P2 steel ensures sufficient hardenability (critical cooling rate) for the correct implementation of the plate manufacturing process. Fig. 19 presents the photographs of nanobainitic steel plates after firing. 

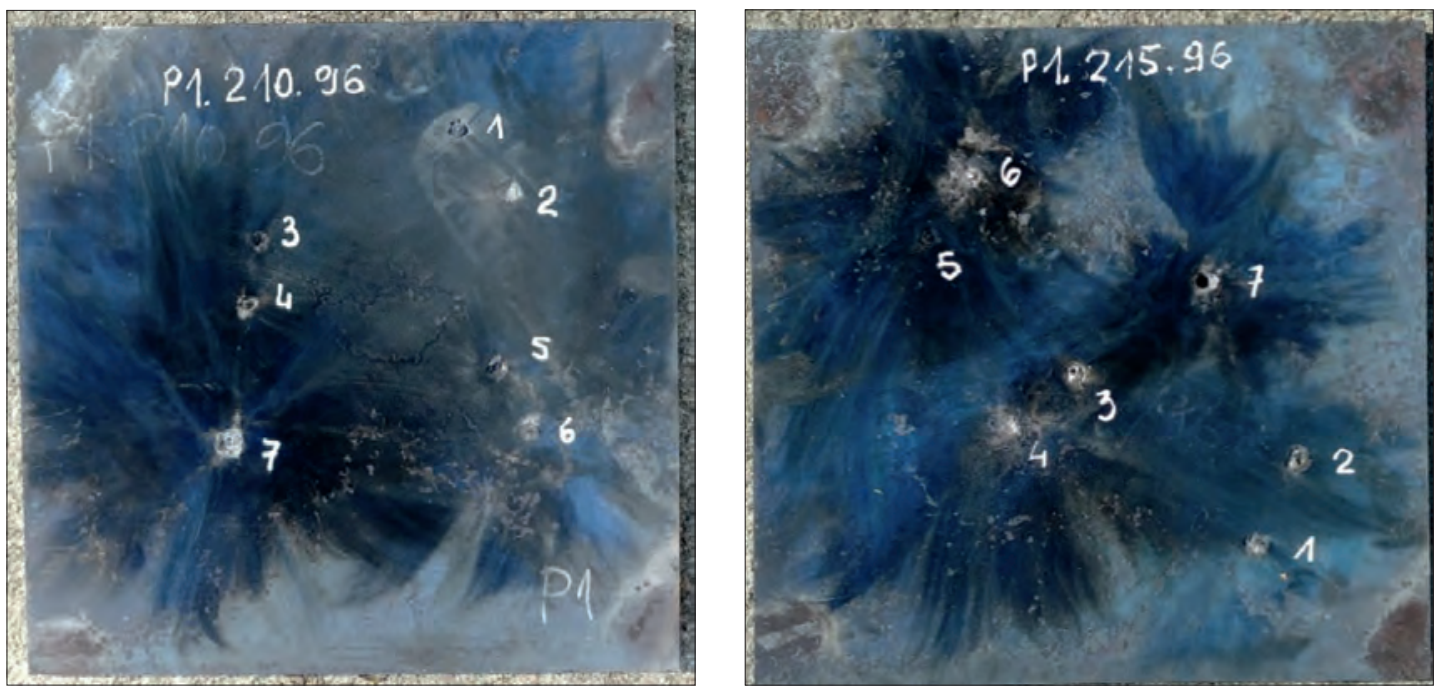

Fig. 19. Photographs of plates after firing with a $7.62 \times 39 \mathrm{~mm}$ BZ ammunition, heat $P 1$, thickness $8.5 \mathrm{~mm}$ Rys. 19. Fotografie blach po ostrzale za pomocą amunicji kal. 7,62×39 mm BZ, wytop P1, grubość 8,5 mm

Results of microstructure examination within projectile impact areas

The study of the microstructure in the area of the projectile impact was performed in order to determine in detail the penetration depth and material characteristics in the form of microcracks, shear bands, etc. Such tests provide additional information in terms of, for example, the margin of safety that a given material variant exhibits. Fig. 20 presents the results of macro- and microstructure examination within the projectile impact areas. Shear bands and
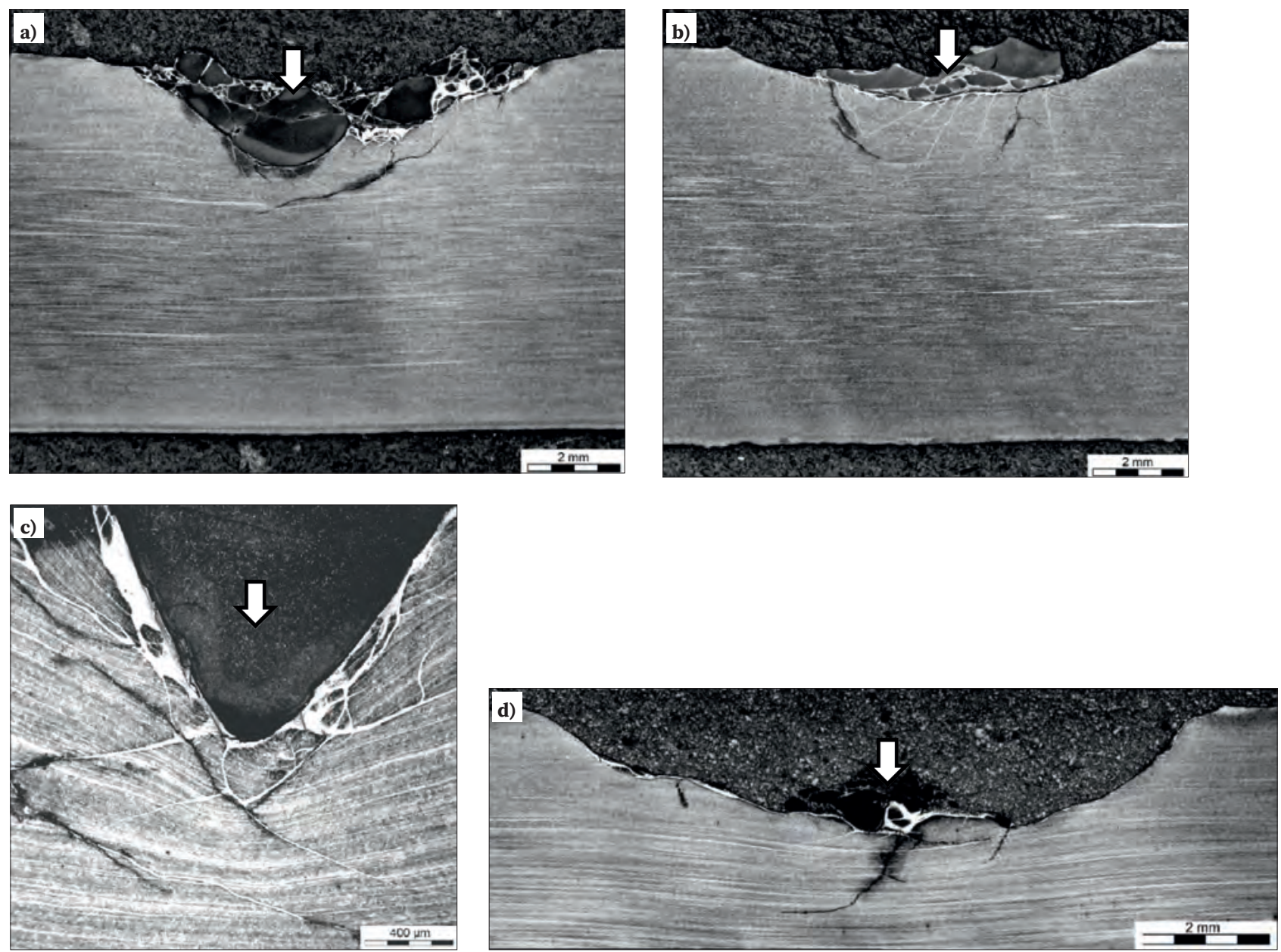

Fig. 20. Microstructure within the area of $7.62 \times 39 \mathrm{~mm}$ API BZ projectile core impact on the plate; a) P2.225.12+210.60, plate thickness 8.3 mm; b) P1.225.12+210.84, plate thickness $9.0 \mathrm{~mm}$, c) P1.210.96, plate thickness $8.5 \mathrm{~mm}$, d) P2.210.96, plate thickness 7.5 mm

Rys. 20. Makrostruktura w obszarach uderzenia rdzenia pocisku 7,62×39 mm API BZ w blachę; a) P2.225.12+210.60, grubość blachy 8,3 mm, b) P1.225.12+210.84, grubość blachy $9,0 \mathrm{~mm}$, c) P1.210.96, grubość blachy 8,5 mm, d) P2.210.96, grubość blachy 7,5 mm 
cracks formed as a result of the firing were observed. There were also cracks with a characteristic curve in the direction parallel to the banding of the plate's microstructure. As part of the quality assessment, the hardness distribution in the thickness of the plates, which successfully passed the firing tests, was determined. The results of this measurement showed that in the subsurface zone with a depth of approx. $0.3 \mathrm{~mm}$, the hardness decreased to approx. $500 \mathrm{HV}$, and in the remaining part the hardness was from 600 to $630 \mathrm{HV}$. Asymmetrical hardness distribution was observed along the plate's thickness. From one surface of the plates to a depth reaching half the thickness, the hardness was in the range of $600-610 \mathrm{HV}$, and on the other surface, the hardness was higher - in the range of 620-630 HV. The reason for this phenomenon could be one-sided decarburisation of the plate during the manufacturing process, e.g. during long-term soft annealing. The results of the effect assessment of the firing showed a positive reaction of nanobainitic steel to high-energy impact. The research showed the occurrence of various depths of penetration, among others due to the typical heterogeneity of the material and the uniqueness of some parameters of the firing tests, including the alignment impact of the core, its shape and mass.

The test panels were subjected to ballistic tests. For the first series, panels were prepared that reflect the critical structural nodes of the container from the point of view of protective capacity. The armour of the panels consisted of nanobainitic steel plates from P1 and P2 heats, heat treated in the conditions of Łukasiewicz - IMŻ. As a result of the firing, the vast majority of tests were positive, including tests using a projectile velocity higher than the required one. There were single negative tests resulting from a local change in material properties caused by heterogeneity (primary segregation). For this purpose, additional firing tests were performed with the use of aramid laminate used as additional protection in the case when the base armour material meets the protective requirements, but there are single negative tests and/or borderline cases, e.g. in the form of secondary shrapnel. Table 13 presents firing

Table 13. Firing test results for experimental panels. Series 1

Tabela 13. Przykładowe wyniki testów ostrzałem paneli eksperymentalnych. Seria 1

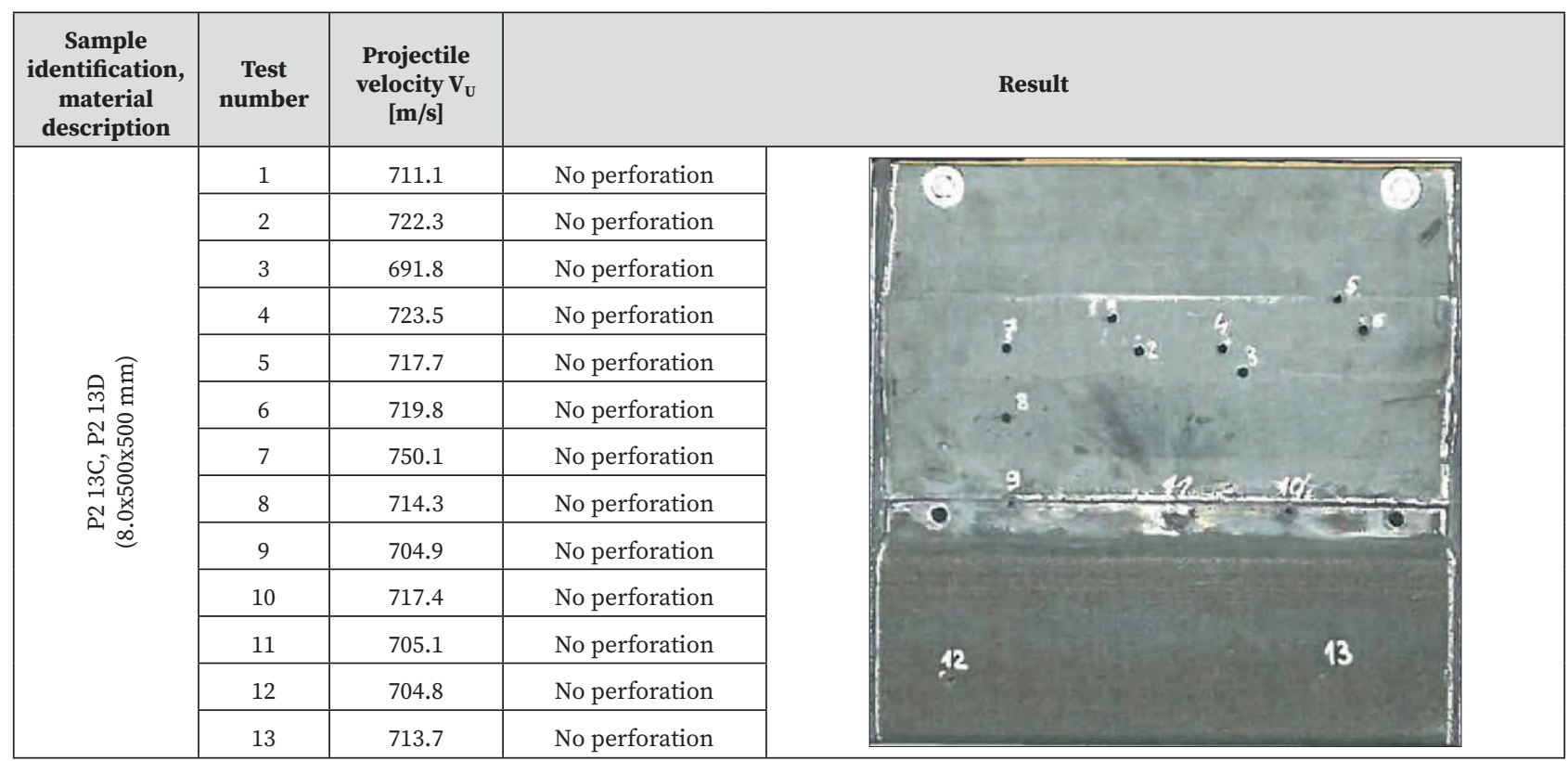

Table 14. Firing test results for experimental panels. Series 2

Tabela 14. Przykładowe wyniki testów ostrzałem paneli eksperymentalnych. Seria 2

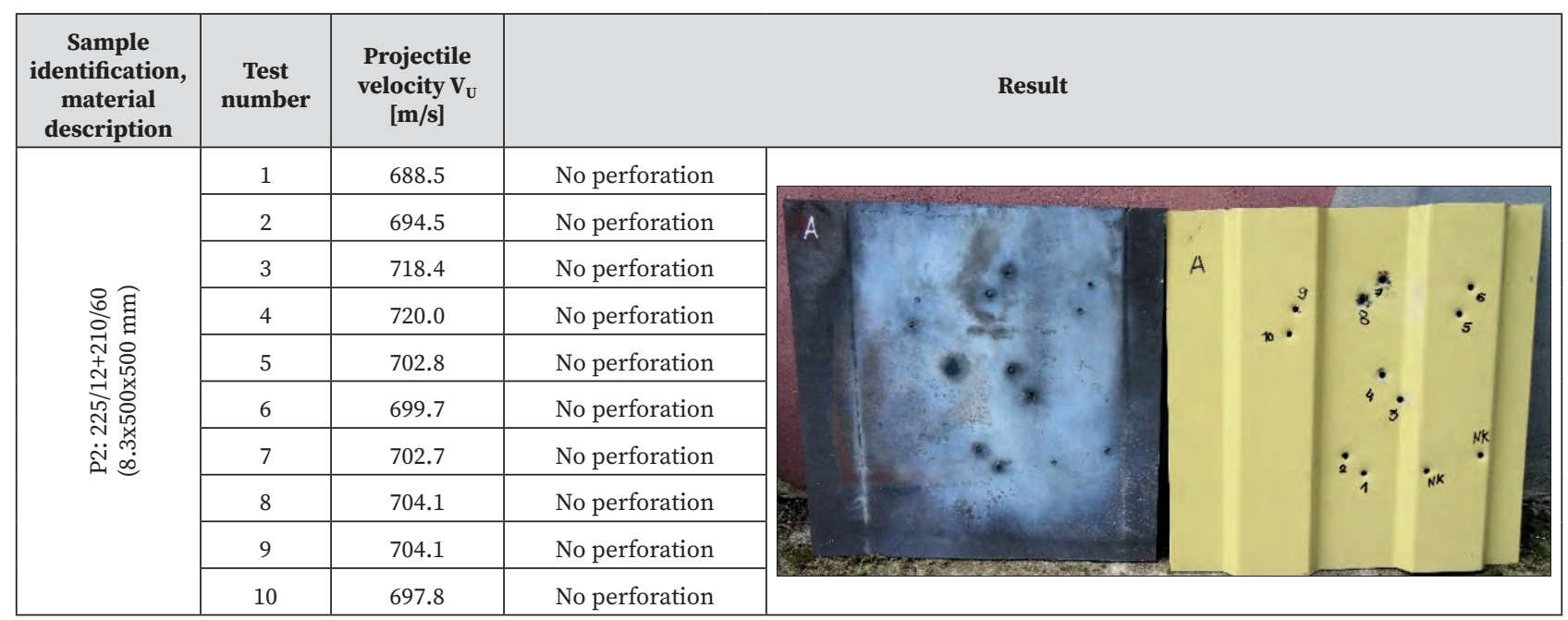


test results and photographs of panels after testing. In the second series, the systems simulating the container walls with the use of armour made of nanobainitic plates, which were heat treated with modified parameters, were tested (Table 14). Contrary to the research conducted so far, a significant change was introduced in the final heat treatment technology and it was carried out at two temperatures with experimentally selected annealing time in each of them. The firing test results showed an improvement in protective parameters. In the vast majority of multi-hit firing tests, the requirements specified in Stanag 4569 for level 2 were met in $100 \%$.

\section{RESULTS OF RESEARCH ON THE MICROSTRUCTURE AND PROPERTIES OF NANOBAINITIC STEEL PLATES PRODUCED IN A FULL INDUSTRIAL PROCESS}

The examination of the microstructure of test samples heat-treated in industrial conditions was carried out on the cross-sectional areas of the parts of the samples after tensile tests. Fig. 21 shows the microstructure images of the subsurface layer of the samples observed with a light microscope. Incomplete decarburisation to a depth of $0.12-0.15 \mathrm{~mm}$ was observed, which resulted in the formation of a different type of microstructure (lathy bainite and acicular ferrite) than nanobainite in this layer. Total decarburisation, which results in the formation of preutectoid ferrite, is in the form of single ferrite grains (Fig. 21a) or in places - a continuous thin ferrite layer with a thickness not exceeding 25-30 $\mu \mathrm{m}$ (Fig. 21b). Subsurface layer fragments not exhibiting complete decarburisation were also observed. When comparing the subsurface microstructure of the test samples with that of heat-treated plates with these samples, it should be taken into account that the surfaces of the samples were ground before heat treatment, while the surfaces of the plates were not cleaned or machined. The images of microstructure in the central area of the cross-section are presented in Fig. 22. Based on light microscopic observation of the microstructure of P1 and P2 steel samples heat-treated in an industrial process in sets together with the plates, the following conclusions can be drawn:
- The type of microstructure is correct for all tested variants - with slight deviations unavoidable in the industrial process, i.e. nanobainite is the matrix, and the remaining phase components are retained austenite in granular (block) form and - in some variants - traces of martensite lath (retained austenite less than approx. $0.5 \mu \mathrm{m}$ cannot be identified using light microscopy).

- The microstructure is characterised by moderate banding, resulting from the segregation of alloying elements inherited at individual technological stages, formed during solidification of the steel; in light bands (with a higher concentration of elements) there is a higher content of retained austenite, and in darker bands (with a lower concentration of elements), in some variants, individual martensite laths were formed, due to the higher than the average $M_{\mathrm{S}}$ temperature for steel.

- There was no clear correlation between the microstructure features observed with a light microscope and the established differences in mechanical properties. This shows that the analysed small differences in the mechanical properties of the P1 and P2 steel plates presented in Table 15 depend on the parameters distinguishable in the nanoscale, such as the proportion of the amounts of individual morphological types of retained austenite and the dimensions and substructure of bainitic ferrite nanolaths as well as the form and distribution of carbon in retained austenite and bainitic ferrite.

For scanning electron microscope (SEM) studies, samples were selected that represent the morphological features of the microstructure in light microscopy studies. Images produced in SEM with the use of secondary electrons (SE - secondary electrons - images) show mainly the surface morphology - in this case, an etched relief derived from microstructure components - and therefore do not contain information on phase composition [19]. It was confirmed by comparative studies that with the SEM imaging method, also using the BSE - back scattered electrons method, it is not possible to unequivocally identify areas of retained austenite. This shows that the grains of blocky retained austenite cannot be distinguished in the SEM images presented in Fig. 23. The SEM-SE images reveal the detailed structure of the steel matrix in the form of bainitic ferrite nanolath packets and sporadically occurring mar-
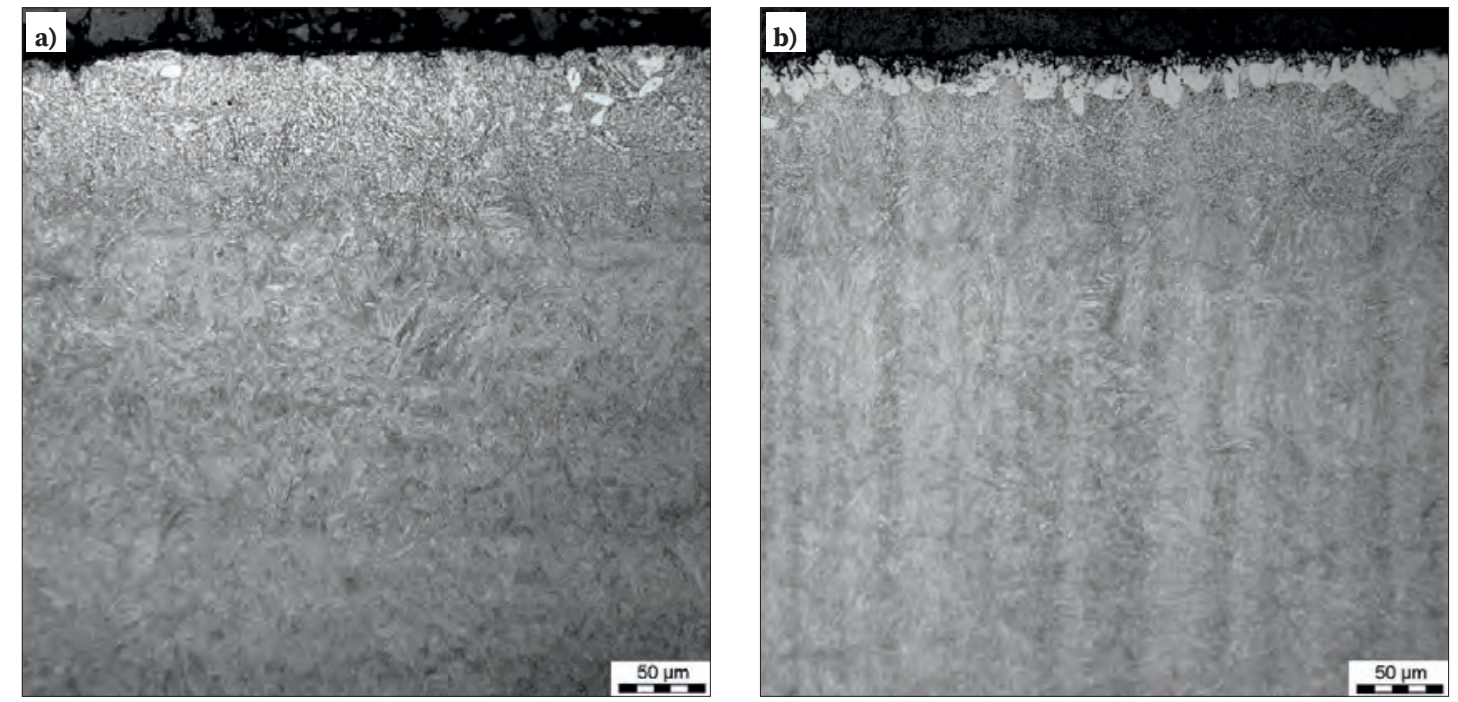

Fig. 21. Microstructure of the subsurface layer of heat-treated test samples with plate sets; a) P1 heat, b) P2 heat, light microscope Rys. 21. Mikrostruktury przypowierzchniowej warstwy próbek testowych obrobionych cieplnie z pakietami blach; a) wytop P1, b) wytop P2, mikroskop świetlny 

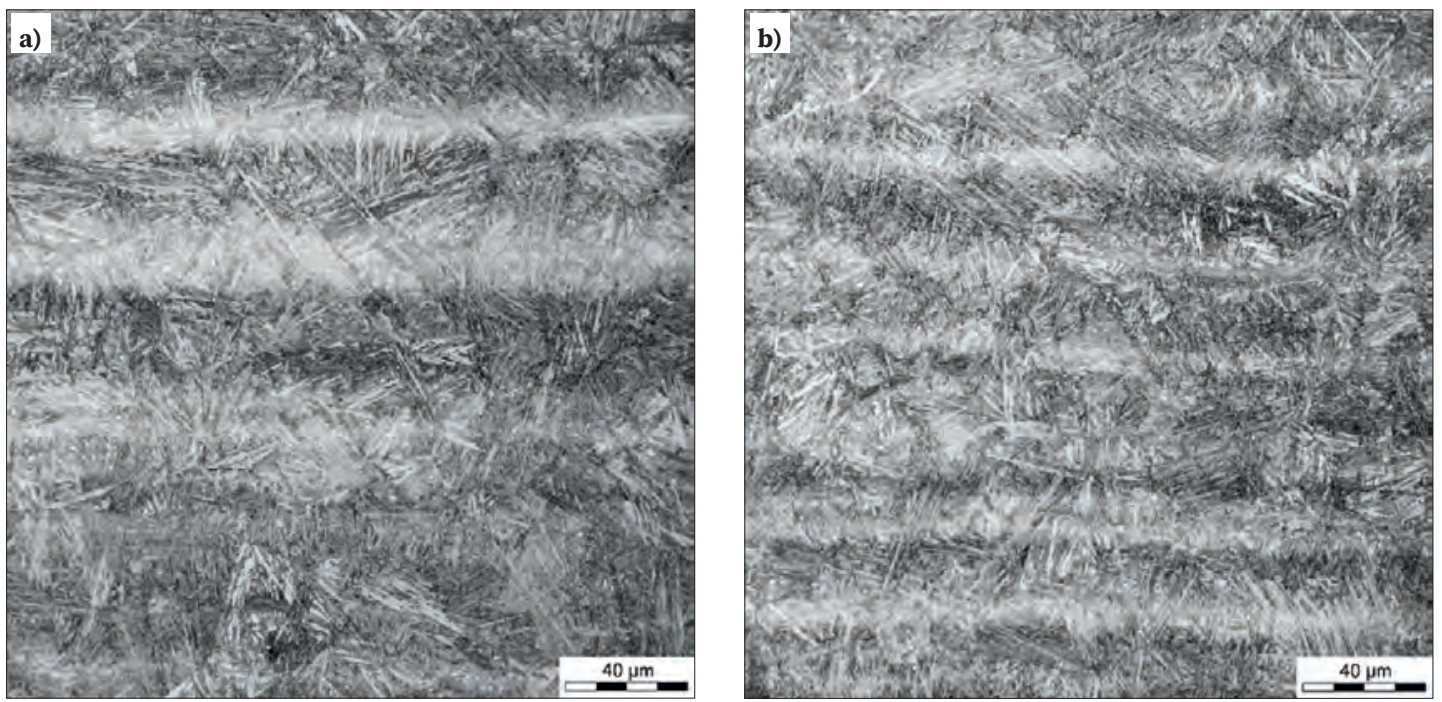

Fig. 22. Microstructures of central area in the cross-section of test samples, heat-treated with plate sets, P1 heat; light microscope Rys. 22. Mikrostruktury środkowego obszaru na przekroju poprzecznym próbek testowych obrobionych cieplnie z pakietami blach, wytop P1; mikroskop świetlny
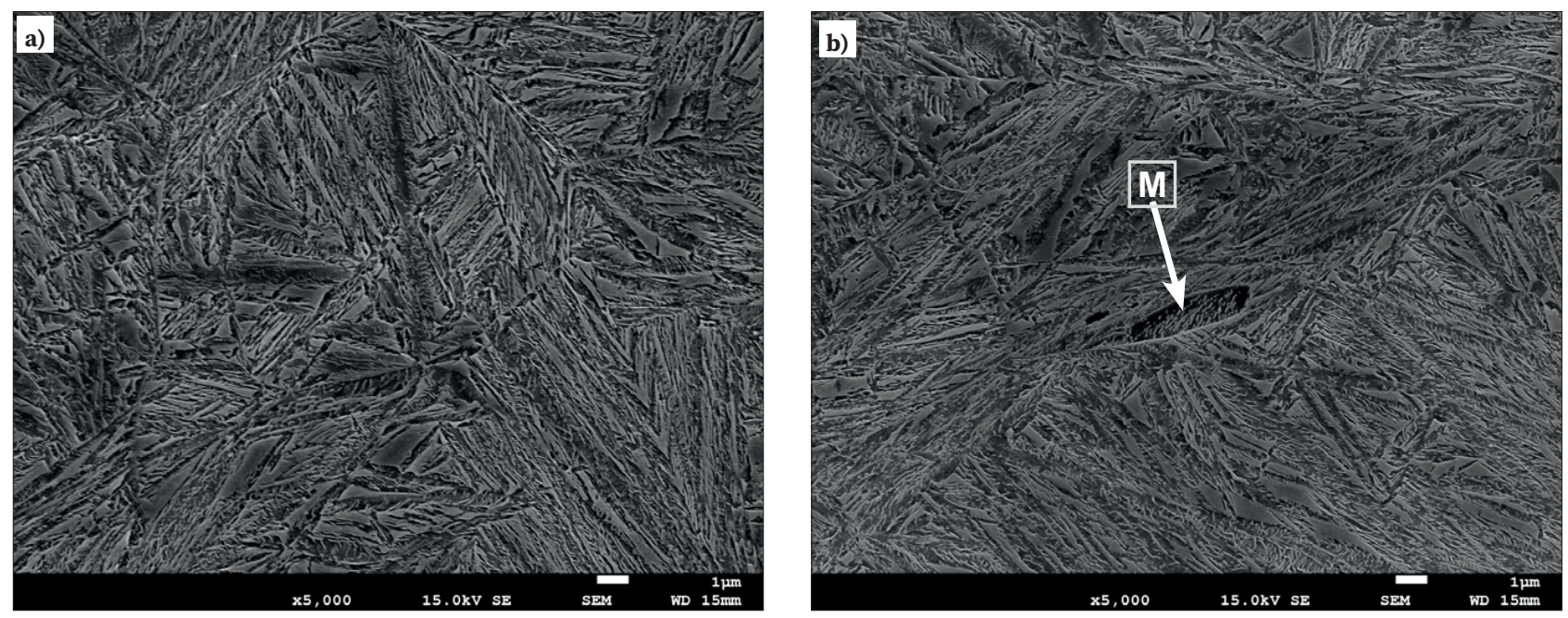

Fig. 23. Microstructures of central area in the cross-section of test samples, heat-treated with plate sets, scanning microscope, SEM-SE images; a) heat P2, b) heat P1

Rys. 23. Mikrostruktury środkowego obszaru na przekroju poprzecznym próbek testowych obrobionych cieplnie z pakietami blach, mikroskop skaningowy, obrazy SEM-SE; a) wytop P2, b) wytop P1

tensite laths (examples in Fig. 23b, marked as M). In some segregation areas with increased content of alloying elements, fine particles of undissolved carbides were found. In the tested samples, no high-temperature phase transformation products, such as upper bainite or pearlite, were found. The achieved microstructure type is analogous to the test results published in [6].

In order to verify that the microstructure of the test material (from the grip part of tensile samples) is representative of the microstructure of heat-treated plates in industrial conditions, samples were cut from P2 steel plates with a thickness of: $6.8 \mathrm{~mm}, 8.3 \mathrm{~mm}$ and $9.0 \mathrm{~mm}$ and tests were performed using a scanning electron microscope. Typical SEM images of the mentioned plate samples are presented in Fig. 24. The comparison of the microstructure of samples cut from plates with the microstructure of test strength samples heat treated together with the plates shows that the microstructure of tensile samples is made of identical bainitic ferrite nanolath packets as the matrix of microstructure of plates randomly selected for the testing, and the number of individual martensite laths and areas containing undissolved carbide particles and the sizes of these particles are very close to the morphological parameters of the microstructure observed in the micrographs of strength samples. On this basis, it was assumed that the tensile samples represent the microstructure and mechanical properties of the plates processed with these samples in individual sets.

Fig. 25 shows the SEM images covering the edges of the P2 steel plate heat-treated in industrial conditions, illustrating the depth of decarburisation. Total (complete) decarburisation, resulting in the formation of preutectoid ferrite grains, is small - it reaches a depth of approx. $50-60 \mu \mathrm{m}$ and is approximately twice as large as the complete decarburisation of ground strength samples, which was assessed at 25-30 $\mu \mathrm{m}$. The depth of incomplete decarburisation, reaching the point where the average hardness of the steel core is obtained, for a plate with a thickness 

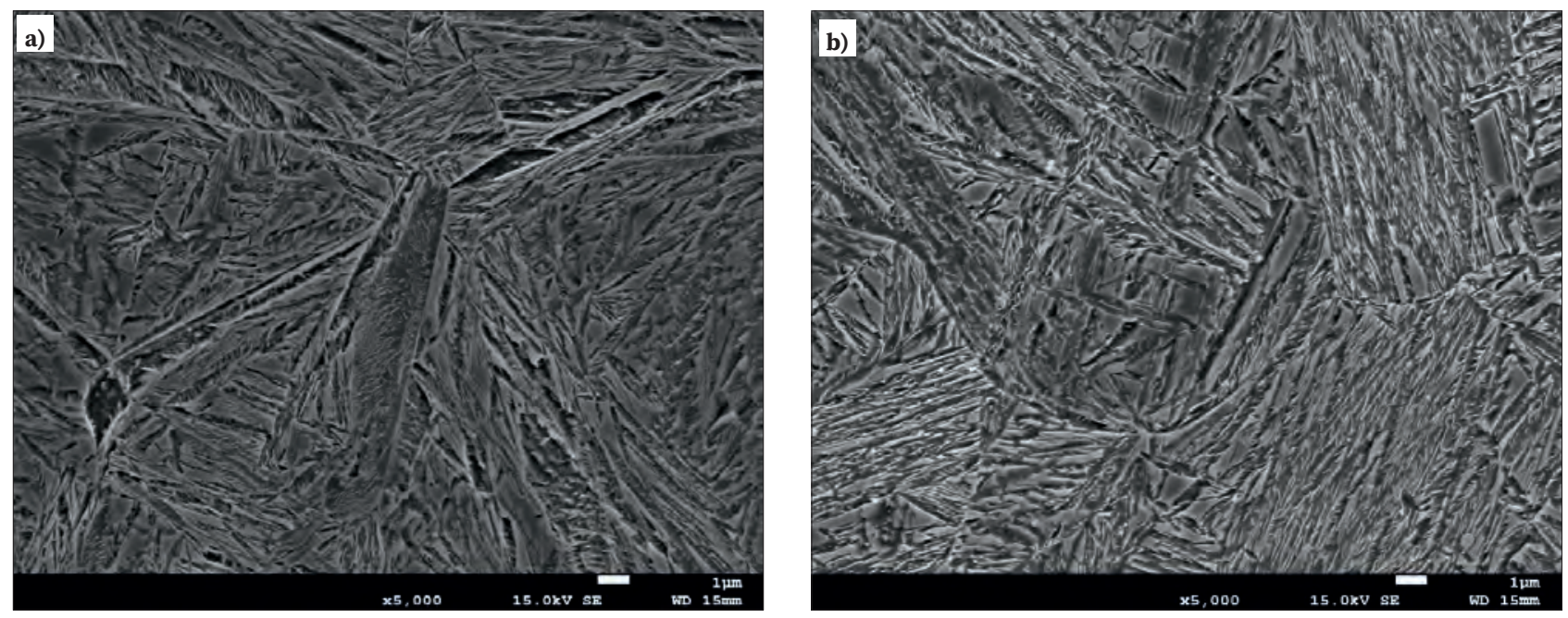

Fig. 24. Microstructures of central area on the cross-section of samples cut from P2 steel plates heat-treated under industrial conditions; a) plate thickness $6.8 \mathrm{~mm}$; b) plate thickness $8.3 \mathrm{~mm}$; scanning electron microscope

Rys. 24. Mikrostruktury środkowego obszaru na przekroju poprzecznym próbek wyciętych z blach ze stali P2 obrobionych cieplnie w warunkach przemysłowych; a) grubość blachy 6,8 mm; b) grubość blachy 8,3 mm; mikroskop skaningowy
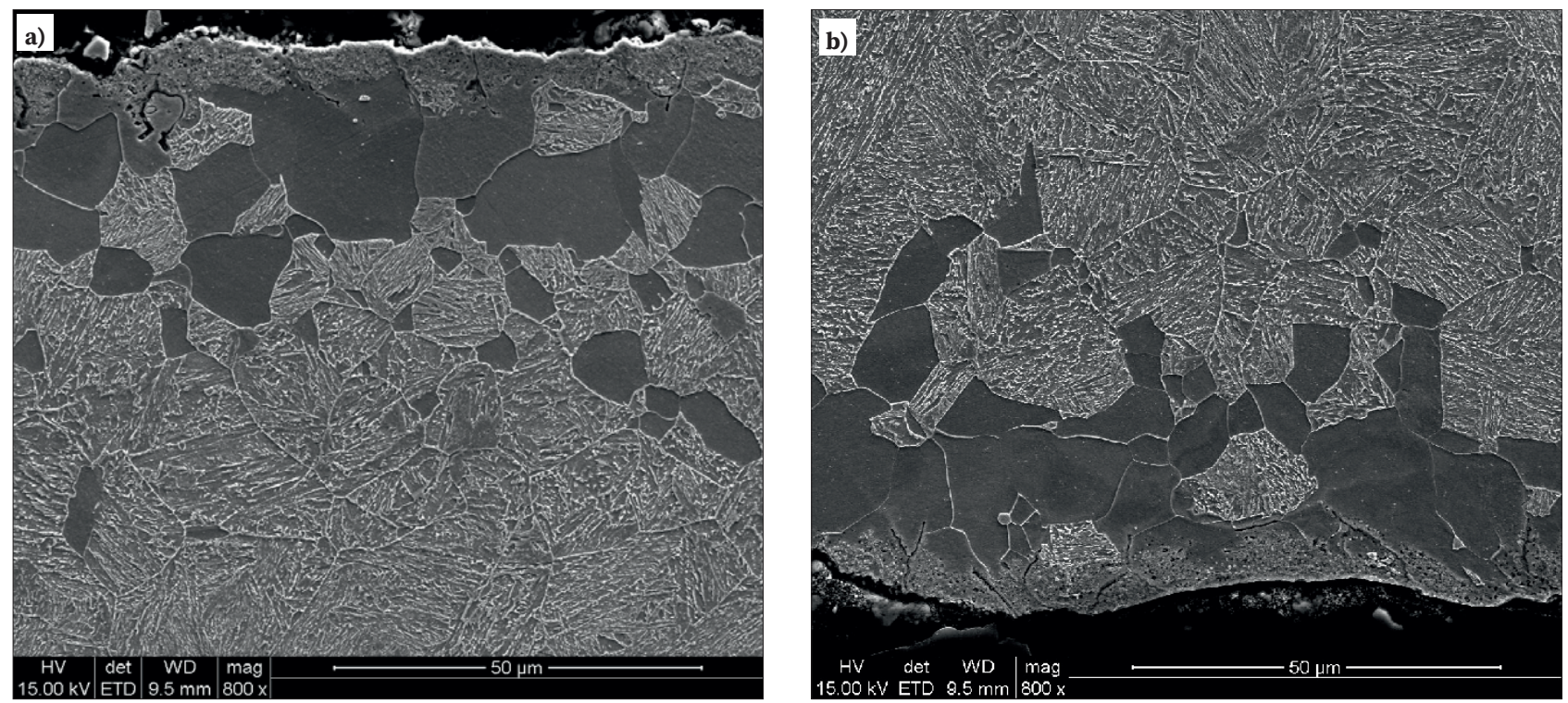

Fig. 25. SEM images covering the subsurface of the P2 steel plate heat-treated in industrial conditions

Rys. 25. Obrazy SEM obejmujące brzegi blachy ze stali P2 obrobionej cieplnie w warunkach przemysłowych

of $6.8 \mathrm{~mm}$ is approx. $0.5 \mathrm{~mm}$. The microhardness diagram in Fig. 26 also shows the fluctuation of properties on the plate's cross-section resulting from the influence of element segregation. In the presented example, this causes the variability of the microhardness of the bands of approximately $\pm 10 \mathrm{HV}$ in relation to the average value.

\subsection{RESULTS OF EXAMINATION OF RETAINED AUSTENITE IN TEST SAMPLES AND PLATES HEAT- TREATED UNDER INDUSTRIAL CONDITIONS}

The measurement of the total retained austenite (RA) content and the amount, morphology, size distribution and distribution of blocky retained austenite (bRA) after industrial heat treatment including a two-stage bainite transformation were performed on tensile samples (on the gripping part) suspended in sets of plates. The method of EBSD was used in a scanning electron microscope to determine the content and morphological parameters of bRA.
The measurement was taken at a $5000 \times$ magnification with the use of a single measurement area of $22.79 \times 51.81 \mu \mathrm{m}$. The smallest size of bRA grains detectable using the SEMEBSD method was estimated at $0.15 \mu \mathrm{m}$. The segregation of elements, which was formed as a result of solidification and generally has the character of microsegregation, may appear in some places as a macrosegregation and has an influence on the heterogeneous distribution of RA grains and on the dispersion of the results of measurement of the content and morphology of RA.

The results of the measurement of the content, morphology and size distribution of retained austenite grains lead to the following conclusions:

- The average total RA content (measured using the XRD method) in the test samples made of steel P1 is 19.1 vol\%, and in the test samples made of steel P2 it is 24.6 vol\%. In the samples from P2 steel plates heat-treated together with the test samples, an average of 23.7 vol\% of RA was obtained. 


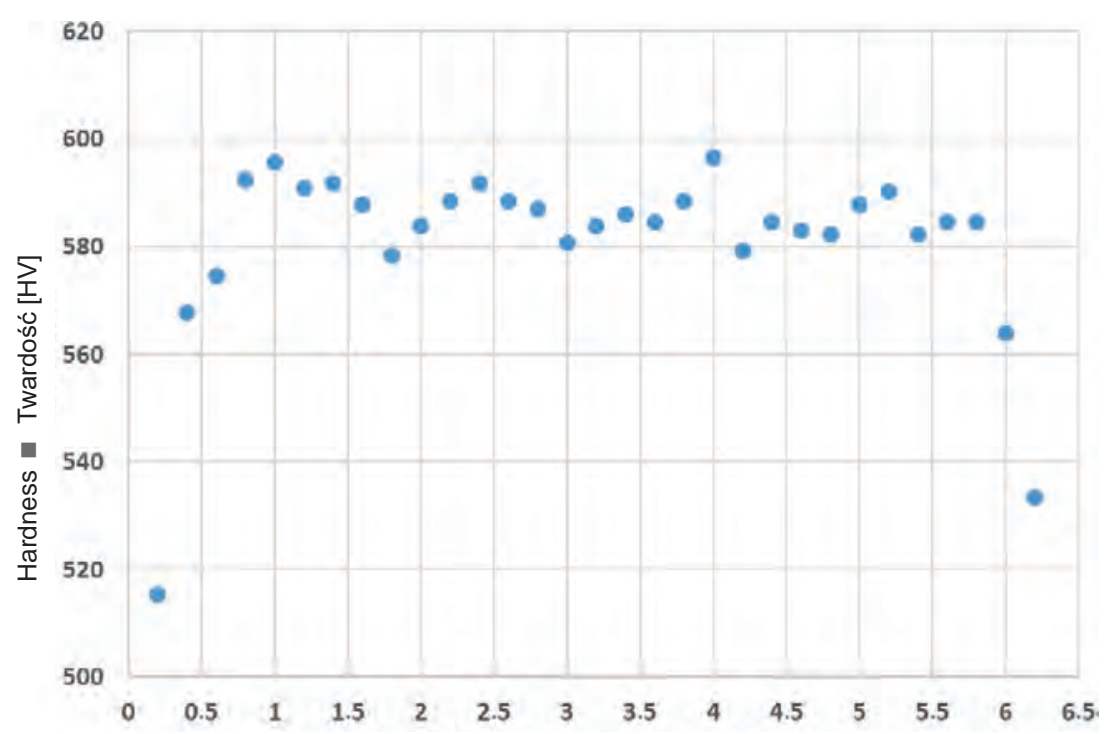

Distance from one of the steel plate surfaces $\square$ Odległość od jednej z powierzchni blachy [mm]

Fig. 26. Distribution of HV0.1 microhardness on the cross-section of $6.8 \mathrm{~mm}$ thick P2 steel plate heat-treated in industrial conditions Rys. 26. Rozkład mikrotwardości HV0,1 na przekroju blachy o grubości 6,8 mm ze stali P2 obrobionej cieplnie w warunkach przemysłowych

- The average content of blocky retained austenite bRA with grains larger than $0.15 \mu \mathrm{m}$ (measured using the EBSD method) in the test samples of steel $\mathrm{P} 1$ is 5.2 vol\% (in individual samples from $2.9 \%$ to $11.0 \%$ ), and in test samples made of the P2 steel it is 3.5 vol\% (in individual samples bRA $1.9 \%$ to $5.1 \%$ ). In the samples cut from plates heat-treated together with the test samples, an average of 8.7 vol\% of bRA (8.1 to 9.1\%) was obtained.

- Based on the EBSD analysis, average and maximum bRA grain sizes were determined; for test samples made of steel $\mathrm{P} 1$, the average value is $0.39 \mu \mathrm{m}$ and the maximum value is $1.13 \mu \mathrm{m}$, for test samples made of steel P2 the average value is $0.41 \mu \mathrm{m}$ and the maximum value is $1.10 \mu \mathrm{m}$, and for samples cut from heat-treated plates together with test samples the average value is $0.57 \mu \mathrm{m}$ and the maximum value is $1.63 \mu \mathrm{m}$.

The given quantitative characteristics of retained austenite in nanobainitic steel after two-stage treatment differ statistically significantly from those after one-stage treatment.

\subsection{ASSESSMENT OF THE EFFECTS OF TWO-STAGE TREATMENT}

The mechanical properties of nanobainitic steel, in particular the resistance to impact, largely depend on the content, morphology, uniformity of distribution and dimensions of grains, lamellae and laths of retained austenite. Based on the laboratory tests carried out in this project, it was found that the final heat treatment leading to the production of a nanobainitic steel matrix, carried out in stages successively at two temperatures with a strictly defined holding time at each of these temperatures, leads to the formation of a microstructure containing blocky retained austenite with more favourable morphological parameters - a larger population of bRA grains with a smaller size and a smaller size of the largest regions of bRA was obtained. This regularity is illustrated by the comparison of the grain size distribution of bRA in P1 and P2 steel samples processed in laboratory conditions with the use of single-stage
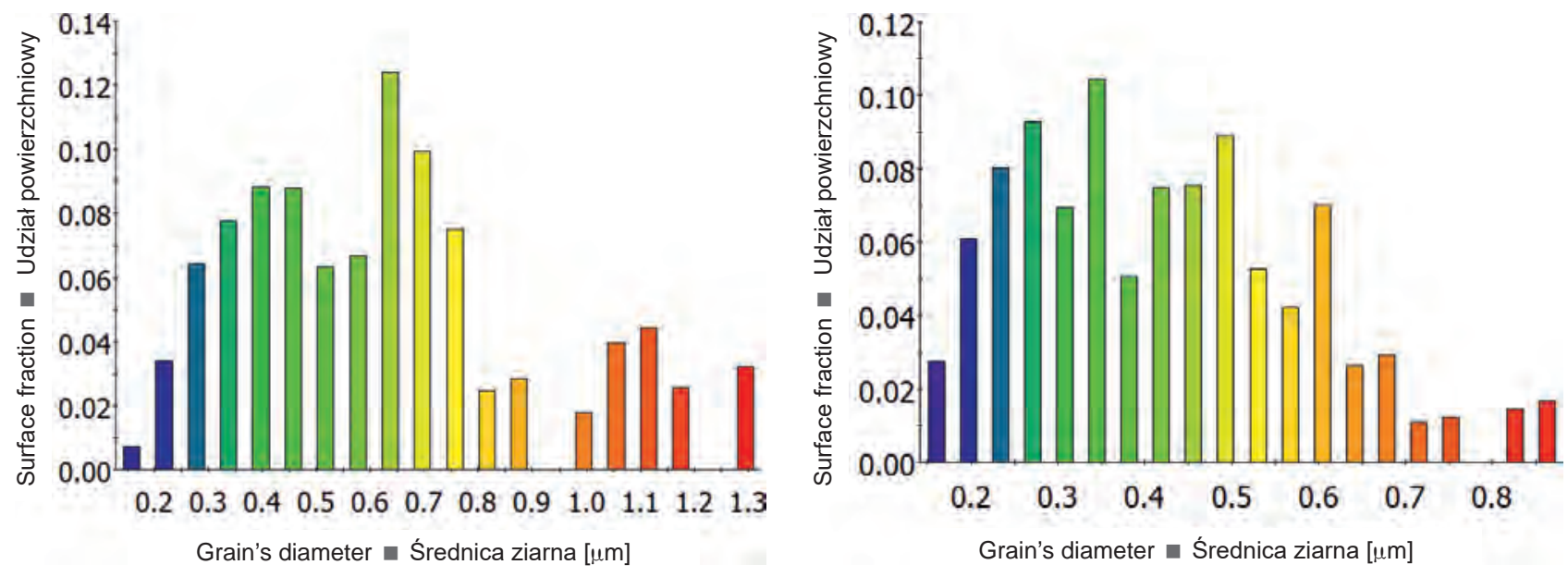

Fig. 27. Distribution of bRA grain sizes based on EBSD analysis in P1 steel samples after laboratory heat treatment: a) one-stage treatment: $210^{\circ} \mathrm{C} / 96 \mathrm{~h}$, average bRA grain diameter $\left.0.41 \mu \mathrm{m}, \mathrm{b}\right)$ two-stage treatment: $225^{\circ} \mathrm{C} / 12 \mathrm{~h}+1 \mathrm{~h}+210^{\circ} \mathrm{C} / 83 \mathrm{~h}$, grain diameter of bRA $0.30 \mu \mathrm{m}$

Rys. 27. Rozkład wielkości ziarn ARb na podstawie analizy EBSD w próbkach ze stali P1 po laboratoryjnej obróbce cieplnej: a) obróbka jednoetapowa: $210^{\circ} \mathrm{C} / 96$ godz., średnia średnica ziarna $\mathrm{ARb} 0,41 \mu \mathrm{m}$, b) obróbka dwuetapowa: $225^{\circ} \mathrm{C} / 12$ godz. +1 godz. $+210^{\circ} \mathrm{C} / 83$ godz., średnia średnica ziarna ARb $0,30 \mu \mathrm{m}$ 

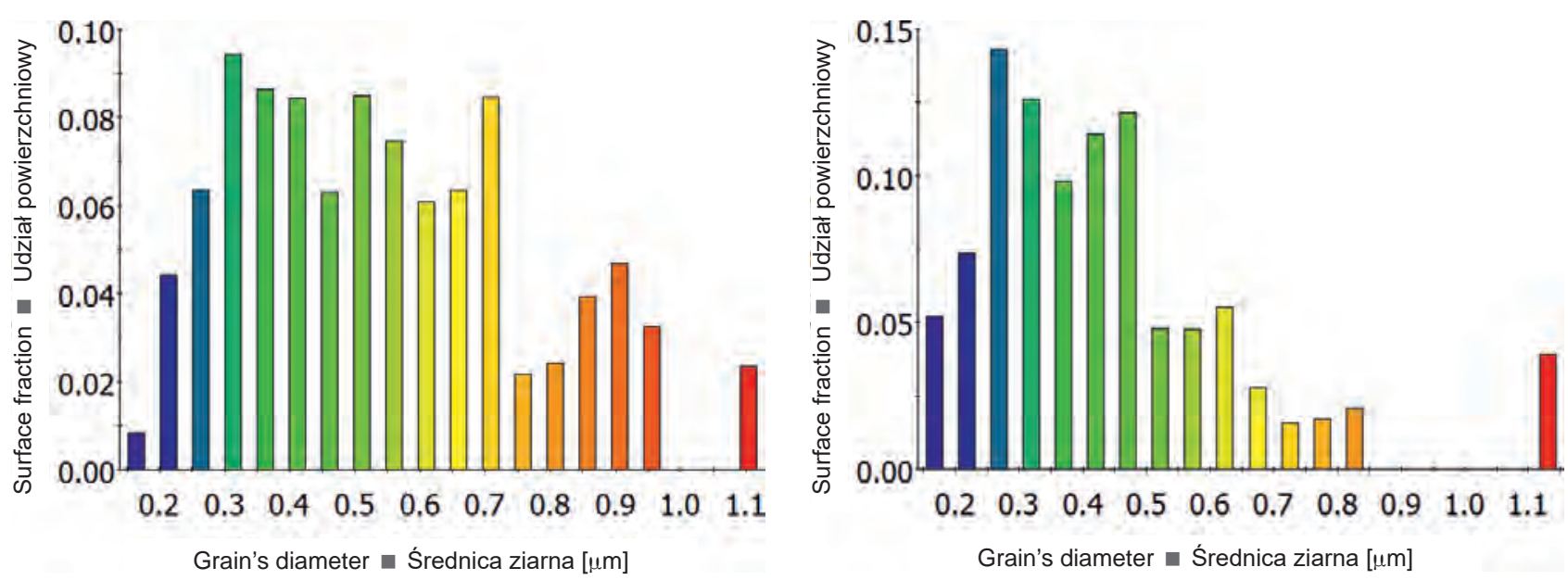

Fig. 28. Distribution of bRA grain sizes based on EBSD analysis in P2 steel samples after laboratory heat treatment: a) one-stage treatment at $210^{\circ} \mathrm{C}$ for 96 hours, average bRA grain diameter $0.37 \mu \mathrm{m}, \mathrm{b}$ ) two-stage treatment $225^{\circ} \mathrm{C} / 12 \mathrm{hours}+1 \mathrm{~h}+210^{\circ} \mathrm{C} / 83 \mathrm{hours}$, average bRA grain diameter $0.30 \mu \mathrm{m}$

Rys. 28. Rozkład wielkości ziarn ARb na podstawie analizy EBSD w próbkach ze stali P2 po laboratoryjnej obróbce cieplnej: a) obróbka jednoetapowa $w 210^{\circ} \mathrm{C}$ w ciąu 96 godzin, średnia średnica ziarna $\mathrm{ARb} 0,37 \mu \mathrm{m}, \mathrm{b}$ ) obróbka dwuetapowa $225^{\circ} \mathrm{C} / 12 \mathrm{godz} .+1 \mathrm{godz} .+210^{\circ} \mathrm{C} / 83$ godz. średnia średnica ziarna ARb 0,30 $\mu \mathrm{m}$

annealing (Figs. 27a and 28a) with two-stage annealing (Figs. 27b and 28b). An additional effect of the two-stage treatment is the increase in the total amount of RA in relation to the one-stage treatment, for P1 and P2 steels on average from $15-17$ vol\% to $21-24$ vol\%. As a result of the two-stage treatment in industrial conditions, the distribution of bRA grains with similar characteristics as in Figs. $27 \mathrm{~b}$ and $28 \mathrm{~b}$ was found, which confirms the adequate effect of the two-stage treatment on the grain refinement of the bRA phase.

\subsection{MEASUREMENT RESULTS FOR MECHANICAL PROPERTIES OF HEAT-TREATED PLATES UNDER INDUSTRIAL CONDITIONS}

Witness samples were attached to plates processed under industrial conditions. The results of the measurement of mechanical properties of witness samples are presented in Table 15. The required mechanical properties were achieved, which confirmed the correctness of the process. In the vast majority of cases, the assumed mechanical properties determined in the static tensile test were achieved. Single slight deviations from the requirements may result from the specific location of the samples in extremely unfavourable places of the plate set (e.g. in the corner area of the plate) and from a significantly smaller sample weight in relation to the plate's weight.

\subsection{RESULTS OF IMPACT STRENGTH MEASUREMENT FOR SAMPLES AFTER TWO-STAGE HEAT TREATMENT}

The results of impact strength measurement are presented in Table 16. The achieved impact energy values were converted to a standard sample width of $10 \mathrm{~mm}$. The nanobainitic steel in the P1 variant, after treatment with $225 / 12+210 / 84$, obtained the impact strength values of approx. $19 \mathrm{~J}$ and $11 \mathrm{~J}$ at +23 and $-40^{\circ} \mathrm{C}$, respectively. Slightly higher impact strength values were obtained for the P2 heat, which for the same heat treatment parameters amounted to approx. $21 \mathrm{~J}$ and $15 \mathrm{~J}$, respectively at +23 and $-40^{\circ} \mathrm{C}$. The high level of impact strength, especially at $-40^{\circ} \mathrm{C}$ - defined in the standards as a minimum of $12 \mathrm{~J}$ for a Char-
py-V sample, ensures the resistance of the tested steel grades to cracking under impact loads. Impact strength values similar to those achieved in the project are required for martensitic steels widely used in ballistic shields.

\subsection{FIRING TEST RESULTS FOR PLATES PRODUCED IN A FULL PRODUCTION CYCLE UNDER INDUSTRIAL CONDITIONS}

Firing tests were carried out for the plates' nominal thickness of $8.0 \mathrm{~mm}$ for the armour of the container's walls and for plates with a nominal thickness of $6.0 \mathrm{~mm}$ for the container's roof armour. The test result confirmed the achievement of the assumed protection level of the container's wall and roof models. Typical photographs of the plates after firing are presented in Fig. 29. The results of the firing tests showed the high potential of plates with the designed mechanical properties and thickness to meet the requirements of resistance to perforation in accordance with Stanag 4569 Level 2. In the mass plate production process, special attention should be paid to ensuring the uniformity of the chemical composition and properties on the surface and in the volume of a single plate. The results of firing tests indicated the necessity to strictly control the parameters at individual stages of production - from melting and casting, through processing, to the final heat treatment - in order to meet the protection requirements.

\section{SUMMARY}

Based on the tests of the material produced in laboratory conditions, the chemical composition of two grades of nanostructured bainitic steel was developed and guidelines for the following stages of industrial plate production: melting and casting, heat treatment of ingots before forging and slabs after forging, critical cooling rates and required temperature values during the process of rolling and immediately after rolling the plates. The material characteristics of industrial heats of two grades of nanobainitic steel were developed on the basis of dilatometric tests, measurement of mechanical properties and the volume 
Table 15. Results of measurement of mechanical properties. Witness samples attached to plates during heat treatment in a test cycle Tabela 15. Wyniki pomiarów właściwości mechanicznych. Próbki wytrzymałościowe „świadek” przymocowane do arkuszy blach w trakcie obróbki cieplnej w cyklu testowym

\begin{tabular}{|c|c|c|c|c|c|c|c|}
\hline \multicolumn{2}{|c|}{$\begin{array}{c}\text { Sample } \\
\text { identification }\end{array}$} & Location of sample in a plate set & $\begin{array}{c}\text { YS } \\
{[\mathrm{MPa}]}\end{array}$ & $\begin{array}{c}T S \\
{[\mathrm{MPa}]}\end{array}$ & $\begin{array}{c}T E \\
{[\%]}\end{array}$ & $\begin{array}{l}U E^{*} \\
{[\%]}\end{array}$ & TS/YS \\
\hline \multirow{8}{*}{$\begin{array}{l}\vec{ه} \\
\frac{0}{0} \\
\overrightarrow{0}\end{array}$} & P1.1.1 & $\begin{array}{l}\text { Centre of plate } 1 \\
\text { (first plate in the set from the furnace loading side) }\end{array}$ & 1370 & 2070 & 10.0 & 6.1 & 1.52 \\
\hline & P2.1.1 & $\begin{array}{l}\text { Centre of plate } 1 \\
\text { (first plate in the set from the furnace loading side) }\end{array}$ & 1302 & 2050 & 11.2 & 8.7 & 1.56 \\
\hline & P1.1.2 & $\begin{array}{l}\text { Lower corner of plate } 3 \text { (third plate in the set from the furnace } \\
\text { loading side) }\end{array}$ & 1519 & 1997 & 12.2 & 8.7 & 1.32 \\
\hline & P2.1.2 & $\begin{array}{l}\text { Lower corner of plate } 3 \text { (third plate in the set from the furnace } \\
\text { loading side) }\end{array}$ & 1332 & 1973 & 13.8 & 6.7 & 1.52 \\
\hline & P1.1.3 & $\begin{array}{l}\text { Centre of plate } 3 \\
\text { (third plate in the set from the furnace loading side) }\end{array}$ & 1468 & 2067 & 13.4 & 8.0 & 1.41 \\
\hline & P2.1.3 & $\begin{array}{l}\text { Centre of plate } 3 \\
\text { (third plate in the set from the furnace loading side) }\end{array}$ & 1323 & 2048 & 14.6 & 10.0 & 1.54 \\
\hline & P1.1.4 & Centre of plate 5 (central plate in the set) & 1506 & 2086 & 13.0 & 8.4 & 1.39 \\
\hline & P2.1.4 & Centre of plate 5 (central plate in the set) & 1318 & 2053 & 12.0 & 9.1 & 1.56 \\
\hline \multirow{4}{*}{$\begin{array}{l}\mathcal{N} \\
\frac{o}{J} \\
心 \\
心\end{array}$} & P1.2.1 & $\begin{array}{l}\text { Centre of plate } 9 \\
\text { (last plate in the set from the furnace loading side) }\end{array}$ & 1494 & 2075 & 12.2 & 7.7 & 1.39 \\
\hline & P2.2.1 & $\begin{array}{l}\text { Centre of plate } 9 \\
\text { (last plate in the set from the furnace loading side) }\end{array}$ & 1359 & 2063 & 12.4 & 9.7 & 1.52 \\
\hline & $\mathrm{P} 1.2 .5$ & Centre of plate 5 (central plate in the set) & 1308 & 2048 & 11.4 & 7.5 & 1.56 \\
\hline & P2.2.5 & Centre of plate 5 (central plate in the set) & 1499 & 2040 & 13.4 & 8.4 & 1.37 \\
\hline \multirow{4}{*}{ 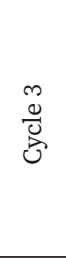 } & P1.3.1 & Centre of plate 5 (central plate in the set) & 1444 & 2034 & 11.8 & 8.2 & 1.41 \\
\hline & P2.3.1 & Centre of plate 5 (central plate in the set) & 1376 & 2011 & 12.6 & 8.8 & 1.47 \\
\hline & P1.3.2 & $\begin{array}{l}\text { Centre of plate } 9 \\
\text { (last plate in the set from the furnace loading side) }\end{array}$ & 1495 & 2028 & 10.4 & 6.6 & 1.35 \\
\hline & P2.3.2 & $\begin{array}{l}\text { Centre of plate } 9 \\
\text { (last plate in the set from the furnace loading side) }\end{array}$ & 1369 & 2007 & 11.6 & 7.5 & 1.47 \\
\hline \multirow{4}{*}{$\begin{array}{l}\stackrel{+}{0} \\
\stackrel{\Xi}{\Xi} \\
\vec{b}\end{array}$} & P1.4.1 & Centre of plate 5 (central plate in the set) & 1431 & 2080 & 14.0 & 9.0 & 1.45 \\
\hline & P2.4.1 & Centre of plate 5 (central plate in the set) & 1379 & 2060 & 12.6 & 9.9 & 1.49 \\
\hline & P1.4.2 & $\begin{array}{l}\text { Centre of plate } 9 \\
\text { (last plate in the set from the furnace loading side) }\end{array}$ & 1425 & 2051 & 13.0 & 8.5 & 1.45 \\
\hline & P2.4.2 & $\begin{array}{l}\text { Centre of plate } 9 \\
\text { (last plate in the set from the furnace loading side) }\end{array}$ & 1330 & 2040 & 12.8 & 8.5 & 1.54 \\
\hline \multirow{8}{*}{$\begin{array}{l}n \\
0 \\
0 \\
0 \\
0\end{array}$} & P1.5.1 & $\begin{array}{l}\text { Centre of plate } 1 \\
\text { (first plate in the set from the furnace loading side) }\end{array}$ & 1459 & 1992 & 12.0 & 8.2 & 1.37 \\
\hline & P2.5.1 & $\begin{array}{l}\text { Centre of plate } 1 \\
\text { (first plate in the set from the furnace loading side) }\end{array}$ & 1382 & 1968 & 13.1 & 9.2 & 1.43 \\
\hline & P1.5.2 & Centre of plate 5 (central plate in the set) & 1396 & 2002 & 12.0 & 7.1 & 1.43 \\
\hline & P2.5.2 & Centre of plate 5 (central plate in the set) & 1384 & 2008 & 11.8 & 7.2 & 1.45 \\
\hline & P1.5.3 & $\begin{array}{l}\text { Upper corner of plate } 7 \text { (seventh plate in the set from the furnace } \\
\text { loading side) }\end{array}$ & 1372 & 2034 & 12.9 & 8.7 & 1.49 \\
\hline & P2.5.3 & $\begin{array}{l}\text { Upper corner of plate } 7 \text { (seventh plate in the set from the furnace } \\
\text { loading side) }\end{array}$ & 1320 & 2016 & 13.1 & 8.9 & 1.54 \\
\hline & P1.5.4 & $\begin{array}{l}\text { Centre of plate } 7 \\
\text { (seventh plate in the set from the furnace loading side) }\end{array}$ & 1401 & 2008 & 13.1 & 8.7 & 1.43 \\
\hline & P2.5.4 & $\begin{array}{l}\text { Centre of plate } 7 \\
\text { (seventh plate in the set from the furnace loading side) }\end{array}$ & 1348 & 1993 & 13.8 & 9.0 & 1.47 \\
\hline
\end{tabular}

*UE - unform elongation

fraction of retained austenite, including microstructure examination in terms of the content of blocky and nanolathy austenite. The main results of research and tests of plates made from the developed steel grades intended for the armour of the observation and protective container are presented below.

- The following mechanical properties assumed to be achieved: $T S>2.0 \mathrm{GPa}, Y S>1.3 \mathrm{GPa}, \mathrm{TE}>12 \%$, were 
Table 16. Results of Charpy-V impact strength $\left(\mathrm{KV}_{2}\right)$ measurement for material after two-stage heat treatment Tabela 16. Wyniki pomiarów udarności Charpy-V (KV2) materiału po dwuetapowej obróbce cieplnej

\begin{tabular}{|c|c|c|c|c|c|c|}
\hline $\begin{array}{l}\text { Variant identification/ } \\
\text { sample No. }\end{array}$ & $\begin{array}{l}\text { Sample width } \\
{[\mathrm{mm}]}\end{array}$ & $\begin{array}{c}\text { Sample height } \\
{[\mathrm{mm}]}\end{array}$ & $\begin{array}{l}\text { Height below } \\
\text { notch } \\
{[\mathrm{mm}]}\end{array}$ & $\begin{array}{c}\text { Test } \\
\text { temp. } \\
T,\left[{ }^{\circ} \mathbf{C}\right]\end{array}$ & $\begin{array}{c}\text { Impact } \\
\text { energy } \\
{[\mathrm{J}]}\end{array}$ & $\begin{array}{c}\text { Impact energy } \\
\text { converted per sample } \\
10 \times 10 \times 55 \mathrm{~mm} \\
{[\mathrm{~J}]}\end{array}$ \\
\hline P1.225.12_210.84/1 & 7.47 & 9.93 & $(7.93)$ & 23 & 14 & 19 \\
\hline$/ 2$ & 7.45 & 9.95 & $(7.94)$ & 23 & 14 & 19 \\
\hline$/ 3$ & 7.42 & 9.94 & $(8.07)$ & 23 & 15 & 20 \\
\hline 14 & 7.47 & 9.93 & $(7.94)$ & -40 & 8 & 11 \\
\hline$/ 5$ & 7.45 & 9.95 & $(7.93)$ & -40 & 8 & 11 \\
\hline 16 & 7.46 & 9.94 & $(7.94)$ & -40 & 10 & 13 \\
\hline P2.225.12_210.84/1 & 7.47 & 9.93 & $(7.87)$ & 23 & 16 & 21 \\
\hline$/ 2$ & 7.45 & 9.95 & $(7.96)$ & 23 & 18 & 24 \\
\hline$/ 3$ & 7.46 & 9.94 & (7.93) & 23 & 16 & 21 \\
\hline 14 & 7.47 & 9.93 & $(7.93)$ & -40 & 9 & 12 \\
\hline 15 & 7.45 & 9.95 & $(8.07)$ & -40 & 11 & 15 \\
\hline 16 & 7.46 & 9.94 & $(8.06)$ & -40 & 11 & 15 \\
\hline
\end{tabular}

met (or reached the level very close to the required values) by $79 \%$ of the test samples, while a few samples, to a relatively small extent, did not meet the established minimum levels of mechanical performance. No case was found that would disqualify the material in terms of the level of mechanical properties. This result should be considered very good for the first batches of plates heat-treated under industrial conditions. The average values of parameters determined in a tensile test for all test samples are:

- for steel P1: TS = $2041 \mathrm{MPa}, Y S=1435 \mathrm{MPa}, T E=12.2 \%$, - for steel P2: TS $=2024 \mathrm{MPa}, Y S=1359 \mathrm{MPa}, T E=12.8 \%$.

- The correct type of plate's microstructure was obtained for all tested variants of heat treatment - with small deviations unavoidable in the industrial process, i.e. the matrix is nanobainite, and the remaining phase components are retained austenite in blocky form and - in some variants - traces of plate or lath martensite. Attention is paid to the influence of primary segregation and the resulting microstructure banding, which at a certain intensity (difference in the content of key elements, i.e.
Mo, Mn, Si and Cr in adjacent bands) can significantly change the functional properties of the material locally.

- The final treatment leading to the production of a nanobainitic steel matrix, carried out successively at two temperatures with a strictly defined holding time at each of these temperatures $(225 / 12+210 / 84)$, leads to the formation of a microstructure containing blocky retained austenite with favourable morphological parametersa large population of bRA grains with a smaller size and a smaller size of the largest regions of bRA was obtained. An additional effect of the two-stage treatment is the increase in the total volume fraction of RA in relation to the one-stage treatment, for P1 and P2 steels on average from $15-17$ vol\% to $21-24$ vol\%. The arrangement, morphology and size distribution of grains and laths of retained austenite are strongly dependent on the microsegregation of elements. The occurrence of segregation areas, especially with increased Mo content, was found, in which the estimated content and size of blocky austenite grains were larger compared to the areas of bands depleted in alloying elements.
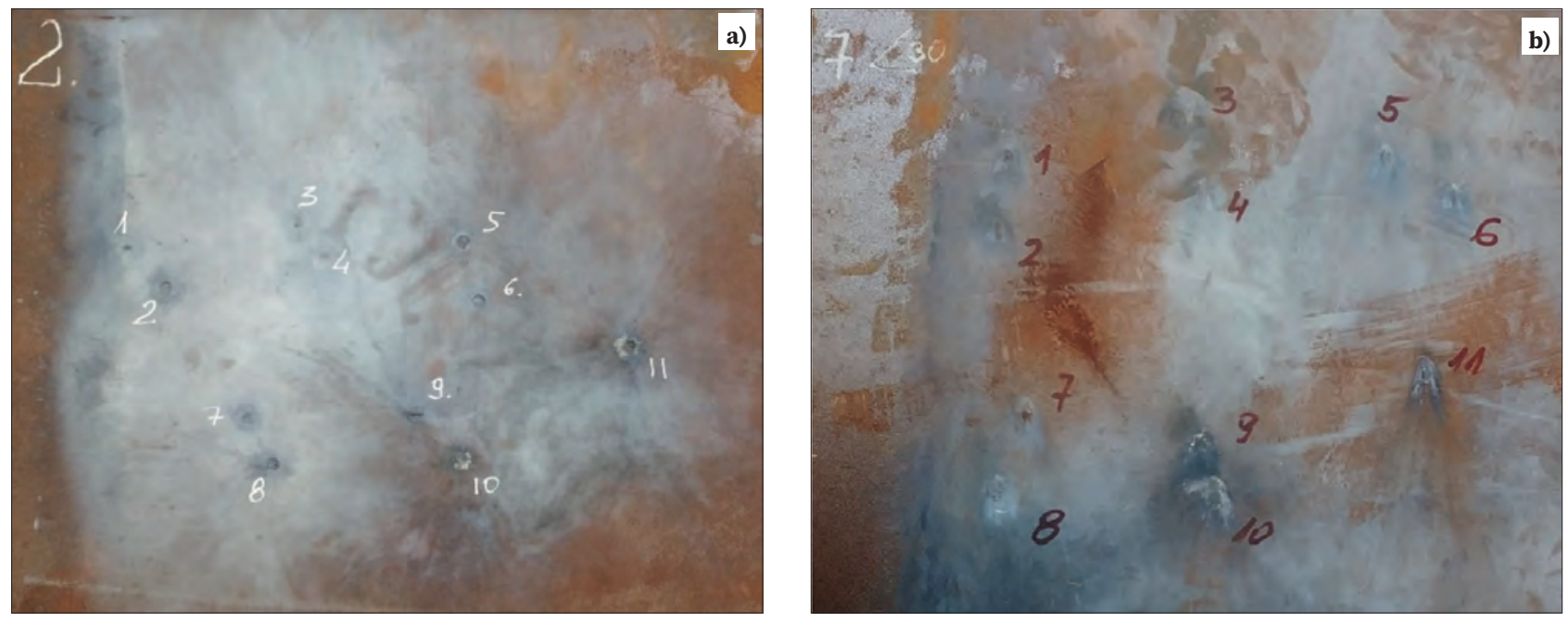

Fig. 29. Plates after firing. a) heat P2, thickness $8.0 \mathrm{~mm}$; b) heat P1, thickness $7.0 \mathrm{~mm}$

Rys. 29. Fotografia blach po ostrzale. a) wytop P2, grubość 8,0 mm; b) wytop P1, grubość 7,0 mm 
- Nanobainitic steel - P1 heat, after treatment 225/12 + 210/84, obtained impact strength values of approx. $19 \mathrm{~J}$ and $11 \mathrm{~J}$ at +23 and $-40^{\circ} \mathrm{C}$, respectively. Higher impact strength values were obtained for the P2 heat steel, which for the same HT parameters amounted to approx. $21 \mathrm{~J}$ and $15 \mathrm{~J}$, respectively at +23 and $-40^{\circ} \mathrm{C}$. Similar impact strength values are required for quenched and tempered martensitic steels widely used in ballistic shields.

The results of the firing tests showed the high potential of plates with the designed mechanical properties and thickness to meet the requirements of resistance to perforation in accordance with Stanag 4569 Level 2. In the mass plate production process, special attention should be paid to ensuring the uniformity of the chemical composition and properties on the surface and in the volume of a single plate. The results of firing tests indicated the necessity to strictly control the parameters at individual stages of production - from melting and casting, through processing, to the final heat treatment - in order to meet the requirements for ballistic protection.
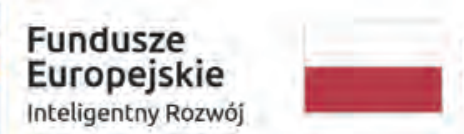

Rzeczpospolita Polska

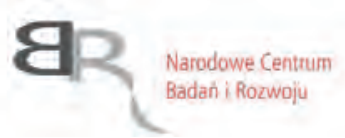
Unia Europejska
Europejski Fundusz
Rozwoju Regionalnego

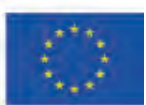

This work was financially supported by the National Centre for Research and Development (POIR-04.01.04-000047/16, Project "Development of production technology of light observation and protective container (LOOK) made of nanostructured ultrastrength steels").

\section{REFERENCES}

[1] H.K.D.H. Bhadeshia, D.V. Edmonds. The bainite transformation in a silicon steel. Metallurgical Transactions A, 1979, 10A, pp. 895-907.

[2] H.K.D.H. Bhadeshia. Thermodynamic analysis of isothermal transformation diagrams. Metal Science, 1982, 16 (3), pp. 159-165.

[3] H.K.D.H. Bhadeshia, D.V. Edmonds. Bainite in silicon steels: new composition; property approach Part 1. Metal Science, 1983, 17 (9), pp. 411-419.

[4] H.K.D.H. Bhadeshia, J.W. Christian. Bainite in steels. Metallurgical Transactions A, 1990, 21 (3), pp. 767-797.

[5] H.K.D.H. Bhadeshia. Bulk nanocrystalline steel. Ironmaking \& Steelmaking, 2005, 32 (5), pp. 405-410.

[6] H.K.D.H. Bhadeshia, P. Brown, C. Garcia-Mateo. Bainite steel and methods of manufacture therof. Patent GB2462197, 2010.

[7] L. Wenyan, Q. Jingxin, S. Hersheng. Fatigue crack growth behaviour of a Si-Mn steel with carbide-free lathy bainite. Journal of Materials Science, 1997, 32, pp. 427-430.

[8] F.G. Caballero, H.K.D.H. Bhadeshia, K.J.A. Mawella, D.G. Jones, P. Brown. Very strong low temperature bainite. Materials Science and Technology, 2002, 18, pp. 279-284.

[9] C. Garcia-Mateo, F.G. Caballero and H. K. D. H. Bhadeshia. Development of hard bainite. ISIJ International, 2003, 43 (8), pp. 12381243.

[10] M.N. Yoozbashi, S. Yazdani. Mechanical properties of nanostructured, low temperature bainitic steel designed using a thermodynamic model. Materials Science and Engineering A, 2010, 527, pp. 3200-3205.

[11] B. Garbarz, B. Niżnik-Harańczyk. Modification of microstructure to increase impact toughness of nanostructured bainite-austenite steel. Materials Science and Technology, 2015, 31 (7), pp. 773-780.
[12] B. Garbarz, W. Burian. Microstructure and properties of nanoduplex bainite-austenite steel for ultra-high-strength plates. Steel Research int., 2014, 85 (12), pp. 1620-1628.

[13] B. Garbarz, W. Zalecki. Kinetyka izotermicznych przemian fazowych poniżej temperatury $M_{s}$ w ultra wysokowytrzymałych stalach konstrukcyjnych. Prace Instytutu Metalurgii Żelaza, 2017, 69 (1), pp. 2-9.

[14] J. Saragosa. Design and characterization of a carbide-free nanoscale bainite alloy, Praca magisterska, McMaster University, 2015.

[15] B. Garbarz, J. Marcisz, W. Burian. Technological peculiarities of manufacturing nanobainitic steel plates. In: METEC, Düsseldorf, Germany, 15-19 czerwca 2015, pp. 1-9.

[16] B. Garbarz, et al. Technologia wytwarzania supertwardych materiałów nanostrukturalnych ze stopów żelaza oraz ich zastosowanie w pancerzach pasywnych i pasywno-reaktywnych, 2009-2013, [unpublished].

[17] IMŻ patent based on patent application No. 394037 (UP RP) of 25.02.2011: Bainitic and austenitic steel and the method of producing panels from this steel; IMŻ patent application No. P. 396431 (UP RP) of 26.09.2011: Heat treatment methods for bainitic and austenitic steel; IMŻ patent application No. P.407091 (UP RP) of 6.02.2014: Sposób obróbki cieplnej wyrobów z ultrawytrzymatej stali średniostopowej.

[18] J. Marcisz, et al. Opracowanie nowoczesnej konstrukcji modułu pancerza odpornego na udarowe oddziaływanie strumienia kumulacyjnego i pocisków, 2012-2015. [unpublished].

[19] S. Pashangeh, H.R.K. Zarchi, S.S.G. Banadkouki, M.C. Somani. Detection and Estimation of Retained Austenite in a High Strength Si-Bearing Bainite-Martensite-Retained Austenite Micro-Composite Steel after Quenching and Bainitic Holding (Q\&B). Metals 2019, 9, pp. 492. 